\title{
Wilma Allemandi
}

Estudo da imunorreatividade da proteína $S 100 \beta$ no Hipocampo e Núcleo do Trato Solitário de ratos neonatos submetido à anóxia

Tese apresentada ao Programa de PósGraduação em Ciências Morfofuncionais do Instituto de Ciências Biomédicas da Universidade de São Paulo, para obtenção do Título de Doutor em Ciências. 


\section{Wilma Allemandi}

Estudo da imunorreatividade da proteína $S 100 \beta$ no Hipocampo e Núcleo do Trato Solitário de ratos neonatos submetido à anóxia

Tese apresentada ao Programa de PósGraduação em Ciências Morfofuncionais do Instituto de Ciências Biomédicas da Universidade de São Paulo, para obtenção do Título de Doutor em Ciências.

Área de concentração: Ciências Morfofuncionais

Orientadora: Prof. Dr. Maria Inês Nogueira

Versão corrigida: a Versão original encontra-se arquivada no Setor de Comunicação do ICB

SÃO PAULO

2011 


\section{DADOS DE CATALOGAÇÃO NA PUBLICAÇÃO (CIP)}

Serviço de Biblioteca e Informação Biomédica do

Instituto de Ciências Biomédicas da Universidade de São Paulo

reprodução não autorizada pelo autor

Allemandi, Wilma.

Estudo da imunorreatividade da proteína $S 100 \beta$ no hipocampo e núcleo do trato solitário de ratos neonatos submetidos à anóxia / Wilma Allemandi. -- São Paulo, 2011.

Orientador: Profa Dra. Maria Inês Nogueira.

Tese (Doutorado) - Universidade de São Paulo. Instituto de Ciências Biomédicas. Departamento de Anatomia. Área de concentração: Ciências Morfofuncionais. Linha de pesquisa: Sistemas neurais envolvidos em reflexos e ritmos biológicos: enfoque no sistema serotoninergico abordagem filo-ontogenética. Ensino e divulgação/ compreensão pública de ciências/neurociências: abordagem investigativa e interdisciplinar.

Versão do título para o inglês: Study of $S 100 \beta$ protein immunoreactivity in the hypocampus and nucleus of solitary tract of newborn rats submitted to anoxia.

Descritores: 1. Anóxia neonatal 2. Astrócitos 3. S100ß 4. GFAP 5. Western blot 6. Imunoistoquímica I. Nogueira, Profa Dra. Maria Inês II. Universidade de São Paulo. Instituto de Ciências Biomédicas. Programa de Pós-Graduação em Ciências Morfofuncionais III. Título. 
Candidato(a):

Título da Tese:

Orientador(a):
Wilma Allemandi.

Estudo da imunorreatividade da proteína $S 100 \beta$ no hipocampo e núcleo do trato solitário de ratos neonatos submetidos à anóxia.

A Comissão Julgadora dos trabalhos de Defesa da Tese de Doutorado, em sessão pública realizada a I................., considerou

\section{( ) Aprovado(a) ( ) Reprovado(a)}

Examinador(a): Nome completo:

Instituição:

Examinador(a): $\quad$ Nome completo:

Instituição:

Examinador(a): $\quad$ Nome completo:

Instituição:

Examinador(a): Nome completo:

Instituição:

Presidente: Nome completo:

Instituição: 


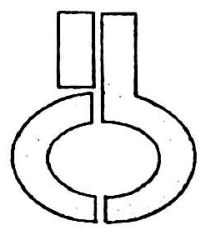

\section{UNIVERSIDADE DE SÃO PAULO INSTITUTO DE CIÊNCIAS BIOMÉDICAS}

Cidade Universitária "Armando de Salkes Oliveira"

Av. Prot. Lineu Prestes, 2415 - CEP. 05608-000 Săo Paulo, SP - Brasil

Telefone :(55) (011) 3091.7733 - telefax : (55) (011) 3091.7438

e-mail: cep@icb.usp.br

\section{Certificado}

Certificamos que o protocolo registrado sob $n^{\circ} 134$ nas fls. 38 do livro 2 para uso de animais em experimentaçāo, sob a responsabilidade de Maria Inès Nogueira, Coordenador(a) da Linha de pesquisa "Efeitos da anóxia neonatal no encéfalo de ratos: alterações morfológicas, expressão da proteina Fos e sua inter-relação com o sistema serotoninérgico" do qual participou(aram) o(s) alunos Silvia Honda Takada, Paula Hiromi Ito, Renata Gonçalves de Vasconcellos, está de acordo com os Princípios Éticos de Experimentação Animal adotado pelo Colégio Brasileiro de Experimentação Animal (COBEA) e foi aprovado pela COMISSĀO DE ÉTICA EM EXPERIMENTAÇĀO ANIMAL (CEEA) em 21.11.2006.

1

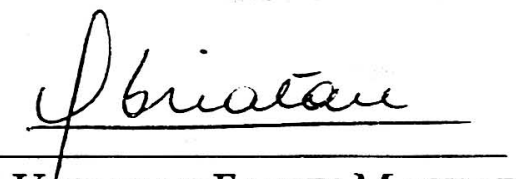

Prof. Dr. UßBRATAN FABRES MACHADO Coordenador da CEEA - ICB/USP
São Paulo, 22 de novembro de 2006.

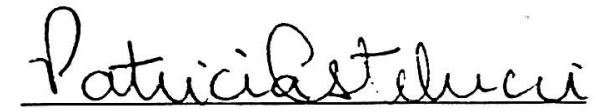

Profa. Dra. PATRÍcia CASTEluCCI Secretária da CEEA - ICB/USP 


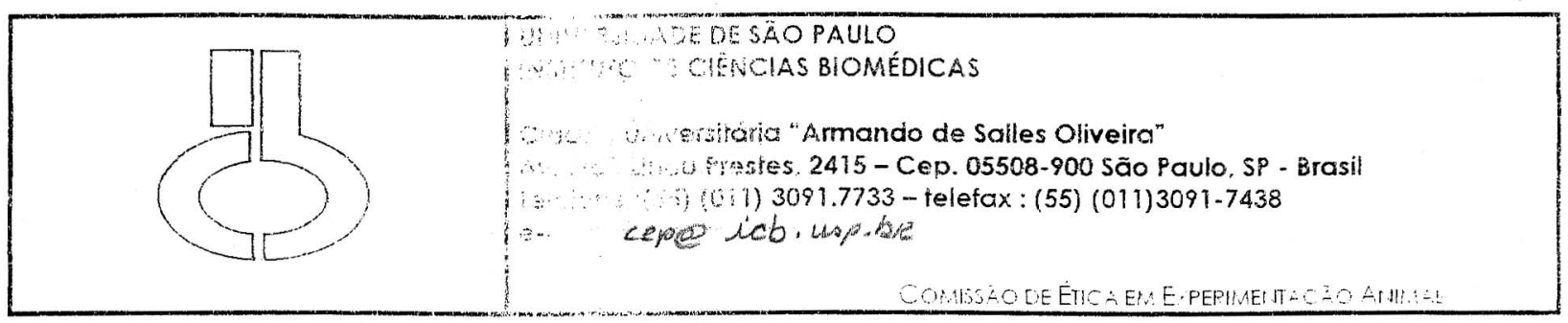

DECl. CEEA.039.08

DECLARAÇ $\tilde{A} O$

Em adendo ao Certificado 134/06/CEEA, datado de 21.11 .06 e por solicitação da Profa. Dra. Maria Inês Nogueira, responsável pela linha de Pesquisa, autorizo a inclusão da aluna WILMA ALLEMANDI ao projeto de pesquisa "Efeiros da anóxia neonatal no encéfalo de ratos: alterações morfológicas, expressão da proteína fos e sua inter-relação com o sistema serotoninérgico", uma vez que se trata de utilização da mesma espécie animal e de métodos experimentais similares ao referido certificado.

São Paulo, 21 de agosto de 2008.

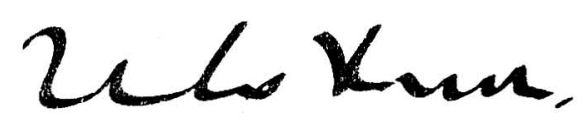

Prof. Dr. WOTHAN TAVARES DE LIMA

Coordenador-CEEA-ICB/USP 


\section{DEDICATÓRIA}

À minha amada família,

Sinto-me abençoada e privilegiada por ter vocês, meus amados e queridos, vocês são o perfume que a vida gratamente me doou, quando estou perto de vocês, minha mente e meu coração se tranqüiliza e se transforma. Vocês me ensinam a essência da vida, onde a tolerância, o amor, o respeito, deve ser uma constante na vida das pessoas. Obrigada por amar e ser amada, meus queridos... irmã, Sandra!, irmão, Roberto! Sobrinhos, Alessandra, Marcos, Ale e Enzo!

In Memmoriam, aos meus amados, pai e mãe......vocês devem estar sorrindo no céu,.... e aqui,..... eu estou chorando,..... de saudades!! e de alegria. Amo muito vocês! 


\section{DEDICATÓRIA}

A minha orientadora,

Profa. Dra. Maria Inês Nogueira, professora e amiga, nos legando o melhor de si, ora com toda sensibilidade de que dispõe um ser humano, ora como mestra querendo o melhor para seus alunos, brigando por eles e para eles. Com todo meu coração agradeço sua compreensão e de transformar meu sonho em......... nosso sonho. Obrigada. 
AGRADECIMENTOS ESPECIAIS

À amiga, e...

Querida Mestra Priscila de Abreu Rocha. Deus com certeza deixa na terra seres especiais, e eles se alimentam de Amor, jamais permitindo que falte algo a qualquer ser humano que esteja próximo a eles,.... são os Anjos...Obrigada, minha querida...você...é o meu anjo, você é parte de minhas emoções. 


\section{AGRADECIMENTOS ESPECIAIS}

Aos queridos Professores do Departamento de Anatomia do Instituto de Ciências Biomédicas da Universidade de São Paulo, "Obrigada". Sinto-me uma pessoa plenamente realizada por estar aqui, estudando e fazendo parte do corpo de estudantes de Pós-Graduação. Obrigada por cada gesto de carinho que todos sempre tiveram comigo, pois na solidão de uma pesquisa eu tive o conforto da presença dos senhores.

Ao Prof. Dr. Esem Cerqueira Pereira, do Departamento de Anatomia do Instituto de Ciências Biomédicas da Universidade de São Paulo, por ter-me dado oportunidade de estar aqui estudando, por seu carinho e constante incentivo, valorizando-me como ser humano.

Ao Prof. Dr. Edson Aparecido Liberti do Departamento de Anatomia do Instituto de Ciências Biomédicas da Universidade de São Paulo, é um privilégio tê-lo aqui junto aos Pós-Graduandos, pois de forma especial conduz tudo e a todos com Amor e Carinho. Sou-lhe imensamente grata, pois se tornou um exemplo de ser humano tornando nossa caminhada de alunos mais suave. Obrigada, Amigo. Os mesmos e verdadeiros sentimentos, à sua querida esposa, amiga e companheira Profa. Dra. Silvia Boldrini Liberti, in Memoriam, "Aos Mestres com Carinho".

A todos os amigos do Laboratório da Prof. M.Inês. Obrigada por descobrirem dia a dia o valor de um carinho, de uma amizade, da união, onde somente no calor das necessidades possibilitamos a percepção e a realização de transformações. Parabéns amigos! Pela luta pessoal, pelo crescimento individual, por vossas conquistas.

A todos os Amigos de outros Laboratórios deste Departamento, que sempre me trataram com muito carinho, com estima, em todos os momentos, em todos os lugares. Por mais que uma pesquisa seja individual, ela carece da Força dos Sentimentos Humanos. Obrigada meus queridos.

À belíssima equipe de funcionários da Biblioteca do Instituto de Ciências Biomédicas da Universidade de São Paulo, supervisionados pela Sra. Maria do Socorro Bezerra Rocha, Diretora Técnica e toda sua valorosa equipe. Agradeço a cada um de vocês, sempre me auxiliando com gentileza, carinho e profissionalismo.

Aos funcionários do Biotério e Bloco Didático do Departamento de Anatomia do Instituto de Ciências Biomédicas da Universidade de São Paulo. Amigos, vocês são de valor inestimável ao meu coração.

Aos Funcionários das Secretarias de Pós-Graduação e Graduação do Instituto de Ciências Biomédicas da Universidade de São Paulo, sempre especiais e profissionais a qualquer momento. 


\section{AGRADECIMENTOS}

Ao Departamento de Anatomia do Instituto de Ciências Biomédicas da Universidade de São Paulo, por todas as oportunidades que me foram concedidas para a realização desta dissertação no Curso de Pós-Graduação.

À Profa. Dra. Maria Luiza Morais Barreto de Chaves, coordenadora do Programa de Pós-Graduação do Departamento de Anatomia do Instituto de Ciências Biomédicas da Universidade de São Paulo, pelo constante apoio, incentivo e de forma sempre carinhosa nos prestigiando.

À Profa. Dra. Marucia Chacur do Departamento de Anatomia do Instituto de Ciências Biomédicas da Universidade de São Paulo, atenção, carinho, material, preocupação, confiança, acreditar, "foco"...e sua equipe amiga, maravilhosa, especial, são como verdadeiros "mosqueteiros" com o lema "Todos por um e um por todos"... Obrigada Priscila, Aline, Daniel, Fábio, Joyce, Mara, Milena, Regina. Amores vocês são especiais, minha profunda e sincera estima.

À Profa. Dra. Cecília H.A. Gouveia; Profa. Dra. Claudimara F.P. Lotfi; Prof. Dr. Edson A. Liberti; Profa. Dra. Elen H. Miyabara; Prof. Dr. li-Sei Watanabe; Prof. Dr. Esem Cerqueira Pereira; Prof. Dr. Jackson Cione Bittencourt; Profa. Dra. Maria Inês Nogueira; Profa. Dra. Maria Luiza M.B de Chaves; Profa. Dra. Marucia Chacur; Prof. Dr. Newton S. Canteras; Profa. Dra. Patrícia Castelucci; Profa. Dra. Silvia Lacchini; Prof. Dr. Renato Chopard; Prof. Dr. Richard Halti Cabral.

Aos Professores, obrigada por vosso amor, preocupações e dedicação por vossos alunos e por "agregados" como eu, por exemplo. Agradeço a gentileza de sempre me receberem bem, me auxiliando com material, com vossos aparelhos, com interesse constante de saber se estou bem e se a pesquisa está bem, e...queridos professores, vossos alunos são vossos espelhos em gentilezas, carinho, respeito, amor, amizade e solidariedade. Sinto-me plena em Alegria, Força e Coragem, pois cada um de vocês em "todos os pequenos grandes momentos" que por acaso estivéssemos juntos, transmitiram esses lindos sentimentos e transformaram meu lindo sonho em realidade. OBRIGADA QUERIDOS AMIGOS. A felicidade existe, desejo de todo meu coração que ela seja sempre companheira de cada um de vocês. Todo meu carinho.

A Sra. Cleide Rosana Duarte Prisco, responsável pelo setor de Estatística do Instituto de Ciências Biomédicas da Universidade de São Paulo. Que com profissionalismo transformou essa pesquisa em "nossa pesquisa". Obrigada amiga e querida do meu coração, você é como a luz do sol, mesmo que haja trevas aqui em baixo, ele continua brilhando e aquecendo corações.

A todos os Amigos Queridos do meu Laboratório de Neurociências do Departamento de Anatomia do Instituto de Ciências Biomédicas da Universidade de São Paulo, Barbara, Leila, Mike, Paula, Pinato, Renée, Roberto T., Silvia, Vanderlei, Vitor e Roberto, querido e bom amigo, assim como bom profissional técnico. A todos da Equipe de Educação e Ciências. 
Aos queridos Cleyton e Luciano, já em outros Departamentos. É com muita emoção que se faz esse parágrafo, este sempre sairá do coração por tanto tempo e momentos de vida em conjunto. Estou mais feliz hoje, pois consegui completar um estudo que sempre me fascinou, não importa resultados, mas lindo e difícil foi a caminhada, se ela por vezes se tornou amena e encantadora, com certeza foram momentos que vocês meus queridos me proporcionaram. Obrigada Amores, meu eterno carinho.

A Sra. Joelcimar, Técnica Especialista de Laboratório do Departamento de Anatomia do Instituto de Ciências Biomédicas da Universidade de São Paulo. Não houve um dia, um momento que você deixasse de me dar forças, coragem, confiança, alem de sua excelência profissional. Obrigada grande Amiga por cada rico momento.

A Sra. Amanda, Técnica Especialista de Laboratório do Departamento de Anatomia do Instituto de Ciências Biomédicas da Universidade de São Paulo, por inestimável ajuda em técnicas de laboratório, sempre que precisei.

A Sra. Patricia, à Sra. Cristiane e à Sra. Luciana da Secretaria do Departamento de Anatomia do Instituto de Ciências Biomédicas da Universidade de São Paulo. Sinto imensa gratidão por vocês, pela constante ajuda e presença, sempre nos auxiliando com muita paciência, profissionalismo e carinho. Amores, vocês sempre foram especiais, sempre torceram por mim, com todo meu coração, Obrigada.

À Equipe de Funcionários da Biblioteca do Instituto de Ciências Biomédicas da Universidade de São Paulo, Diretora Técnica, Maria do Socorro Bezerra, Delza, Edilson, Eva, Isabel, Jacinta, Juliana, Márcia, Maria do Socorro, Monica, Paulo, Renata, Rosa, Tereza, Valéria e Yoshi. Vocês pertencem a Equipe do meu coração, são como arvores frondosas que tem mil funções na vida, elas são lindas, protegem, nos dão alimento para o corpo e a alma. Obrigada queridas (os), por seu amor e carinho para comigo. Amo vocês.

Aos Funcionários da Secretaria de Pós-Graduação do Instituto de Ciências Biomédicas da Universidade de São Paulo, Sr. Celso Dias Pereira, Sra. Fabiana Barboza Correa, Sra. Edna Aparecida Prando, Sra. Luciana Vicente da Silva.

Aos funcionários do Biotério do Departamento de Anatomia do Instituto de Ciências Biomédicas da Universidade de São Paulo, Sr Alessandro Rodrigo Martins, Fábio, Renivaldo de Souza, Ricardo Bandeira. "Meninos de Ouro", gratidão e carinho é pouco, por todas incontáveis vezes que contribuíram para que esse projeto se concretizasse, com vosso profissionalismo, dedicação e carinho. Amo vocês.

Aos funcionários do Bloco Didático do Departamento de Anatomia do Instituto de Ciências Biomédicas da Universidade de São Paulo, Adevair Urenha Alves, Carlos Roberto Caldas, Edison Dantas da Silva, Everton Luis Pavan Correia, José Adão Mendes, Milton e ao Sr. Giovaldo Serafim Correia, por todos 
auxílios prestados sempre de forma carinhosa e profissional, durante todos esses anos nas aulas de Anatomia prática nos cursos dados à Graduação.

Aos Funcionários do Departamento de Anatomia do Instituto de Ciências Biomédicas da Universidade de São Paulo, José Ivan Moura Nogueira, José Abelírio de Oliveira, José Evangelista de Santana, Delman, José Carlos da Matta. Ao atual responsável Jose Carlos e toda sua Equipe, Celso, Aparecido, Rafael, meu carinho, pois todos fizeram verdadeiramente parte de minhas emoções, transformando meus momentos de pequenas tristezas em alegrias.

Aos queridos responsáveis por nosso prestimoso Museu de Anatomia do Departamento Anatomia do Instituto de Ciências Biomédicas da Universidade de São Paulo, nosso reconhecimento por tão nobre e valoroso local de cultura.

À Coordenadoria de Apoio a Pesquisa e Ensino Superior (CAPES), pela concessão de Bolsa de Estudos, necessária à realização do Curso de PósGraduação.

À Fundação de Amparo à Pesquisa do Estado de São Paulo (FAPESP), a Pró Reitoria Auxílio à Pesquisa (PROAP), e ao Conselho Nacional de Desenvolvimento Cientifico e Tecnologia (CNPQ), que facultaram recursos materiais ao laboratório, necessários à pesquisa.

E a todos aqueles que, direta ou indiretamente, contribuíram para a realização deste trabalho, meus sinceros agradecimentos. 
"AQUELE QUE CONHECE OS OUTROS É SÁBIO .

AQUELE QUE CONHECE A SI MESMO É ILUMINADO.

AQUELE QUE VENCE OS OUTROS É FORTE.

AQUELE QUE VENCE A SI MESMO É PODEROSO.

AQUELE QUE CONHECE A ALEGRIA É RICO.

AQUELE QUE CONSERVA SEU CAMINHO TEM VONTADE.

SEJA ILUMINADO, E PERMANECERÁS ÍNTEGRO.

CURVA-TE, E PERMANECERÁS ERETO.

ESVAZIA-TE, E PERMANECERÁS REPLETO.

GASTA-TE, E PERMANECERÁS NOVO.

O SÁBIO NÃO SE EXIBE, E POR ISSO BRILHA.

ELE NÃO SE FAZ NOTAR, E POR ISSO É NOTADO.

ELE NÃO SE ELOGIA, E POR ISSO TEM MÉRITO.

E, PORQUE NÃO ESTÁ COMPETINDO,

NINGUÉM NO MUNDO PODE COMPETIR COM ELE."

(Texto LAO-TSÉ) 


\title{
RESUMO
}

\begin{abstract}
ALLEMANDI , W. Estudo da imunorreatividade da proteína $S 100 \beta$ no Hipocampo e Núcleo do Trato Solitário de ratos neonatos submetidos à anóxia. 2011. 120 f. Tese (Doutorado em Ciências Morfofuncionais) - Instituto de Ciências Biomédicas, Universidade de São Paulo, São Paulo, 2011.
\end{abstract}

Agressões nos períodos críticos do crescimento e desenvolvimento do sistema nervoso podem modificar os eventos ontogenéticos seqüenciais com efeitos diversos e persistentes. Entre os vários fatores nocivos a essa fase está a anóxia. O organismo do neonato tem suprimento de energia anaeróbica relativamente rica, foi observado que a acidose ocorre com menor facilidade, propiciam sobrevivência e maior resistência à deficiência de oxigênio cerebral em situação normal de parto. Interessante, parece não interferir na síntese de proteínas estruturais, na multiplicação neuronal, migração celular e gliogênese. Entre as proteínas de ação relevante no SNC, sintetizadas por astrócitos está a proteína $S 100 \beta$ que exerce efeitos parácrinos e autócrinos em neurônios e glia. Sua estimulação promove sobrevivência e proteção neuronal, atuando como fator trófico e neurotrófico. A proteína $S 100 \beta$ também parece estar implicada nas fisiopatologias de doenças neurodegenerativas e doenças inflamatórias cerebrais, condições em que apresenta concentração aumentada, e por isso tem sido considerada biomarcador desses eventos. Modelo animal de anóxia neonatal desenvolvido em nosso laboratório, nos revelou ativação neural pela expressão de Fos e alterações comportamentais no grupo anóxia, o que nos instigou a explorar os efeitos da anóxia que esse estímulo estaria causando nas células da glia no Hypocampus and Nucleus of Solitary Tract, de ratos (Rattus norvegicus), machos, aproximadamente 30/44 horas de vida. Para sua exposição dos ratos à anoxia, foi utilizada câmara semi-hermética de policarbonato, a qual foi saturada com nitrogênio gasoso 100\%, fluxo 3L/minutos, pressão $101,7 \mathrm{kPa}$, durante 25 minutos. Os animais foram profundamente anestesiados, perfundidos com solução fixadora. Após remoção do cérebro foram crioprotegidos e criosseccionados em cortes frontais de 30 $\mu \mathrm{m}$ e $10 \mu \mathrm{m}$. Grupos com 2 (P2) e 7 (P7) dias após nascimento nas condições: Basal (B), sem estimulo; Sham (S) como controle experimental e Anóxia (A) com falta de oxigênio, foram analisados a imunorreatividade da proteína $S 100 \beta$ com técnicas ABC/DAB e Western blot. Identificamos o fenótipo de células da glia com a imunofluorescência de GFAP bem como sua colocalização com S100ß na formação hipocampal, foi explorada por ser uma das áreas mais sensíveis à privação de oxigênio e por seu envolvimento em aspectos cognitivos e comportamentais. Observamos significante diferença de S100ß-IR no núcleo do trato solitário, somente no grupo P2 A 2 horas em relação ao grupo P2 S 2 horas, confirmando assim nossos prévios estudos com a expressão de Fos, comprovando concomitante ativação nas células da glia diante desses estímulos. A reatividade glial de $S 100 \beta$ na formação hipocampal (CA1, CA3+CA2 e DG), apresentou diferença significante no grupo anoxia de acordo com o estágio de maturação do animal. A técnica por Western blot em toda a formação hipocampal, 2 animais por grupo, apresentou intrigante 
resultado e com aumento de $S 100 \beta$ no grupo $A$ em ambos P2 e P7, a avaliação de um todo foi diferente daquela originária de áreas especificas.

Palavras chave: Anóxia neonatal. Astrócitos. S100ß. GFAP. Western blot. Imunoistoquímica. 


\section{ABSTRACT}

ALLEMANDI, W. Study of $S 100 \beta$ protein immunoreactivity in the Hypocampus and Nucleus of Solitary Tract of newborn rats submitted to anoxia. $120 \mathrm{p}$. Thesis (Ph.D. of Morfofuncional Science) - Institute of Biomedical Sciences, University of São Paulo, São Paulo, 2011.

Attacks to the nervous system at critical growth periods can modify the sequential developmental events with several and persistent effects. Among the various harmful factors at this stage is anoxia. The high anaerobic energy supply to the newborn and a less easily acidosis occurrence provides survival and greater resistance to oxygen deficiency in brain at normal childbirth. Interestingly, it seems not to interfere in the synthesis of structural proteins, replication or in neuronal cell migration and gliogenesis. Among the proteins with important action in the CNS, is the astrocyte $S 100 \beta$ protein which exerts paracrine and autocrine effects on neurons and glia. Its stimulation promotes neuronal survival and protection, as a trophic and neurotrophic factor. S100 $\beta$ protein also seems to be implicated in the pathophysiology of neurodegenerative diseases and inflammatory brain diseases, conditions in which its concentration is enhanced therefore, it has been considered a biomarker of these events. An animal model of neonatal anoxia improved in our lab revealed neural activation by Fos expression and behavioral changes in the anoxic group, which prompted us to explore the anoxia effects on glial cells in the Hypocampus and nucleus of solitary tract, of rats (Rattus norvegicus), male, approximately 30/44 hours of life. For their exposure to anoxia, a semi-hermetic polycarbonate chamber, saturated with $100 \%$ nitrogen gas, $3 \mathrm{~L} /$ minutes flow, pressure $101.7 \mathrm{kPa}$ for 25 minutes were used. The animals were deeply anesthetized, perfused with fixative solutions. Their brains after removal were cryoprotected and cryosectioned in frontals sections of $30 \mu \mathrm{m}$ or $10 \mu \mathrm{m}$. Groups with 2 (P2) and 7 (P7) days after birth under the following conditions: Baseline (B), without stimulation; Sham (S) as the experimental control, and Anoxia (A) with lack of oxygen, were evaluated by the $S 100 \beta$ protein immunoreactivity (S100ß-IR) by $A B C / D A B$ and Western blot techniques. Also, the glial cells phenotype was identified by GFAP immunofluorescence, as well as its colocalization with $S 100 \beta$ in hippocampal formation was explored because of its sensitivity to oxygen deprivation and is involvement in cognition and behavior. The nucleus of solitary tract, significant different S100ß-IR observed, only in the P2 A 2 hours group compared to P2 S 2 hours group, confirmed previous studies with Fos-expression, besides proving that glial cells has concomitant activation by the stimulus. The glial S100ß-IR at the hippocampal formation (CA1, CA2 + CA3 and DG) presented significant difference in the anoxic group according to the maturational stage of the animal. Western blot technique of the entire hippocampal formation, two animals per group, showed intriguing result increase of $\mathrm{S} 100 \beta$ at the group $A$ at both P2 and P7, the whole evaluation was different from of that of specific areas. 
Keywords: Neonatal Anoxia. Astrocytes. S100ß. GFAP. Western blot. Immunohistochemistry. 


\section{LISTA DE ILUSTRAÇÕES}

Figura 1- Esquema sensores de oxigênio e receptores especializados 28

Figura 2- Esquema da parede do tubo neural, organização e migração celular 30

Figura 3- Sistema utilizado para provocar anoxia nos ratos neonatos $\quad 47$

Figura 4- Identificação do Núcleo Trato Solitário no encéfalo 53

Figura 5- Fotomicrografia de S100ß-IR no Núcleo Trato Solitário 54

Figura 6- Quantificação de células S100ß-IR na Formação Hipocampal 55

Figura 7- S100ß-IR e camadas das regiões da Formação Hipocampal 56

Figura 8- $\quad$ Esquema do Retículo $\quad 57$

Figura 9- Fotomicrografia em Nissl com esquema das camadas quantificadas em regiões da Formação hipocampal $\quad 57$

Figura 10- Saturação Periférica de Oxigênio $\quad 60$

Figura 11- Gráfico da média e desvio padrão de células S100ß-IR no NTS, do grupo P2 $2 \mathrm{~h}$ e P2 $7 \mathrm{~h}$

Figura 12- S100ß-IR no Nucleo Trato Solitário, grupo P2 2 h , 7 h

Figura 13- Imunofluorescência de $S 100 \beta$ vs GFAP em P2, no grupo P2, região CA3 da Formação Hipocampal

Figura 14- Imunofluorescência de $S 100 \beta$ vs GFAP em P7, no grupo P7, região CA3 da Formação Hipocampal

Figura 15- Gráfico da média e desvio padrão de células S100ß-IR em CA1, na Formação Hipocampal em ratos P2 e P7

Figura 16- Fotomicrografias em campo claro de S100ß-IR, ilustram a organização das camadas na região CA1 da Formação Hipocampal

Figura 17- Fotomicrografias em campo claro de cortes imunorreativos para detecção de S100ß em CA1, na Formação Hipocampal, grupo P2

Figura 18- Fotomicrografias em campo claro de cortes imunorreativos para detecção de S100ß em CA1, na Formação Hipocampal, grupo P7

Figura 19- Gráfico da média e desvio padrão de células S100ß-IR em CA3+ CA2 na Formação Hipocampal em ratos P2 e P7

Figura 20- Fotomicrografias em campo claro de S100ß-IR, ilustram a organização das camadas na região CA3+CA2 da Formação Hipocampal

Figura 21- Fotomicrografias em campo claro de cortes imunorreativos para detecção de S100ß em CA3+CA2, Formação Hipocampal, grupo P2

Figura 22- Fotomicrografias em campo claro de cortes imunorreativos para detecção de S100ß em CA3+CA2, Formação Hipocampal, grupo P7

Figura 23- Gráfico da média e desvio padrão de células S100ß-IR em DG, na Formação Hipocampal em ratos P2 e P7

Figura 24- Fotomicrografias em campo claro de S100ß-IR, ilustram a organização das camadas na região DG da Formação Hipocampal

Figura 25- Fotomicrografias em campo claro de cortes imunorreativos para detecção de S100ß em DG, Formação Hipocampal, grupo P2 
Figura 26- Fotomicrografias em campo claro de cortes imunorreativos para detecção de S100ß em DG, Formação Hipocampal, grupo P7

Figura 27- Efeito das variações na quantificaçãode S100ß-IR por Western blot, na Formação Hipocampal do grupo P2

Figura 28- Efeito das variações na quantificação de S100ß-IR por Western blot, na Formação Hipocampal em ratos do grupo P7

Figura 29- Gráfico da média e desvio padrão da DO (\%) obtida na quantificação de S100ß-IR por Western blot na Formação Hipocampal em ratos P2 e P7 


\section{LISTA DE TABELAS}

Tabela 1- Delineamento experimental, grupos avaliados em imunoistoquímica 43

Tabela 2- Delineamento experimental, grupos avaliados em Western blot

Tabela 3- Média e desvio padrão do número de células S100ß-IR no NTS

Tabela 4- Média e desvio padrão do número de células S100ß-IR em CA1 na Formação Hipocampal, em ratos do grupo P2 e P7, nas condições: Basal (B) Sham (S) e Anóxia (A)

Tabela 5- Média e desvio padrão do número de células S100ß-IR em CA3+CA2 Formação Hipocampal, em ratos do grupo P2 e P7, nas condições: Basal (B) Sham (S) e Anóxia (A)

Tabela 6- Média e desvio padrão do número de células S100ß-IR em DG na Formação Hipocampal, em ratos do grupo P2 e P7, nas condições: Basal (B) Sham (S) e Anóxia (A)

Tabela 7- Média e desvio padrão da densidade óptica (\%) obtida na quantificação de células S100ß-IR por Western Blot, em ratos do grupo P2 e P7 nas condições: Basal (B), Sham (S) e Anóxia (A) 


\section{LISTA DE ABREVIATURAS}

A - Condição experimental Anóxia

ABC - Complexo Avidina-Biotina

ABS - Absorbância por Espectrofotometria

AD - Doença de Alzheimer

ATP - adenosina trifosfato

B $\quad$ - Condição experimental Basal

BBB - barreira hemato-encefálica

$\mathrm{Ca}^{2}+\quad$ - 2 sítios de ligação de cálcio

CA1 - Corno de Ammonn 1

CA2 - Corno de Ammonn 2

CA3 - Corno de Ammonn 3

CA4 - Corno de Ammonn 4

DAB - 3-3'- Diaminobenzidina tetrahidrocloreto

GFAP - Proteína Glial Fibrilar Ácida

HI - Hipóxico-Isquêmica

$\mathrm{NaCl} \quad$ - solução salina

NFkB - Fator de Transcrição Nuclear

NGS - Soro Normal de Cabra

NMDAR - N-Methyl-d-Aspartate Receptors

NO - Óxido Nitrico

NOs - enzima de Óxido Nítrico

NTS - Núcleo do Trato Solitário

P2 - Grupo rato com 2 dias de vida

P7 - Grupo rato com 7 dias de vida

PBS - Tampão Fosfato de Sódio

RNA - ácidoribonucleico

S $\quad$ - Condição experimental Sham

SD - Síndrome de Down

S100 $\beta$ - forma beta de S100

SNC - Sistema Nervoso Central 
1 INTRODUÇÃO

1.1 Anóxia neonatal 25

1.2 Sistema Nervoso Central e Privação de Oxigênio 27

1.3 Ontogênese dos Elementos Celulares do SNC 29

1.4 S100 e S100beta (S100ß) 33

1.4.1 Mecanismos de Ação de S100ß no Meio Intratracelular 34

1.4.2 Mecanismos de Ação de S100ß no Meio Extratracelular 35

1.5 Formação Hipocampal 37

2 OBJETIVOS 39

3 MATERIAL E MÉTODOS 42

3.1 Animais 43

3.2 Delineamento Experimental 43

3.2.1 Condição Basal (B) 44

3.2.2 Condição 'Sham" (S) 44

3.2.3 Condição Anóxia $(A) \quad 45$

3.3 Condições Experimentais 46

3.4 Processamento do Material Biológico para Imunoistoquímica Perfusão e Microtomia (Criostato) 48

3.4.1 Titulação de anticorpos primários: S100ß e GFAP 49

3.5 Método de Imunoistoquímica: S100ß-IR 50

3.6 Método Imunofluorescência em lâmina: Dupla marcação S100ß, GFAP 51

3.7 Método de Western blot na Formação Hipocampal 51

3.8 Método para Análise Quantitativa no Núcleo do Trato Solitário 53

3.9 Método para Análise Quantitativa na Formação Hipocampal 54

3.10 Análise e Produções de Imagem 59

3.11 Análise Estatística $\quad 59$

4 RESULTADOS 60

4.1 Considerações Experimentais $\quad 61$

4.2 Desenvolvimento Validação do Modelo Experimental utilizado: Anóxia 61

4.3 Estudos dos Efeitos da Anóxia em Astrócitos pela S100ß-IR 62

4.5 Resultados de S100ß-IR no NTS: 2 h e 7 h pós experimentos 64

4.7 Resultados de S100ß-IR, na Formação Hipocampal 71

4.7.1 Análise Quantitativa para S100ß-IR na Formação Hipocampal em CA1 grupo P2 e P7, condições: $B$, S e $A$

4.7.2 Análise Quantitativa para S100ß-IR na Formação Hipocampal em CA3 $+C A 2$, grupos $P 2$ e P7, condições: $B, S$ e $A$

4.7.3 Análise Quantitativa para $S 100 \beta-I R$ na Formação Hipocampal em DG grupos $P 2$ e P7, condições: $B, S$ e $A$

4.8 Análise Quantitativa de S100ß-IR, da Formação Hipocampal por Western blot

4.8.1 Análise por Western blot para $S 100 \beta-I R$ na Formação Hipocampal, grupo P2, condições: $B, S$ e $A$

4.8.2 Análise por Western blot para S100ß-IR na Formação Hipocampal, grupo P7, condições: $B, S$ e $A$ 
4.8.3 Análise por Western blot para S100ß-IR na Formação Hipocampal, grupos $P 2$ vs $P 7$, condições: $B, S$ e $A$

5 DISCUSSÃO

5.1 S100ß-IR, na Formação Hipocampal 89

5.2 S100ß-IR e sua relação Neurônio vs Glia na Formação Hipocampal 94

6 CONCLUSÃO $\quad 97$

REFERÊNCIAS 99

ANEXOS 120

Anexo 1 Animal Model of neonatal anoxia: Development and Efficiency 121

Anexo $2 S 100 \beta$ protein expression: gender- and age-related daily changes. $\quad 130$

Anexo 3 A comparative study of cytoarchitecture and serotonergic afferents $\quad 139$

Anexo 4 Métodos em Neurociência 
1 INTRODUÇÃo 


\subsection{Anóxia Neonatal}

Na ontogênese do sistema nervoso de mamíferos, tem sido evidenciado por demonstrações experimentais e clínicas que, agressões nestes períodos críticos podem modificar os eventos ontogenéticos seqüenciais com efeitos diversos e persistentes (MORGANE et al., 1993). Estas mudanças poderão ser reversíveis ou não, dependendo da magnitude da agressão e dos fatores ambientais a que são submetidos os indivíduos (observados desde 1972, por LEVITSKY e BARNES).

Entre os vários fatores que podem alterar os eventos do crescimento e desenvolvimento do sistema nervoso, está a anóxia. Esta representa o grau extremo de hipóxia (diminuição de oferta de oxigênio), verificado quando o suprimento de oxigênio para as células é praticamente zero.

O metabolismo encefálico normal requer oxigênio e glicose. O encéfalo representa $2 \%$ da massa corporal total e é o responsável pelo consumo de $20 \%$ do oxigênio total e $25 \%$ da demanda total de glicose, razões por que uma falência cárdio pulmonar de 10 a 15 segundos pode ocasionar lesão encefálica, irreversível (OLIVEIRA-ALONSON e SILVEIRA, 2007).

A utilização de glucose cerebral e o seu transporte transmembrana, estão diminuídos em ratos com sete dias de vida pós natal $(P 7)$ em relação a ratos adultos (VANNUCCI, 1989). O neonato apresenta suprimento de energia por processos anaeróbicos relativamente ricos, devido à maior disponibilidade de glicogênio cerebral (NEHLIG e PEREIRA DE VASCONCELOS, 1993). A glicólise anaeróbica é, entretanto consideravelmente operativa até P10, e decai seqüencialmente a P14 ou P21 (BOMONT et al., 1992) mas é considerada suficiente para a homeostase iônica nessa fase (BALLANYI et al., 1993).

Embora essa glicólise anaeróbica favoreça o acumulo de lactato no cérebro imaturo (DAHLQUIST e PERSSON, 1976), não constitui problema, pois a barreira hemato encefálica (BBB) ainda incompleta em neonatos minimiza a ocorrência de acidose. Esta condição poderia explicar a alta resistência dos neonatos em Hipóxia-Isquemia (HI) aguda, conforme pesquisas que indicam responsividade diferenciada de neonatos em relação a ratos adultos em ataque hipóxico-isquêmico (NYAKAS et al., 1996; HADDAD e DONELLY 1990). Adicionalmente, é sabido que neurônios imaturos necessitam 
menos energia (NYAKAS et al., 1996; BICKLER et al., 1996; NEHLIG e PEREIRA DE VASCONCELOS, 1993), bem como, a comunicação intercelular a nível sináptico é moderada, nos períodos pré e pósnatal nos ratos, sendo baixa a síntese de neurotransmissores (KRJANC et al., 1994; CHERICl et al., 1991).

No SNC, em decorrência de seu maior metabolismo, a privação de oxigênio pode causar lesão ou morte celular em áreas cerebrais mais sensíveis, tais como formação hipocampal, córtex cerebral, núcleos da base (CIRULLI et al., 2003).

Experimentos crônicos de hipóxia podem interferir na síntese de proteínas estruturais e outras macromoléculas, situação verdadeira também nos eventos da ontogênese quanto à multiplicação neuronal, gliogênese e migração celular, tendo sido observado que rápida diferenciação e sinaptogênese podem decorrer de agressões hipóxico-isquêmica ou asfixia (SLOTKIN et al., 1986). Embora os efeitos dessa depleção de oxigênio possam ser diversos, pois dependem do estágio de maturação do organismo, da duração do estimulo, assim como da sensibilidade celular e da região acometida incluindo ainda fatores como má nutrição, hipoglicemia, temperatura corpórea, pressão sanguínea e complicações clínicas (CIRULLI et al., 2003).

Em condição pré-natal a interrupção no fluxo de sangue placentário e nas trocas gasosas, culmina em necrose ou apoptose, em decorrência de complexa cascata de eventos como acidose, formação de radicais livres, acúmulo de cálcio, peroxidação lipídica e neurotoxicidade pelo glutamato e óxido nítrico. Tais eventos rompem as estruturas celulares ocasionando morte celular, com a reperfusão sanguínea estes eventos regridem (CIRULLI et al., 2003).

Tem sido observado em humanos, que durante o parto, neonatos apresentam redução na pressão parcial de oxigênio $\left(\mathrm{pO}^{2}\right)$ e $\mathrm{pH}$, característicos de leve asfixia fisiológica natural, que entretanto não causa danos ao encéfalo em desenvolvimento. Embora quando fatores relacionados à anóxia, hipóxia, isquemia, que aumentam a privação de oxigênio ao neonato, há probabilidade de ocorrer doenças neurológicas de desenvolvimento, que se caracteriza por espasticidade e anormalidade motora associada a déficits cognitivos (STRATA, 
2004; VOLPE 1992) o que tem sido mencionado como uma das causas da paralisia cerebral (PC) de etiologia peri e neonatal.

O acompanhamento clínico de pacientes carece de indicador da intensidade do dano encefálico de forma a traçar e estabelecer prognóstico. A literatura tem relatado teores aumentados da proteína S100 $\beta$ nessas condições, tanto nos valores séricos como no liquido cérebro-espinal, o que the tem rendido a denominação de proteína biomarcadora de danos ou disfunções cerebrais (MRAK e GRIFFIN, 2001).

\subsection{Sistema Nervoso Central e Privação de Oxigênio}

$\mathrm{Na}$ privação de oxigênio é disparada complexa cascata de eventos bioquímicos que ocorrem quase que simultaneamente promovendo interrupção do metabolismo energético, desequilíbrio ácido-básico, acúmulo de espécies oxigênio-reativo e de aminoácidos excitatórios no espaço extracelular, perda do equilíbrio de água celular e inicio da apoptose (VEXLER e FERREIRO, 2001). É importante ressaltar que estes eventos são rápidos e de curta duração assim, o espaço de tempo para intervenções terapêuticas é bastante reduzido.

A depleção de ATP, resultante da hipóxia/anóxia tem importantes conseqüências, incluindo falha no funcionamento das bombas iônicas de sódiopotássio, ativação da formação de radicais livres (LOIDL et al., 2000; DELL'ANNA et al., 1997), mudanças no estado de fosforilação de diferentes enzimas e proteínas estruturais (LOFTON, 1989). A falha nas bombas iônicas permite a passagem de íons pela membrana abaixo dos gradientes de concentração. A conseqüente despolarização anóxica leva a uma cadeia de conseqüências letais, entre as quais, há perda massiva de neurotransmissores como glutamato, aspartato e dopamina para o espaço extracelular em quantidade tóxica (LOFTON, 1989). Ainda o aumento descontrolado de cálcio intracelular é particularmente nocivo, por ocasionar efeitos múltiplos disfuncionais como ativação de hidrólise fosfolipídica com aumento da formação de radicais livres.

O organismo reage nessas situações com processos homeostáticos para manter as condições de equilíbrio dinâmico. O incremento no aporte de oxigênio pode ser realizado pela regulação da ventilação, processo rítmico 
inconsciente gerado automaticamente por grupos de células nervosas localizadas no tronco encefálico, chamados gerador central de padrão (SILVERTHORN, 2003). De forma que o grau de distensão dos alvéolos pulmonares é continuamente informado aos núcleos do trato solitário (NTS) por fibras aferentes viscerais gerais do nervo vago, que então excitam os centros respiratórios. Atuam também, sensores de oxigênio presentes nas paredes da aorta e da artéria carótida comum, corpo aórtico e corpo carotídeo, estes alojam quimiorreceptores e mecanorreceptores sensíveis ao estiramento das paredes arteriais, são as células glomus que recebem inervação aferente de fibras dos nervos glossofaríngeo e nervo vago, respectivamente, com quem estabelecem sinapse química (LEVITZKY, 2004; FINLEY e KATZ, 1992) (Figura 1- A/B).

Figura 1- Esquema sensores de oxigênio e receptores especializados
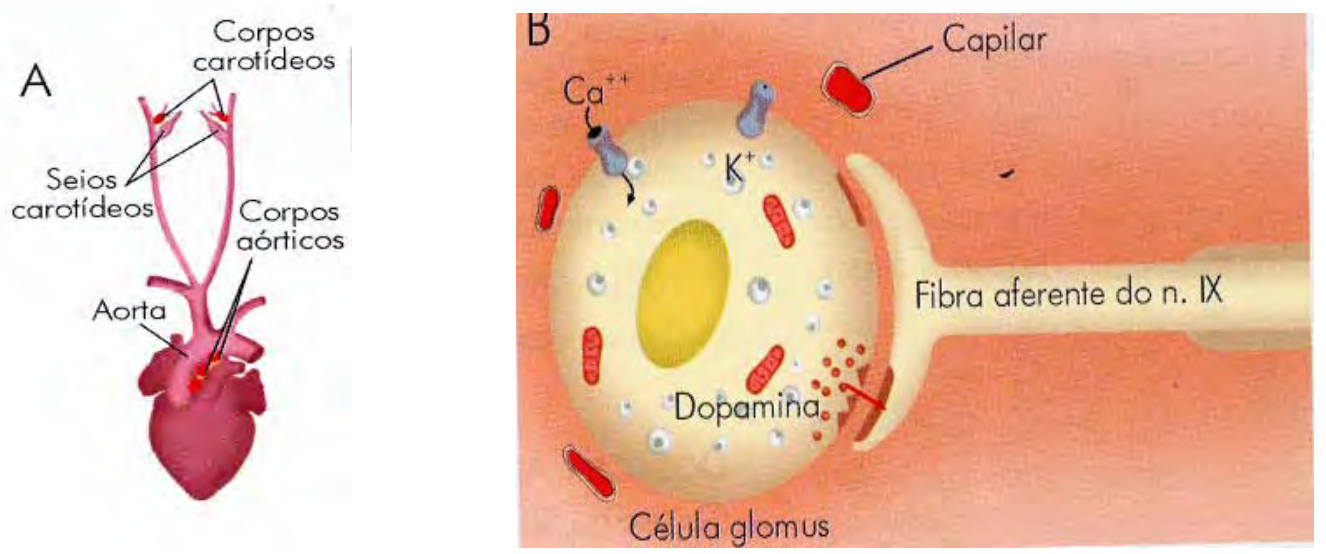

(A), ilustra a localização do corpo aórtico e corpo carotídeo localizado respectivamente nas paredes da aorta e da artéria carótida comum. (B), ilustra o funcionamento das células glomus que compõem os quimiorreceptores e mecanorreceptores da figura $A$.

Fonte: Modificado de 100 Bilhões de Neurônios de Roberto Lent, (2001).

Após promover uma hipóxia citotóxica, a despolarização das terminações neurais aferentes localizadas no corpúsculo carotídeo induz potenciais de ação geradores que se propagaram para outra terminação localizada no NTS, que está envolvido no controle da função cardiovascular. O NTS inicia ajustes respiratórios e cardiovasculares necessários para a normalização da pressão arterial e a redução da freqüência cardíaca, bem como provoca alterações comportamentais de exploração do ambiente, típicas de situação de hipóxia (LEVITZKY, 2004; FINLEY e KATZ, 1992; VIZEK et al., 1987). 
Recente artigo, "Astrocytes Control Breathing Through pH-Dependent Release of ATP", (GOURINE et al., 2010), relata papel do astrócito como elemento fundamental nos circuitos cerebrais que controlam funções vitais como a respiração. Essa pesquisa identifica e indica que os astrócitos cerebrais, são capazes de perceber alterações nos níveis de dióxido de carbono e de acidez no sangue e no cérebro, podendo, portanto, via ATP, ativar redes cerebrais envolvidas na respiração, de modo a aumentar a respiração de acordo com a atividade e o metabolismo do organismo colaborando com a homeostase (GOURINE et al., 2010).

\subsection{Ontogênese dos Elementos Celulares do Sistema Nervoso Central}

No SNC existem três categorias celulares distintas: neurônio; glia: astrócito, oligodendrócito e microglia; e células ependimárias. Deve-se a Ramón Y Cajal, (1972) já no século XIX, a classificação dos tipos celulares da glia, no papel de verdadeiros elementos polivalentes no sistema nervoso. Algumas células neurais são altamente plásticas: proliferam e adquirem identidade regional são as células tronco neurais, progenitoras primárias que dão origem a neurônios e glia no cérebro de ratos embriônicos, neonatal e adulto. (MERKLE e BUYLLA, 2006; ANTHONY, et al., 2004; DOESTSCH, 2003; GOLDMAN, 2003).

A maior vulnerabilidade à agressão do neonato a anóxia tem sido relacionada a alterações nos processos de mitose celular, tanto dos neurônios quanto da glia desse período, embora estas células se multipliquem em diferentes períodos e a gliogênese preceda inicialmente a neurogênese (MORGANE et al., 1993). Essa consideração evidencia a importância crucial de adequado suprimento cerebral, especialmente quando axônios e dendritos estão intensamente estabelecendo suas interconexões sinápticas sejam elas locais ou em alvos de projeção.

Histologistas observaram que o tubo neural apresenta paliçada de células da glia cujos prolongamentos estendem-se da superfície ventricular à superfície pial: essas células são conhecidas pelo seu coletivo como glia radial (PASKO RAKIC, 1972) (Figura 2). Quando essas células alcançam o sitio alvo, 
é iniciado o processo de diferenciação nos aspectos morfológicos, bioquímicos e funcionais.

Figura 2- Esquema da parede do tubo neural, organização e migração celular

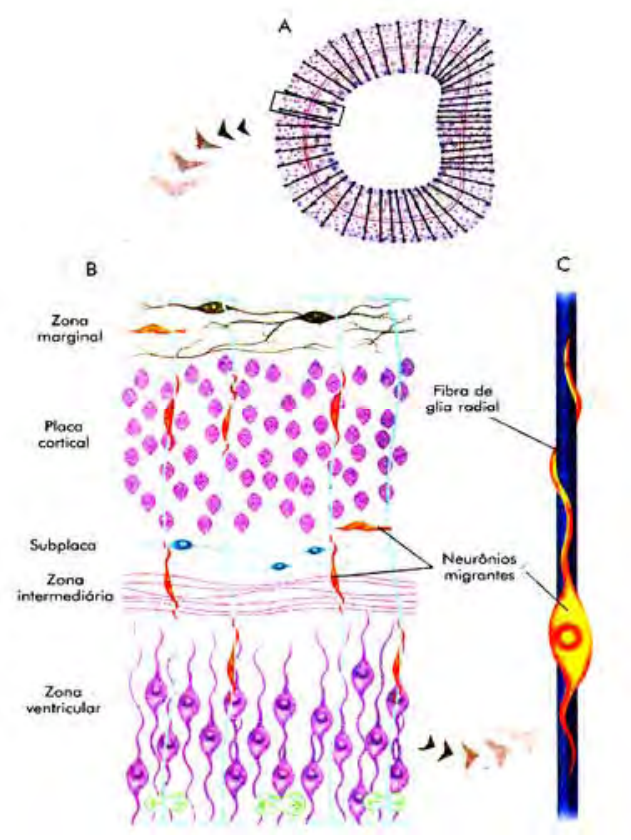

(A), paliçada de prolongamentos radiais.

(B), esquema da organização celular de células precoces chamadas, glia radial (em azul claro). (C), Prolongamentos radiais (em azul escuro) atuam como "trilhos" sobre os quais migram alguns dos neurônios pós-mitóticos juvenis (em amarelo).

Fonte: Modificado de "100 Bilhões de Neurônios" de Roberto Lent, (2001).

Astrócitos constituem as maiores e mais numerosas células da glia presentes no SNC dos mamíferos. A proteína glial fibrilar ácida (GFAP) é componente dos filamentos intermediários presentes em astrócitos (BONDAN et al., 2003; BIGNAMI e DAHL, 1994). Esta célula sofre acentuada alteração nos filamentos que a compõe durante o desenvolvimento (FEDOROFF 1986). Com o amadurecimento da célula, a proteína glial fibrilar ácida (GFAP) se torna presente (DAHL, 1981) em muitos astrócitos da substância cinzenta (LOFTON, 1989). Durante a segunda e a terceira semana de vida extra-uterina tende a ocorrer a expressão de GFAP como principal componente dos filamentos intermediários (BONDAN et al., 2003; TAKAMIYA et al., 1988; SCHIFFER et al., 1986; PIXLEY e VELLIS, 1984).

Os astrócitos possuem prolongamentos muito numerosos que emergem do soma e se ramificam profusamente, formando densa arborização. Na sua 
organização estrutural estão estrategicamente posicionados em relação aos neurônios, aos capilares, às meninges e à camada de células que reveste as cavidades internas do SNC, evidenciando algumas das suas diversas atuações funcionais, recobrem os vasos sanguíneos, participam da barreira hematoencefálica; envolvem as sinapses com pedículos que participam da reposição dos íons e moléculas envolvidas na transmissão sináptica; ancoram-se na camada ependimária do ventrículo e na pia-máter participando da troca de moléculas entre o líquido cérebro-espinal e o tecido nervoso; apresentam capacidade proliferativa formando cicatriz glial ao redor de lesões (gliose); contribuem para a sobrevida dos neurônios produzindo e liberando fatores tróficos na região da lesão os quais propiciam também, que antígenos exteriorizados na membrana ativem células do sistema imunitário, linfócitos $T$, (RICHTER, 1998).

À identificação dos fatores neurotróficos seguiu-se à descoberta de que o fenômeno da morte celular natural, apoptose, fenômeno que ocorre em todo o sistema nervoso das diferentes espécies animais, como mecanismo de ajuste numérico das populações de neurônios em relação aos seus alvos. Os fatores tróficos são produzidos pelos alvos e então, secretados e capturados pelos neurônios que com eles fazem contato sináptico. No interior dos neurônios, atuam sobre o DNA bloqueando o processo ativo de "suicídio" da célula. Assim as células que conseguem estabilizar suas sinapses obtêm suficiente quantidade de fatores neurotróficos do alvo e sobrevivem, mas as que não conseguem entram em apoptose e desaparecem. Nestes ajustes, a intensidade do estimulo nocivo e o período de resposta são críticos (ROBBINS, 2000).

O estado de sobrevida ou de morte neuronal é dependente de vários mecanismos de sinalização ainda pouco conhecidos. Sabe-se, no entanto, que o astrócito está envolvido nesse processo (STRÖMBERG et al., 1986). É do conhecimento que células da glia reativas estão envolvidas em respostas funcionais intrínsecas, incluindo a síntese e a liberação de substâncias neuroativas (GIULIAN et al., 1996; MARTIN, 1992), por tal, postula-se que astrócitos (e microglia) ativados exerçam influência nos eventos tróficos nesses locais mais sensíveis à agressão, assim como nas vias neuronais lesadas (LEME e CHADI, 2001; GIULIAN et al., 1996). 
Estudos recentes indicam as células da glia como terceiro elemento em sinapse química (OLIET e MOTHET, 2009). A ativação sináptica de células da glia atua como gatilho intracelular nas vias de segundo mensageiro incluindo aumento de $\mathrm{CA}^{2}+$ (PEREA e ARAQUE, 2005; ARAQUE, 2002), ação esta que varia de acordo com impulsos sináptico e receptores de glia envolvidos (DEITMER et al., 1998; PASTI et al., 1997). A ativação dessa via de segundo mensageiro induz a liberação de substancias ativas, gliotransmissores, por analogia aos neurotransmissores (VOLTERRA e MELDOLESI, 2005), entre eles estão glutamato (LEE et al., 2007; TAKANO et al., 2005), ATP (JOURDAIN et al., 2007; GORDON et al., 2005; NEWMAN, 2003) e taurina (DELEUZE et al., 1998).

A D-serina, também tem sido indicada e até com função predominante (MARTINEAU et al., 2006; MILLER, 2004), como o maior ligante endógeno, sugerindo que D-Serina poderia ser uma alternativa da glicina, na ativação de N-Methyl-d-Aspartate Receptors (NMDAR) (HASHIMOTO et al.,1995a, b); atua na transmissão sináptica e plasticidade sináptica, ritmogênese e excitotoxicidade; possuem uma propriedade peculiar, pois sua ativação requer ligante de glutamato e coagonista semelhante glicina ou D-serina (OLIET e MOTHET, 2009).

Portanto, hoje está claro que células da glia contribuem ativamente no desenvolvimento de sinapse (OLIET e MOTHET, 2009; CHRISTOPHERSON et al., 2005; SLEZAK e PFREIGER, 2003), na transmissão sináptica (JOURDAIN et al., 2007; SERRANO et al., 2006; PANATIER et al., 2006; PASCUAL et al., 2005; GORDON et al., 2005) e excitabilidade neuronal (TIAN et al., 2005; ANGULO et al., 2004; FELLIN et al., 2004). A descoberta contínua de substâncias com propriedades neurotróficas e suas ações em lesões neuronais estimula a pesquisa dos fenômenos envolvidos na regulação celular trófica mediada pelas células da glia (GIULIAN e VACA, 1993; CHADI et al., 1993). 


\subsection{S100 e S100beta (S100ß)}

A proteína S100 faz parte de família multigênica de ligantes de cálcio e tem sido implicada em atividade regulatória intra e extracelular. Essa proteína apresenta baixo peso molecular, entre 9 e $13 \mathrm{kDa}$ é caracterizada pela presença de 2 sítios de ligação de cálcio $\left(\mathrm{Ca}^{2}+\right)$. Membros da família dessa proteína apresentam interações com várias proteínas intracelulares efetoras, as quais atuam na regulação das atividades enzimáticas, na dinâmica dos constituintes do citoesqueleto, no crescimento e diferenciação celular e na homeostasia do $\mathrm{Ca}^{2}+$ (DONATO, 2003). Sua ação tem sido relatada como reguladora da atividade do tecido nervoso no sistema nervoso central: neurônios, astrócitos, microglia e células epiteliais e endoteliais e em receptor celular superficial (DONATO, 2001; SCHAFER e HEIZMANN, 1996; ZIMMER et al., 1995).

Frações da proteína $S 100 \beta$ do encéfalo de boi evidenciaram que S100 na verdade é composto de dois polipeptídeos S100A1 e S100ß (MOORE, 1965). A proteína $S 100 \beta$, além de ser membro da superfamília $S 100-$ calmodulina-troponina ligante de $\mathrm{Ca}^{2+}$, é também ligante de $\mathrm{Zn}^{2+}$. Sua distribuição no SNC é ampla (HEIZMANN, 1999). Ela influencia respostas celulares modulando íons $\mathrm{Ca}^{2}+$ por sinal de transdução, em diferentes pontos na cascata desses eventos, regulando diretamente a resposta celular, como exemplo na transcrição nuclear (SCHAFER e HEIZMANN, 1996; O'CALLAGHAN, 1991).

A proteína $S 100 \beta$ codificada nas células da glia (astrócitos) se expressa intensamente durante o desenvolvimento do SNC (WAINWRIGHT et al., 2004). A forma beta $(\mathrm{S} 100 \beta)$, apresenta baixo peso molecular, $21 \mathrm{kDa}$, parece ser a única que apresenta efeitos sobre o desenvolvimento e plasticidade do sistema nervoso, (WHITAKER-AZMITIA e AZMITIA, 1989).

$\mathrm{S} 100 \beta$ tem sido reportada como fator trófico e neurotrófico, por atuar principalmente na extensão dos neuritos, e assim influenciar a integridade do citoesqueleto, (ROTHERMUNDT et al., 2003; DONATO, 2003; 1988; 1985; SORCl et al., 1998). Sua estimulação promove sobrevivência e proteção neuronal, na formação cicatricial (CUNHA et al., 2007; ROTHERMUNDT et al., 2003; UEDA et al., 1995; BHATTACHARYYA et al., 1992; VAN ELDIK et al. 
1991; SELINFREUND et al., 1991; WHITAKER-AZMITIA et al., 1990). Tem sido observada interação entre $\mathrm{S} 100 \beta$ e o sistema imune cerebral (ROTHERMUNDT et al., 2003), onde parece exercer efeito protetor ao manterse em nível fisiológico dentro das células (DONATO, 2001).

\subsubsection{Mecanismos de Ação de $S 100 \beta$ no Meio Intratracelular}

A maior concentração de $\mathrm{S} 100 \beta, 80$ a 90\% do total da proteína é encontrada no cérebro, o restante está localizado em outros tecidos sendo localizada no interior do citoplasma, apenas 5 a 7\% da proteína é encontrada na membrana (GHANDOUR et al., 1981). Independentemente do local em que esteja, ela atua inibindo a fosforilação de outras proteínas, por interagir com substratos quinases, (PK) e pela proteína fosfatase (PP) (ALBERTS et al., 1994), bloqueando o acesso dessas proteínas quinases a esses substratos. $A$ função dessa inibição é desconhecida, mas alguns resultados sugerem que S100ß participa principalmente na diminuição do sinal de transdução, particularmente por estar ligada a elevação da concentração de cálcio no citosol, o que determina fosforilação de proteínas alvo e assim regula etapas em alguns meios de sinalização (DONATO, 2001).

$\mathrm{S} 100 \beta$ alem de modificar a resposta na fase inicial da cascata de transdução do sinal via PK e PP (BAUDIER e COLE, 1988) pode regular o metabolismo energético pela modulação da atividade de várias enzimas incluindo a adenilil ciclase, gliceraldeido-3-fosfato desidrogenase e frutose-1,6bifosfato aldolase (DONATO, 1999), e inibir a polimerização da GFAP em resposta ao aumento do $\mathrm{Ca}^{2}+(B I A N C H I$ et al., 1994), e assim influenciar no citoesqueleto, ou seja, no estado de polimerização de microtúbulos e filamentos de actina, filamentos intermediários. (DONATO, 1999; HEIZMANN, 1999). Interações de S100, com anexinas específicas ligadas a fosfolipicos têm sido demonstradas somente in vitro, a especificidade e seu papel ainda é objeto de estudo (HARDER e GERKE, 1993).

Apesar dos vários estudos sobre $S 100 \beta$ e das funções identificadas, ainda não são conhecidos os mecanismos que regulam a expressão de S100ß em astrócitos reativos, pós lesão no SNC (CUNHA et al., 2007; ROTHERMUNDT et al., 2003; REEVES et al., 1994). 


\subsubsection{Mecanismos de Ação de S100ß no Meio Extracelular}

Alguns trabalhos mostram que estímulos sob o comando de estresse metabólico (como hipoglicemia), estão associados à secreção de $S 100 \beta$ (GERLACH et al., 2006). Existe a hipótese de um domínio hidrofóbico, permitindo interação com a membrana ou com proteínas de membrana, como as anexinas (SCHAFER e HEIZMANN, 1996). Outro mecanismo está associado com ação de estruturas presentes na superfície dos astrócitos, receptores extracelulares serotonérgicos, que após ligação com moléculas específicas, induz ao desacoplamento e à ativação de proteínas $\mathrm{G}$ existentes no interior da membrana plasmática destas células, ocasionando propagação de diversos sinais intracelulares, (DIB et al., 1994; GLOWINSKI et al., 1994). Tem sido sugerido que a ativação destas vias de segundos mensageiros em receptores neurais serotonérgicos e glutamatérgicos metabotrópicos, iniciada por mecanismo da glia, induz a aumento concomitante da expressão dos receptores 5HT1A. Por sua vez, o aumento da expressão dos receptores 5HT1A, promove secreção e liberação de S100ß (WHITAKER et al., 2001, 1993; HARING et al., 1993).

A presença de transportadores para glutamato na membrana de astrócitos corrobora esses achados (STANIMIROVIC et al., 1999; GEGELASHVILI e SCHOUSBOE, 1997), de que ele modula a secreção de $\mathrm{S} 100 \beta$ pelos astrócitos. Entretanto, foi observado que níveis tóxicos de glutamato liberados pelos neurônios reduzem a secreção de S100 $\beta$ pelos astrócitos da formação hipocampal de ratos (TRAMONTINA et al., 2006). Além do glutamato, a expressão de $\mathrm{S} 100 \beta$ por astrócitos tem sido associada à estimulação de interleucina-1 (IL-1) e por AMP-cíclico (ZIMMER et al., 1995).

Os efeitos da proteína $S 100 \beta$ e seus mecanismos de ação no meio extracelular são concentrações dependentes podendo exercer efeitos tróficos ou tóxicos. Em concentração nanomolar (nM), extracelular, in vitro, ela estimula crescimento de neuritos no córtex do cérebro (ROTHERMUNDT et al., 2003; VAN ELDIK et al., 1991; WINNINGHAM-MAJOR et al., 1989). Essa condição classificou a proteína como neurotrófica, aumentando a sobrevida neuronal, estimulando e interagindo com fatores de transcrição (SCHAFER e HEIZMANN, 1996; O'CALLAGHAN, 1991; WHITAKER et al., 1990). Nessa 
concentração ela estimula o fluxo de $\mathrm{Ca}^{2+}$, e atua como segundo mensageiro. Essa hipótese foi evidenciada, em experimentos mostrando que o $\mathrm{Ca}^{2}+$, é necessário e suficiente para regular extensão neurítica (GU et al., 1995). Assim como, também aumenta a sobrevivência dos neurônios em vários sistemas durante o desenvolvimento (ROTHERMUNDT et al., 2003; UEDA et al., 1995; BHATTACHARYYA et al., 1992; VAN ELDIK et al., 1991; WHITAKER-AZMITIA et al., 1990). Esta ação neuroprotetora foi observada após danos decorrentes da privação de glucose nos neurônios da formação hipocampal de ratos (ROTHERMUNDT et al., 2003).

Em contraste, efeitos tóxicos da proteína $\mathrm{S} 100 \beta$, no meio extracelular, em concentração micromolar de $\mathrm{S} 100 \beta$, in vitro, foram observados com o estimulo da expressão de citosinas pró-inflamatórias e indução de apoptose (ROTHERMUNDT et al., 2003). O aumento dessa proteína induz resposta inflamatória mediada por NFkB (Fator de Transcrição Nuclear) em astrócitos, dessa forma iNOS (enzima de síntese de óxido nítrico) passa a produzir o NO (óxido nítrico), que consequentemente provoca morte celular com características definidas por apoptose (HU et al., 1997, 1996). Esses efeitos produzem danos neurodegenerativos pela indução do RNA-mensageiro (ácidoribonucleico) e expressão da proteína precursora da $\beta$-amilóide (LI et al., 1998). Da mesma forma ocorre com os níveis de cálcio intracelular, não somente alterando a função de proteínas ligantes de cálcio como também a expressão, como documentado em doenças humanas neurodegenerativas (FANO et al., 1995).

É conhecido que, S100ß cuja expressão está seletivamente aumentada em astrócitos de idosos, na Doença de Alzheimer (AD) e na Síndrome de Down (SD), têm sido implicada nas fisiopatologias de doenças neurodegenerativas assim como em doenças inflamatórias cerebrais (DONATO, 2003; GRIFFIN et al., 1998; 1989). Níveis elevados de $S 100 \beta$ foram encontrados em pacientes portadores de esclerose múltipla (VAN ELDIK et al., 1991; MICHETTI et al., 1979), em análise periférica da barreira hemato encefálica de pacientes com metástase, que não apresentam sintomas neurológicos; esclerose lateral amiotrófica (MIGHETI et al., 1999); esquizofrenia (WEISMANN et al., 1999). Resultados semelhantes foram encontrados em casos de metástases viscerais, uma vez que a proteína atua também como elemento de regulação do 
crescimento celular por meio de duas ações: como molécula transdutora de sinais e como fator de transcrição nuclear (MIGHETI et al., 1999).

Pacientes têm apresentado aumento na concentração de S100ß após lesões traumáticas cerebrais, lesões cerebrais isquêmicas (ANDERSON et al., 2001b); acidentes vasculares (LAMERS et al., 1995; PERSSON et al., 1987); hemorragias subaracnóideas (PERSSON et al., 1988); isquemia aguda (BERTSCH et al., 2001; KIM et al., 1996); hipóxia cerebral (BERTSCH et al., 2001; ROSEN et al., 1998). Por seu teor estar aumentado durante alterações neurodegenerativas tem sido considerado como biomarcador desses eventos.

\subsection{Formação Hipocampal}

A formação hipocampal compreende 6 regiões citoarquitetonicamente distintas: hipocampo propriamente dito, Corno de Amomm (CA1, CA2, CA3); Giro Denteado (DG); Subiculo (S); Parasubiculo (PaS); Presubiculo (PrS) e Córtex Entorrinal (Ent) (AMARAL e WITTER, 1995).

O cortex entorrinal da formação hipocampal recebe densa aferência do bulbo olfatório principal e pela via perfurante envia projeções unidirecionais para o giro denteado, do qual projetam fibras para as camadas do hipocampo propriamente dito em CA3 e desta região (CA3), fibras são enviadas para as camadas do hipocampo em CA1 e então para o subículo, sempre de forma unidirecional (AMARAL e WITTER, 1995).

Células piramidais e células granulares, dois dos maiores tamanhos de neurônios da formação hipocampal, são encontradas no corno de Amomm e DG respectivamente. Células piramidais estão contidas em forma de " $C$ ", camada de célula curvada (camada piramidal) no corno de Amomm. A camada piramidal está subdividida entre as regiões CA1, CA2 e CA3. A região CA1 é algumas vezes conhecida como "região superior", enquanto que CA2 e CA3 como "região inferior". As células granulares contidas dentro deste giro também são arranjadas em camada em forma de "C", com o final aberto da forma "C" apontando na direção oposta do final aberto da forma "C" da camada piramidal (AMARAL e WITTER, 1995).

O hilo do DG, algumas vezes inapropriadamente e confusamente conhecida como região CA4 (AMARAL e WITTER, 1995), contem vários tipos 
de neurônios sendo as células mossy o tipo predominante. Lá existem neurônios que tem aparência similar com células piramidais da região CA3, mas podem ser distinguidas delas em virtude de sua localização espacial e da abrupta mudança na densidade (AMARAL e WITTER, 1995). As células piramidais no corno de Amomm e células mossy no hilus são geradas durante a última semana de gestação (BAYER, 1980a, b; SCHLESSINGER, 1978). Em contraste as células granulares do DG que se originam principalmente nas primeiras três semanas após nascimento (AMARAL e WITTER, 1995), mas continua sendo produzido, porem mais lentamente, no jovem adulto (KAPLAN e BELL, 1984, 1983; BAYER, 1980a, b).

O hipocampo é tipicamente descrito num contexto de circuito trisináptico, uma via que transmite informação da via perfurante do DG para a região CA3 e esta para a região CA1(SCHARFMAN, 2007). Associada a esse conceito está à suposição que este processamento de informação hipocampal ocorre ao longo do circuito trisináptico. De qualquer maneira, o córtex entorrinal pode não ser a única via de informação processada no hipocampo (SCHARFMAN, 2007). A região CA3 recebe impulsos de vários locais e poderia ser um "ponto de entrada" para o hipocampo assim como o DG. Os axônios de células piramidais de CA3 têm projeções comissurais, os quais juntos têm maior habilidade em dar informação ao hipocampo, do que as células granulares. Portanto células piramidais CA3 são mais bem vistas e designadas para propagar informação através do hipocampo do que células granulares (SCHARFMAN, 2007). Diante destas perspectivas CA3 poderia ser ponto de entrada na recepção de informação, que necessita ser "distribuída", enquanto que DG poderia ser um ponto de entrada na recepção de informação, porém "mais seletiva", para que ocorra melhor processamento hipocampal (SCHARFMAN, 2007).

Importante é observar, que a formação hipocampal é uma das áreas mais susceptíveis à morte neuronal após privação de oxigênio (ROGALSKA et al., 2006; CASOLINI et al., 2005; WAINWRIGHT et al., 2004; DELL'ANNA et al., 1995b). Alterações nessa região decorrentes de estímulos anóxicos podem resultar em déficits motores, cognitivos e distúrbios neuro-comportamentais, com prejuízo na aprendizagem e memória espacial (DELL'ANNA et al., 1997; IUVONE et al., 1996), que persistem por toda a vida. (CAPUTA et al., 2005; BUWALDA et al., 1995). 
2 OBJETIVOS 


\subsection{Enfoque da Pesquisa}

A partir da constatação da importância clinica da anóxia neonatal, de observações da literatura e de dados de nosso laboratório, evidenciando alterações neurais e comportamentais decorrentes da privação de oxigênio, decidimos explorar o envolvimento das células gliais nessa condição. Assim, optamos por avaliar a imunorreatividade da proteína $\mathrm{S} 100 \beta$, presente em astrocitos, por seu relatado papel trófico e marcador de dano no tecido nervoso. Escolhemos a formação hipocampal, por ser uma das regiões mais sensíveis à privação de oxigênio, bem como por sua relevância em processos cognitivos e de memória. Adotamos modelo animal, adaptado e validado por nosso laboratório. Com essas estratégias procuramos verificar a hipótese de que $\mathrm{S} 100 \beta$ deve apresentar acentuada imunorreatividade em astrocitos imediatamente após o estimulo, portanto pode ser considerado marcador desse dano, sendo que também objetivamos avaliar a persistência dessas alterações na glia em períodos de dias pós estimulo. 


\subsection{Objetivo Geral}

Pretendemos com técnicas de Imunoistoquímica, Imunofluorescência e de Western blot, analisar ratos neonatos nos grupos experimentais P2 e P7, nas condições experimentais: Basal (B), Sham (S) e Anóxia (A). Explorar as hipóteses de ativação de células da glia, astrócitos, pela privação de oxigênio no período neonatal, tanto em áreas envolvidas na regulação respiratória, a fim de validar o modelo, como em áreas da formação hipocampal relacionadas com memória e aprendizado, portanto eventual sitio de origem de alterações comportamentais observadas em animais adultos em nosso laboratório.

\subsection{Objetivos Específicos}

1- Avaliar os efeitos da anóxia, pela imunorreatividade da proteína $S 100 \beta$, em astrócitos de ratos neonatos, por análise quantitativa e análise de imagem em cortes coronais de animais submetidos à anóxia e processados com imunoistoquímica (técnica ABC/DAB) contra a proteína S100ß.

2- Avaliar a imunorreatividade $\mathrm{S} 100 \beta$, no núcleo do trato solitário (NTS), em ratos neonatos perfundidos com até 2 dias de vida (P2) após experimentos com diferentes intervalos de tempo (avaliação temporal: após 30 minutos; 2 horas e 7 horas).

3- Avaliar S100ß-IR, em regiões da formação hipocampal, em ratos neonatos perfundidos após experimentos, em diferentes dias de vida pós-estímulo (avaliação temporal de desenvolvimento do SNC: após 2 e 7 dias de vida, P2 e P7).

4- Avaliar a colocalização da imunofluorescência de GFAP com a proteína S100ß-IR. Identificar a localização dessas células imunorreativas e assim explorar os efeitos da anóxia em células da glia, em regiões da formação hipocampal.

5- Avaliar a expressão da proteína $S 100 \beta$, na formação hipocampal pelo método de Western blot, em ratos neonatos nos grupos P2 e P7, nas condições experimentais: Basal (B), Sham (S) e Anóxia (A). 
3 MATERIAL E MÉTODOS 


\subsection{Animais}

Utilizamos Rattus norvegicus da linhagem Wistar, provenientes do Biotério do Departamento de Anatomia do Instituto de Ciências Biomédicas III da Universidade de São Paulo. Os animais foram mantidos no biotério em condições controladas de umidade e temperatura $\left(21 \pm 22{ }^{\circ} \mathrm{C}\right)$, ciclo claro/ escuro de 12 horas (início do claro às 7:00 horas) com acesso à água e ração ad libitum. Os procedimentos descritos estão de acordo com as normas adotadas pelo Colégio Brasileiro de Experimentação Animal (COBEA) e foram aprovados pela Comissão de Ética em Experimentação Animal (CEEA), Protocolo no 134, folhas 38 do livro 2, de 11/2006.

\subsection{Delineamento experimental}

Casais de ratos com 60 dias de vida foram acasalados. Os ratos neonatos machos foram utilizados para compor os grupos estudados, os quais foram denominados de acordo com as condições experimentais a que foram submetidos: Basal (B), Sham (S) e Anóxia (A). Além dos diferentes tipos de estimulo (todos, sempre ocorrido entre 30/44 horas de vida pós-natal), cada grupo foi composto em estudo longitudinal, assim animais em diferentes períodos de espera, após o estimulo foram avaliados nas mesmas condições, nos grupos de ratos P2 e P7. Em ambos os grupos foram feitos estudos com técnicas de imunoistoquímica (Tabela 1), e Western blot (Tabela 2).

Tabela 1- Delineamento experimental, grupos avaliados por imunoistoquímica

\begin{tabular}{cccccc}
\hline Grupos & $\begin{array}{c}\text { Espessura } \\
\text { dos cortes }\end{array}$ & $\begin{array}{c}\text { Tempo de } \\
\text { espera } \\
\text { pós estimulo }\end{array}$ & $\begin{array}{c}\text { Região } \\
\text { do SNC }\end{array}$ & $\begin{array}{c}\text { Condição } \\
\text { experimental }\end{array}$ & $\begin{array}{c}\text { Numero de } \\
\text { animais }\end{array}$ \\
\hline P2 & $30 \mu \mathrm{m}$ & $\begin{array}{c}30 \text { minutos } \\
2 \text { e } 7 \text { horas } \\
\text { P2 }\end{array}$ & $10 \mu \mathrm{NTS}$ & B / S / A & $n=4$ \\
P7 & $10 \mu \mathrm{m}$ & $7^{0}$ dia & $\begin{array}{c}\text { Hipocampal } \\
\text { Formação } \\
\text { Hipocampal }\end{array}$ & B / S / A & $n=3$ \\
\hline
\end{tabular}

P2: ratos neonatos pós-natal, dois dias de vida; P7: sete dias de vida; NTS: Núcleo do Trato Solitário; Condição experimental: Basal (B), Sham (S) e Anoxia (A). 
Tabela 2- Delineamento experimental, grupos avaliados por Western blot

\begin{tabular}{cccccc}
\hline Grupos & $\begin{array}{c}\text { Delineamento } \\
\text { técnico }\end{array}$ & $\begin{array}{c}\text { Tempo de } \\
\text { espera } \\
\text { pós estimulo }\end{array}$ & $\begin{array}{c}\text { Região } \\
\text { do SNC }\end{array}$ & $\begin{array}{c}\text { Condição } \\
\text { experimental }\end{array}$ & $\begin{array}{c}\text { Numero de } \\
\text { animais }\end{array}$ \\
\hline P2 & $\begin{array}{c}\text { decaptação/ } \\
\text { dissecação } \\
\text { decaptação } \\
\text { dissecação }\end{array}$ & 2 horas & $\begin{array}{c}\text { Formação } \\
\text { Hipocampal } \\
\text { Formação } \\
\text { Hipocampal }\end{array}$ & B / S / A & $n=8$ \\
\hline
\end{tabular}

P2: neonatos, dois dias de vida pós-natal; P7: sete dias de vida; Condição experimental: Basal (B), Sham (S) e Anoxia (A); numero de animais: amostras formadas por 2 ratos machos em cada grupo e em cada condição experimental, técnica Western blot.

\subsubsection{Condição Basal (B)}

Utilizamos animais P2 (com 30/44 horas de vida, aproximadamente) e animais P7 (com sete dias de vida), que não foram submetidos a qualquer forma de manipulação. Logo após serem retirados do convívio da mãe (com 2 e 7 dias de vida, respectivamente), foram profundamente anestesiados, seguido de perfusão transcardíaca, os encéfalos foram removidos, criosseccionados e processados por técnicas imunoistoquímica $A B C-D A B$; ou decapitados, encéfalos removidos, dissecado o hipocampo e processados por técnicas de Western blot.

\subsubsection{Condição "Sham” (S)}

Utilizamos animais P2 (com 30/44 horas de vida, aproximadamente) e animais P7 (com sete dias de vida), que foram submetidos à "simulação" na câmara, ora denominado "Sham" (S). Consistiu da entrada do rato neonato na câmara semi-hermética, não sendo expostos a alterações da composição do ar, ou seja, ao nitrogênio gasoso 100\% e ali permaneceram por 25 minutos (mesma duração que o grupo anóxia).

O grupo P2 conforme proposta:

* animais do grupo P2 2 horas, utilizados somente para estudo em regiões da Formação Hipocampal por imunoistoquímica.

* animais em outro grupo P2 2 horas, utilizado para estudo da Formação Hipocampal pelo método Western blot. 
* um terceiro lote de animais do grupo P2, subdividido em grupos de 2 horas e 7 horas, conforme proposta: estudo imunoistoquímico para avaliação da dinâmica de expressão de S100ß no Núcleo do Trato Solitário;

= o grupo 2 horas, não retornaram à gaiola materna (permaneceram aguardando na gaiola em outra sala, de forma a minimizar o efeito de qualquer odor/ruído contido na sala de experimentação), quando então foram profundamente anestesiados e perfundidos (ou seja, duas horas após procedimento "sham"), os encéfalos foram removidos, criosseccionados e processados por técnicas imunoistoquímica ABC-DAB; ou decapitados, dissecados e processados por técnicas de Western blot.

= o grupo 7 horas, retornaram às gaiolas maternas até o momento previsto (ou seja, 7 horas, após procedimentos "Sham"), quando foram profundamente anestesiados, perfundidos, criosseccionados e processados pelo método imunoistoquímica.

O grupo P7 conforme proposta: avaliação da expressão dinâmica de S100ß em regiões da Formação Hipocampal, após procedimentos simulados, "Sham", com aproximadamente 30/44 horas de vida, retornaram às gaiolas maternas, aguardando o sétimo dia de vida, quando então foram profundamente anestesiados e perfundidos, sendo então processados por técnicas imunoistoquímica ABC-DAB; ou por técnicas de Western blot.

\subsubsection{Condição Anóxia (A)}

Foram utilizados animais com dois dias de vida, aproximadamente 30/44 horas pós-natal, quando então foram submetidos à anóxia, esta consistiu da entrada do rato neonato na câmara semi-hermética foram exposto a nitrogênio gasoso (100\%) e ali permaneceram por 25 minutos, seguido de ressuscitação quando necessário (consistiu em massagear o coração e sopros nas narinas do animal).

O grupo P2 conforme proposta:

* um grupo P2 2 horas, utilizado somente para estudo em regiões da Formação Hipocampal pelo método imunoistoquímico.

* outro grupo P2 2 horas, utilizado para estudo da Formação Hipocampal pelo método Western blot. 
* um terceiro lote de animais do grupo P2, a qual foi subdividido em grupos de: 2 horas e 7 horas, conforme proposta: estudo imunoistoquímico da avaliação da expressão dinâmica de S100ß no Núcleo do Trato Solitário;

= o grupo 2 horas, não retornaram à gaiola materna (permaneceram aguardando na gaiola em outra sala, de forma a minimizar o efeito de qualquer odor contido na sala de experimentação), quando então foram profundamente anestesiados e perfundidos (ou seja, duas horas após procedimento "anóxico"), os encéfalos foram removidos, criosseccionados e processados por técnicas imunoistoquímica $\mathrm{ABC} / \mathrm{DAB}$; ou decapitados, dissecados e processados por técnicas de Western blot.

= o grupo 7 horas, retornaram às gaiolas maternas até o momento previsto (ou seja, 7 horas, após procedimentos de anóxia), quando então foram profundamente anestesiados e perfundidos criosseccionados e processados pelo método imunoistoquímico.

O grupo P7 conforme proposta: avaliação da expressão dinâmica de S100ß em regiões da Formação Hipocampal, após procedimentos "anóxico", com aproximadamente 30/44 horas de vida, retornaram às gaiolas maternas, aguardando o sétimo dia de vida, quando então foram profundamente anestesiados e perfundidos, sendo então processados por técnicas imunoistoquímica ABC/DAB; ou por técnicas de Western blot.

\subsection{Condições Experimentais}

Aos animais que foram submetidos a procedimentos anóxicos (nitrogênio gasoso 100\%), foi utilizada uma câmara semi-hermética de policarbonato com 31,0 × 14,0 × 19,5 cm com uma entrada e saída de gás, acoplada ao manômetro, fluxômetro e ao cilindro de nitrogênio gasoso (TAKADA et al., 2011).

Para a manutenção da temperatura dos neonatos, a câmara aquecida por resistência elétrica, fica parcialmente imersa em água a $35 \pm 37^{\circ} \mathrm{C}$ (esta faixa de temperatura é importante para potencializar os efeitos de anóxia), pois a temperatura basal dos neonatos é de $33^{\circ} \mathrm{C}$, o que constitui um fator de neuroproteção (ROGALSKA et al., 2006; CAPUTA et al., 2005). 
Figura 3- Sistema utilizado para provocar anóxia nos ratos neonatos

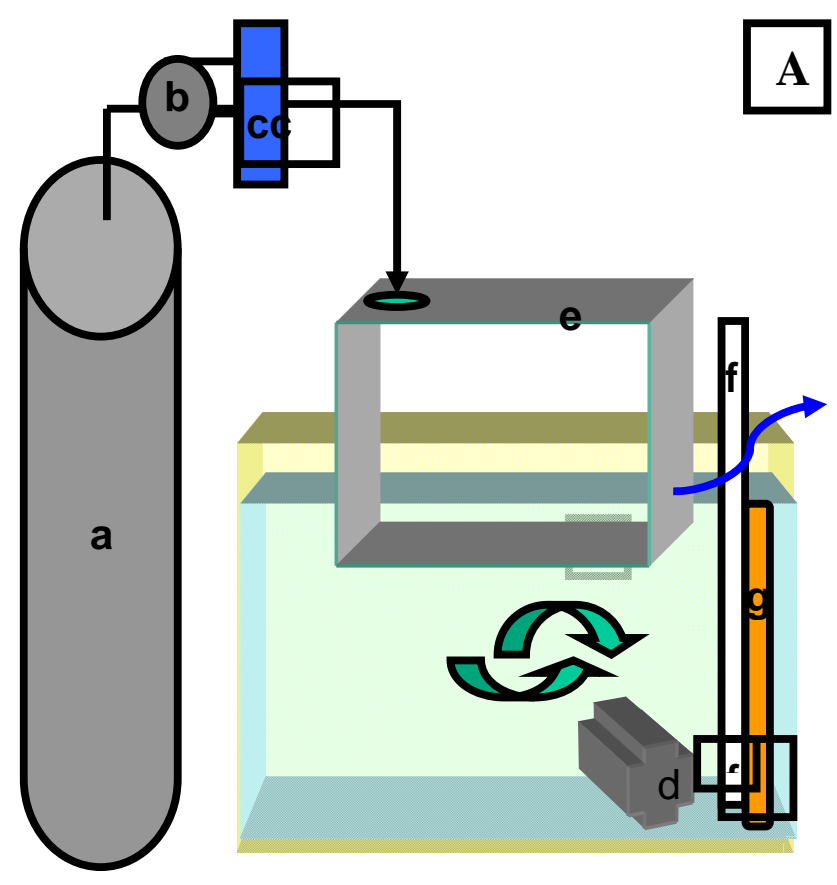

A: Desenho esquemático:

a - cilindro de nitrogênio gasoso (concentração de 100\%);

b - manômetrro;

c - fluxômetro;

d - bomba difusora de água (homogeneizar a temperatura da água);

e - câmara em policarbonato parcialmente imersa na água;

f - termômetro;

g - resistência aquecimento da água;

seta preta - entrada de gás; seta azul - saída do gás.

Fonte: modificado de TAKADA et al. (2011).

Primeiramente a câmara foi saturada completamente com nitrogênio 100\% (um minuto é mais que suficiente para total saturação e/ou substituição de oxigênio outrora ali contido, por nitrogênio ora colocado) com fluxo de 3L/minuto e pressão de 101,7 kPa (TANG e NAKAZAWA, 2005; ROGALSKA et al., 2004). Desse modo, a concentração de oxigênio na câmara chega praticamente à zero, caracterizando anóxia, uma vez que a total substituição do ar ambiente, de dentro da câmara, para as condições de anóxia requer menos que a fração de minuto (ROGALSKA et al., 2004) (Figura 3).

Os animais foram colocados na câmara, repleta de nitrogênio gasoso, permanecendo durante 25 minutos nestas condições, tempo este considerado, para que não ocorra morte aos ratos neonatos. $O$ índice de mortalidade nas 
condições anóxicas é descrito como igual a 12,5\% (TAKADA et al., 2011; IUVONE et al., 1996; DELL'ANNA et al., 1995; 1991).

Cuidado adicional com a câmara foi à limpeza (processo de anti-sepsia) com álcool $70 \%$ entre um animal e outro (pois foram submetidos a esse experimento, individualmente), para que odores de urina ou fezes não denunciem qualquer fato ali ocorrido. Os animais foram mantidos em ante-sala, sendo que, um animal de cada vez foi introduzido na sala de experimentação.

O modelo experimental escolhido para provocar anóxia em neonatos, foi adaptado da literatura (ROGALSKA et al., 2006; TANG e NAKAZAWA, 2005; CAPUTA et al., 2005; LAVIOLA et al., 2004; DELL'ANNA et al., 1997; IUVONE et al., 1996; BUWALDA et al., 1995), e validado por nosso grupo de pesquisa (TAKADA et al., 2011).

3.4 Processamento do Material Biológico para Imunoistoquímica: Perfusão e Microtomia (Criostato)

Para estudo dos segmentos histológicos, os animais P2 e P7 foram submetidos à perfusão com soluções salina e fixadora, conforme procedimento usual de nosso laboratório (NOGUEIRA et al., 1997), seguido de microtomia.

Os animais que foram submetidos à perfusão, foram profundamente anestesiados com administração intraperitoneal de hidrato de cloral a 35\% (dose letal). Após comprovação do grau da anestesia, os animais foram posicionados na prancha de perfusão e o coração foi exposto por remoção da parede anterior da caixa torácica. Por perfusão transcardíaca, foram injetados: solução salina ( $\mathrm{NaCl}$ a $0,9 \%$, Synth) seguida de solução fixadora de $4 \%$ de formaldeído (Synth), diluído em tampão fosfato $0,1 \mathrm{M}$ e bórax 3,8\% (Synth) pH 9,5 a $4{ }^{\circ} \mathrm{C}$ (este, torna a solução mais alcalina, e é considerado protetor de proteínas), até ser observado mudança na coloração do animal e contração muscular dos membros, evidenciando a correta penetração do fixador. Para preservar a natureza química das substâncias protéicas, a cabeça do animal foi coberta com gelo picado.

Após a perfusão, os encéfalos foram dissecados e pós-fixados em solução fixadora mais sacarose a $20 \%$ a $4{ }^{\circ} \mathrm{C}$, por um período de 4 horas. Em seguida os encéfalos foram colocados em recipientes de crioproteção 
(overnight) contendo solução diluída em tampão fosfato de sódio (PBS) $0,1 \mathrm{M}$ $\mathrm{pH} 7,4$, mais sacarose a $20 \%$ a $4{ }^{\circ} \mathrm{C}$, em seguida imersos em solução OCT (Tissut-Tek) e armazenados em freezer $-80^{\circ} \mathrm{C}$ até o momento da criossecção.

$\mathrm{Na}$ criossecção, o encéfalo foi cortado em criostato (Leica, CM 1850), com temperatura variando entre $-22^{\circ} \mathrm{C} \mathrm{e}-24{ }^{\circ} \mathrm{C}$. A espessura dos cortes foi de $30 \mu \mathrm{m}$ e $10 \mu \mathrm{m}$ conforme estudos preliminares que indicaram beneficio dependendo do objetivo em relação às reações de imunoistoquímica. Entretanto, dentro de um mesmo grupo experimental a espessura foi constante.

Nos cortes frontais de $30 \mu \mathrm{m}$ de espessura nos animais P2 2 horas e 7 horas (conforme proposta: avaliação da dinâmica de expressão de S100ß no Núcleo do Trato Solitário), foram obtidas 3 séries de cortes consecutivos, portanto com $90 \mu \mathrm{m}$ de distância entre um corte e outro).

Nos cortes coronais de $10 \mu \mathrm{m}$ de espessura para o grupo P2 2 horas e P7 (conforme proposta: avaliação da expressão dinâmica de $S 100 \beta$ em regiões da Formação Hipocampal), foram obtidas 9 séries aos animais P2 2 horas e 12 séries aos animais P7 (cortes consecutivos, com $90 \mu \mathrm{m}$ e $120 \mu \mathrm{m}$ de distância um corte do outro, respectivamente).

Os cortes coronais de $30 \mu \mathrm{m}$ e $10 \mu \mathrm{m}$ de espessura foram processados em lâminas gelatinizadas (Aldrich) e coletados em séries, em ordem crâniocaudal. Em seguida armazenados no freezer $\left(-20^{\circ} \mathrm{C}\right)$ em recipiente protegido de umidade, até o momento adequado para as reações de imunoistoquímica e/ou imunofluorescência.

\subsubsection{Titulação de anticorpos primários: S100ß e GFAP}

Para início dos experimentos, em procedimentos de técnica de imunoistoquímica, efetuamos a titulação de anticorpo primário, para obter informação da melhor quantidade de anticorpo numa determinada concentração, com o objetivo de minimizar marcações inespecíficas em animais anoxiados, nos grupos P2 e P7, processados pelo método de imunoperoxidase (ABC/DAB), para as proteínas, S100ß e GFAP. 
3.5 Método de Imunoistoquímica: S100ß-IR

Os animais, grupos P2 e P7, nas condições experimentais (B, S e A) montados em lâminas, foram processados pelo método de imunoperoxidase $(A B C / D A B)$ de forma a visualizar e estudar as células $S 100 \beta$ imunorreativas, nas regiões da Formação Hipocampal e Núcleo do Trato Solitário.

Primeiramente as laminas foram lavadas em PBS (três vezes de 10 minutos cada), em seguida o tecido foi mergulhado por segundos em solução, contendo PBS $(0,1 \mathrm{M}$ pH 7,4$)$ e água oxigenada $\left(\mathrm{H}^{2} \mathrm{O}^{2}\right.$ a 0,03\%). Novamente os cortes foram lavados em PBS (três vezes de 10 minutos cada), até que todas as bolhas formadas fossem retiradas. Em seguida o tecido foi incubado em

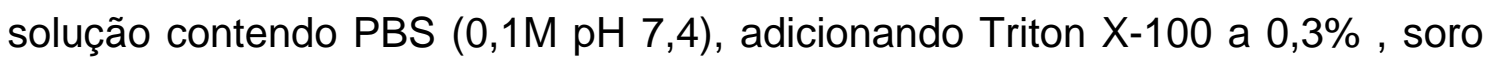
normal de cabra (NGS) a 2\% (Vector Laboratories, Burlingame, CA, EUA) e anticorpo primário S100ß, (monoclonal mouse anti-S100 $\beta$ [1:10000] - Protos Biotech) sendo acondicionado por $24 / 48$ horas a $4{ }^{\circ} \mathrm{C}$.

Os cortes seguiram procedimentos de lavagens com PBS e foram incubados com o anticorpo secundário biotinilado (Biotin-Goat Anti-Mouse [1:1000] - Vector Laboratories, Burlingame, CA, EUA), diluído em Triton X-100 a $0,3 \%$ e PBS $(0,1 \mathrm{M}$ pH 7,4), por 90 minutos. Após novas lavagens com PBS, o tecido foi incubado no complexo avidina-biotina (ABC-Vectastain Kit Elite, Vector Laboratories, Burlingame, CA, EUA) na concentração de 1:500 diluído em PBS, por 90 minutos. Após novas lavagens com PBS, a reação de imunoperoxidase foi realizada com cromógeno, DAB (3-3' - diaminobenzidina tetrahidrocloreto - Sigma - Aldrich, St. Louis, MO, EUA) diluído em PBS, adicionando sulfato de amônio e níquel (Sigma), seguido da adição de hidróxido de peróxido $\left(\mathrm{H}^{2} \mathrm{O}^{2}\right.$, a $\left.0,03 \%\right)$ na solução, a reação foi interrompida com lavagens em PBS.

Os cortes (caso necessário) foram submetidos à osmicação para contraste de coloração. Este consistiu em imergir os cortes em recipiente contendo água destilada, a seguir em solução de tetróxido de ósmio por 20 segundos, seguidos de desidratação em séries crescentes de alcoóis, em seguida deslipidificação em xilol (Synth). As lâminas foram recobertas com lamínula e DPX (BDH Lab. Supplies) como meio de montagem, deixadas secar à temperatura ambiente. 
3.6 Método Imunofluorescência em lâmina: Dupla marcação S100ß, GFAP

Utilizamos método de imunofluorescência, para detecção da expressão e possível colocalização de $S 100 \beta$ com GFAP, nos grupos P2 e P7, nas condições $B$, S e A, na região CA3+CA2, do Hipocampo.

Os cortes coletados em lâminas permaneceram por 15 minutos em placa quente a $32{ }^{\circ} \mathrm{C}$. Em seguida o tecido foi incubado em solução contendo

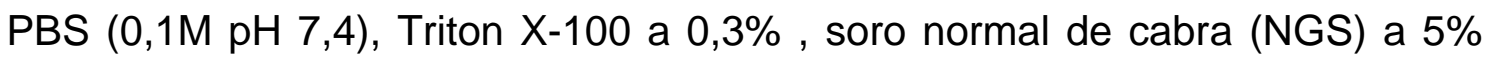
(Vector Laboratories, Burlingame, CA, EUA), e anticorpos primário S100ß, (monoclonal Mouse Anti-S100ß [1:5000] - Protos Biotech), e GFAP, (policlonal Rabbit Anti-GFAP [1:1000] - Protos Biotech), acondicionados 24 horas a $4{ }^{\circ} \mathrm{C}$.

Os cortes seguiram procedimentos de lavagens em PBS. Estes foram incubados durante o período de 120 minutos à temperatura ambiente, com os anticorpos secundário: (a), anticorpo secundário fluorescente, CY3 (Goat, AntiMouse [1:200] - Vector Laboratories, Burlingame, CA, EUA), com espectro de emissão com feixe de luz vermelha; (b) anticorpo secundário fluorescente, DAYLYGHT (Goat, Anti-Rabbit [1:200] - Vector Laboratories, Burlingame, CA, EUA), com espectro de emissão com feixe de luz verde, ambos diluídos em

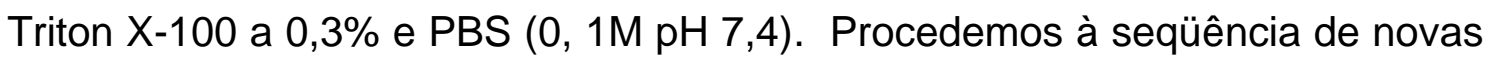
lavagens em PBS. As lâminas foram recobertas com lamínula utilizando Vectashield Mounting Médium (Vector Laboratories, USA) como meio de montagem e vedadas com esmalte, em seguida acondicionadas em caixa fechada (sem luz) contendo sílica como prevenção à umidade, e mantida em geladeira a $4{ }^{\circ} \mathrm{C}$.

A imunorreatividade foi analisada ao microscópio de luz e ao microscópio Nikon Eclipse 80i equipado com epifluorescência e câmera digital Nikon DXM 1200F.

\subsection{Método de Western blot na Formação Hipocampal}

Utilizamos a técnica de Western blot para quantificação da proteína S100ß na Formação Hipocampal, nos grupos P2 e P7 nas condições experimentais $B, S$ e $A$.

Os animais foram mortos por decaptação e rapidamente dissecados, a Formação Hipocampal extraída sob lupa estereoscópica e as porções direita e 
esquerda de cada animal foram imediatamente colocada em microtubos, mantidos em nitrogênio liquido e em seguida acondicionados em freezer $-80{ }^{\circ} \mathrm{C}$ até o procedimento de extração de proteínas totais. Em cada amostra foi realizado um "pool" de dois animais do mesmo grupo e da mesma condição experimental, para alcançar uma quantidade suficiente de proteína.

A extração das proteínas foi realizada com tampão de extração a frio e homogeneizado a 19000rpm com Polytron (Kinematica AG, Suiça), após essa etapa foi adicionado ao homogenato $10 \%$ do volume do tampão de extração de tritron X-100 10\% e mantido em gelo por 30 minutos. A separação foi realizada em centrifuga a $4{ }^{\circ} \mathrm{C}, 12000 \mathrm{rpm}$, por 20 minutos. O conteúdo protéico total do sobrenadante isolado foi dosado pelo método de Bradford (Amresco, USA). Após essa quantificação, os materiais foram diluídos em um mesmo volume de tampão Laemmli (Bio-Rad, USA), contendo 0,01 mg/ml de DTT (Sigma, USA), as amostras foram posteriormente fervidas em banho maria por 5 minutos e 0 material foi aplicado em gel de poliacrilamida a 10\% e submetido a eletroforese com corrente contínua de $120 \mathrm{~V}$. Os volumes de amostra, carregados em cada poço, foram ajustados (a partir da quantificação, ABS por Espectrofotometria) para que a mesma quantidade de proteína $(75 \mu \mathrm{g})$ fosse alcançada.

Após a separação eletroforética, as proteínas foram eletro-transferidas para membranas de nitrocelulose (Millipore, 0,2 $\mu \mathrm{m}$ de diâmetro) de acordo com a técnica descrita por Towbin et al., (1979). Os antígenos presentes na membrana de nitrocelulose foram submetidos à caracterização imunoenzimática. Após bloqueio com leite desnatado (Molico, Nestlé) 5\% em tampão Tris-Salina (Tris 10mM e $\mathrm{NaCl}$ 0,15M, pH 7,5), por 20 minutos, as membranas foram lavadas com Tris-Salina e incubadas com anticorpos para 0 reconhecimento da proteína S100ß, (monoclonal Mouse Anti-S100 $\beta$ [1:1000] Protos Biotech), em solução bloqueadora (1\% de BSA) por 18 horas a $4{ }^{\circ} \mathrm{C}$. Em seguida, as membranas foram lavadas com Tris-Salina e incubadas por 90 minutos com o anticorpo secundário conjugado com peroxidase de raiz forte (MS HRP [1:3000] Amersham Biosciences, NJ/EUA). O excesso foi removido com mais de um ciclo de lavagens com Tris-Salina. A $\beta$-actina foi utilizada como controle interno da reação (monoclonal Mouse Anti- $\beta$-actina [1:10000] Sigma, USA). As membranas foram reveladas utilizando o Kit ECL (Amershan Biosciences, NJ/EUA) de quimioluminescência e foram analisadas quanto à 
densidade óptica das bandas, com o programa Scion Image (Scion Corporation, Frederick, MD/EUA). A análise dos dados foi feita pela média das diferenças percentuais entre os diferentes grupos e condições experimentais.

\subsection{Métodos para Análise Quantitativa no Núcleo do Trato Solitário}

A análise histológica no NTS foi realizada em microscopia de campo claro utilizando objetiva com aumento 10X, com o auxílio do ATLAS PAXINOS, ASHWELL e TORK, 1998, (Atlas de Desenvolvimento do Sistema Nervoso de Ratos), juntamente com uma série corada com tionina $(0,25 \%)$, através da técnica em Nissl.

Foram analisadas e quantificadas as células S100ß-IR com marcação evidente seguindo a seguinte padronização:

* As imagens foram capturadas por câmera digital (Cool SNAP-Pro, Media Cybernetics, Silver Spring, MA.EUA) acoplada a um microscópio (E-1000, Nikon, Melville, NY, EUA), através de um programa de análise de imagem (Image Pro-Plus) instalado no microcomputador.

* Análise quantitativa da área selecionada, região do núcleo do trato solitário (NTS), em ratos neonatos grupo P2 2 horas e 7 horas, nas condições B, S e A. (Figura 4)

Figura 4- Identificação do Núcleo do Trato Solitário no encéfalo

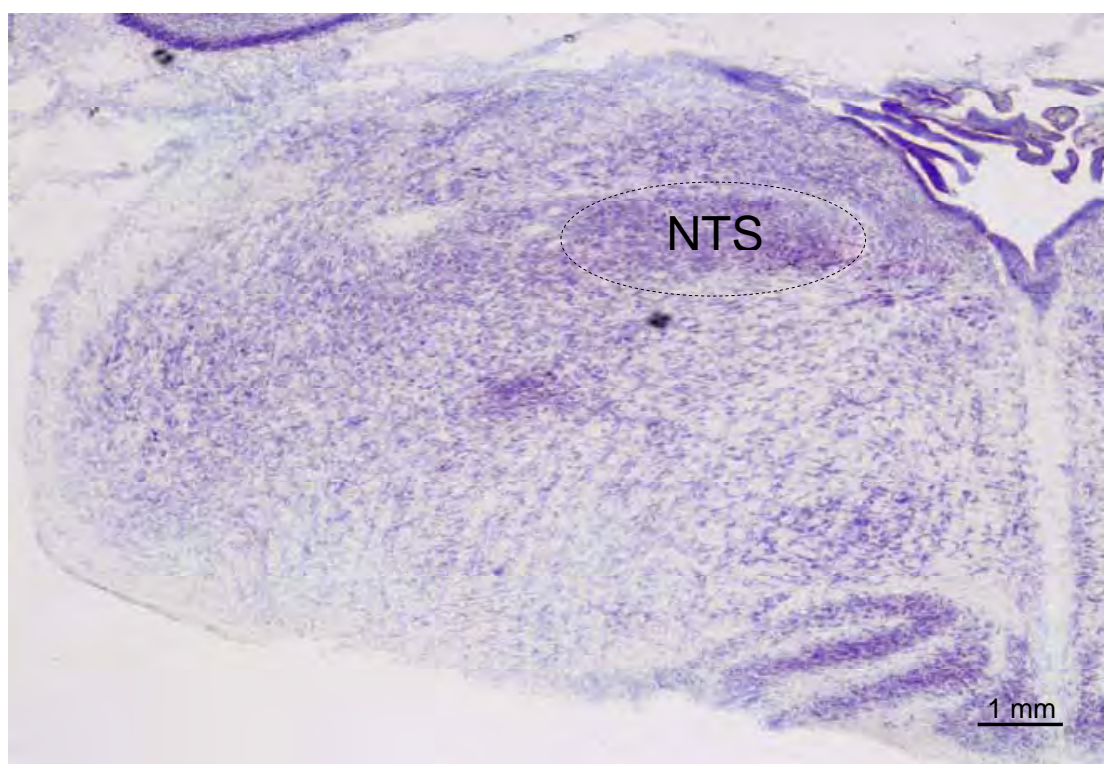

Fotomicrografia de coloração em Nissl, do Núcleo do Trato Solitário: Delineamento pontilhado indica a região (NTS) estudada nas análises, de rato neonato, P2, em condição basal. Nível -13.00 mm a partir do Bregma. Barra $1 \mathrm{~mm}$.

Fonte: Allemandi, (2011). 
* Com o Programa Image Pro-Plus, "polígono irregular" como ferramenta, este núcleo foi "contornado", em secções consecutivas ao longo do eixo anteroposterior, a partir do Bregma $-14.00 \mathrm{~mm}$ a $-10.00 \mathrm{~mm}$, correspondentes às figuras 202 até 216, conforme Atlas de PAXINOS, ASHWELL e TORK. Obtivemos diferentes tamanhos de "contornos" ao longo do eixo anteroposterior.

* Com as imagens, da imunorreatividade do campo selecionado, capturadas e armazenadas na memória do computador, esses "contornos" foram sobrepostos em cada fotomicrografia de igual nível.

* Com o auxilio de sistema de projeção, câmara acoplada a um microscópio, a imagem da secção, juntamente com os "contornos", puderam ser projetados no monitor, onde foram efetuadas as contagens das células ali contidas (Figura 5).

Figura 5- Fotomicrografia de S100ß-IR no Núcleo do Trato Solitário

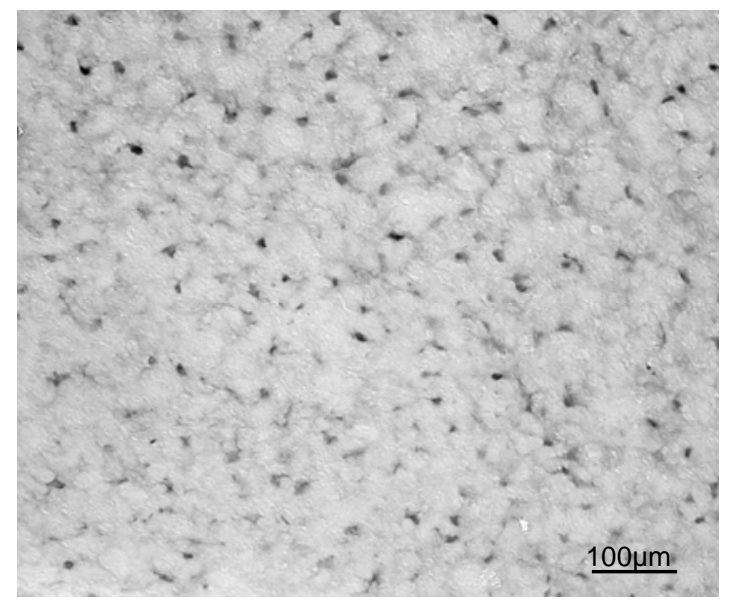

Indica parte da região selecionada e avaliada na quantificação das células. Imagem de rato grupo P2 B. Nível -13.00 mm a partir do Bregma. Barra $100 \mu \mathrm{m}$.

Fonte: Allemandi, (2011).

\subsection{Métodos para Análise Quantitativa na Formação Hipocampal}

Para quantificação do número de células $\mathrm{S} 100 \beta-\mathrm{IR}$ em regiões da Formação Hipocampal, a análise histológica foi realizada em microscopia óptica de campo claro (modelo Hund Wetzlar H-500), no qual foi adaptado um retículo quadriculado (de 0,5 $\mu \mathrm{m}$ ), na lente ocular confeccionado especialmente para esse fim, por especialista. 
Utilizamos objetiva com aumento 20X, com o auxílio do Atlas PAXINOS, ASHWELL e TORK, 1998, (Atlas de Desenvolvimento do Sistema Nervoso de Ratos), juntamente com uma série corada com tionina (0,25\%), técnica em Nissl.

Figura 6- Quantificação de células S100ß-IR na Formação Hipocampal

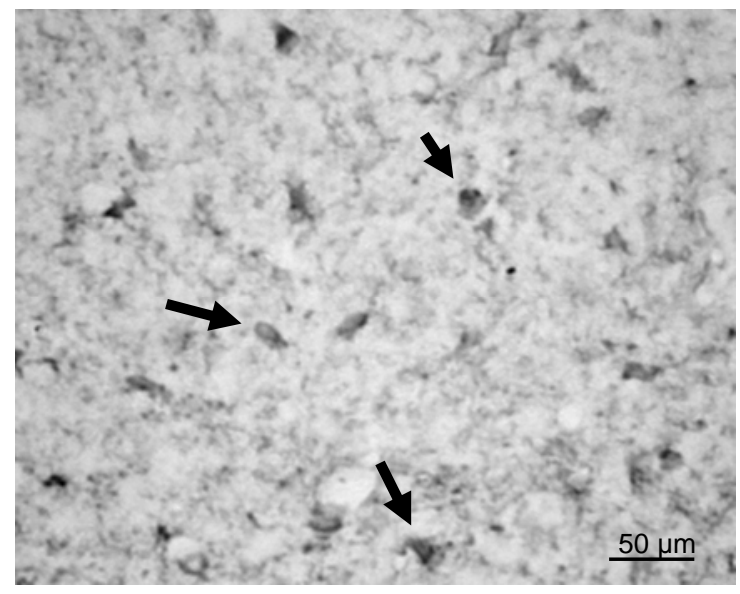

Região do hipocampo propriamente dito, células consideradas na contagem, indicadas por seta. Imagem rato grupo P7, condição A. Barra 50 um. Nível -3.30 mm a partir do Bregma.

Fonte: Allemandi, (2011).

* Foram analisadas, selecionadas e quantificadas cinco secções histológicas, de $10 \mu \mathrm{m}$ cada, e consideradas somente as células S100ß-IR visíveis e de coloração evidente (Figura 6).

* Realizamos análise quantitativa da área selecionada: região do Giro Denteado (DG) da Formação Hipocampal e regiões CA1 e CA3+CA2 do Hipocampo propriamente dito, em ratos neonatos, grupos P2 2 h e P7, na condição Basal (B), Sham (S) e Anóxia (A) (Figura 7). Posicionamos os cortes histológicos dos núcleos estudados, ao longo do eixo antero-posterior, da figura 168 até 172, (nível -3,30 mm a -3,80 mm, a partir do Bregma), conforme Atlas de PAXINOS, ASHWELL e TORK, 1998 (Atlas de Desenvolvimento do Sistema Nervoso de Ratos). 
Figura 7- S100ß-IR e camadas das regiões da Formação Hipocampal

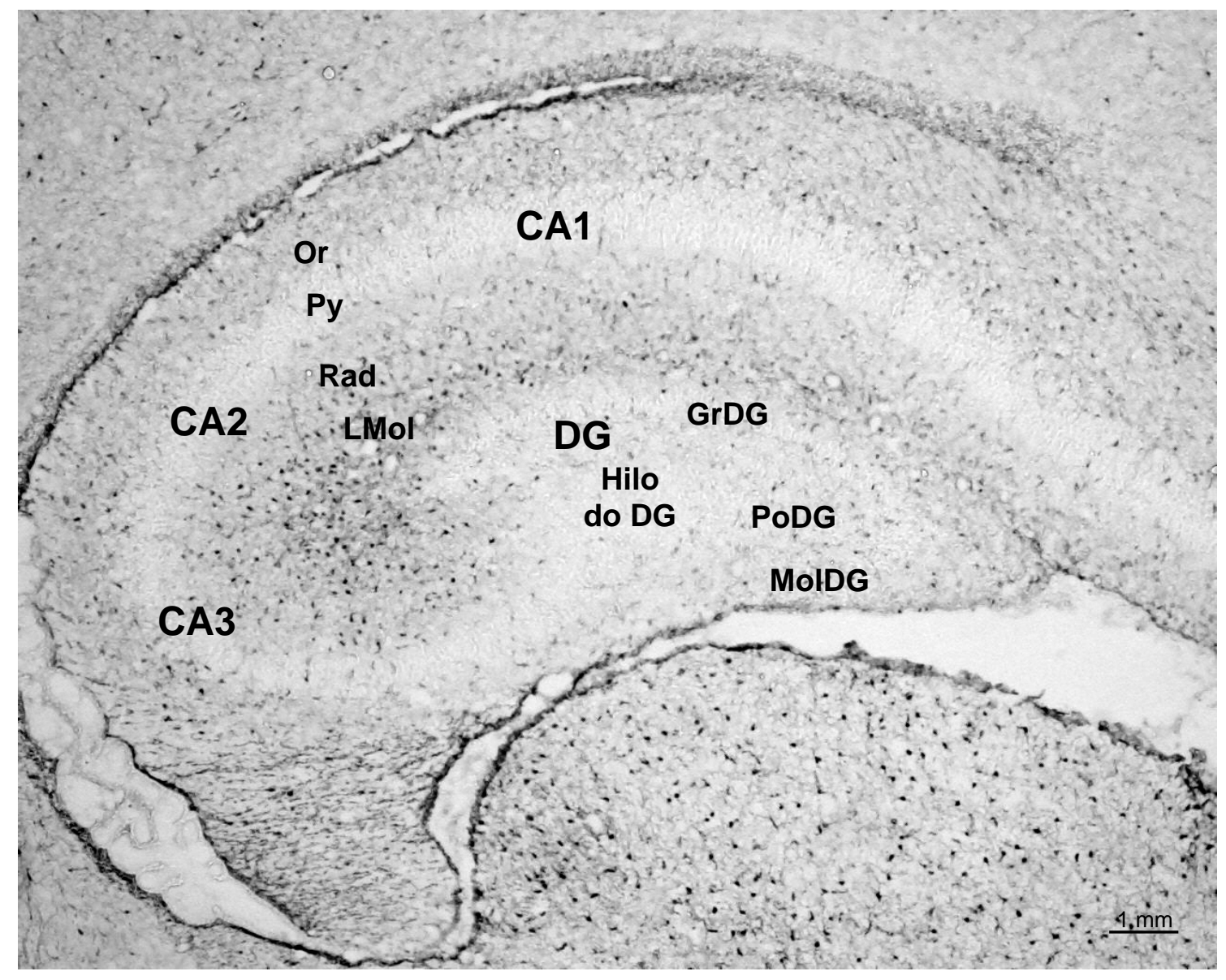

Fotomicrografia em campo claro,camadas de regiões da Formação Hipocampal. Imagem em rato grupo P2, condição A. Barra $1 \mathrm{~mm}$. Nível $-3.30 \mathrm{~mm}$ a partir do Bregma.

Fonte: Allemandi, (2011).

* A imagem da secção juntamente com o "box", formado pelo retículo, sobreposto em cada nível histológico, foram visualizados pela ocular do microscópio, onde foram amostradas regiões especificas de nosso estudo, permitindo a contagem das células ali contidas.

* Retículo de 0,5 $\mu \mathrm{m}$ na lente ocular é ferramenta para quantificação S100ß-IR.

* Dimensões do retículo: (avaliada por régua milimetrada) (Figura 8).

O retículo, na sua totalidade, contém 20 "células" em comprimento por 20 "células" em altura, formando uma figura geométrica quadrada, grade com 400 células, sendo que cada célula possui $1 \mu \mathrm{m}$.

A -- Para quantificarmos S100ß-IR, no animal P2 utilizamos 18X18 células (total de 324 células, formando uma grade de $324 \mu \mathrm{m}^{2}$ ou $0,32 \mathrm{~mm}^{2}$ ).

B -- Para quantificarmos S100ß-IR, no animal P7 utilizamos 20X20 células (total de 400 células formando uma grade de $400 \mu \mathrm{m}^{2}$ ou $0,40 \mathrm{~mm}^{2}$ ). 
Figura 8 - Esquema do Retículo
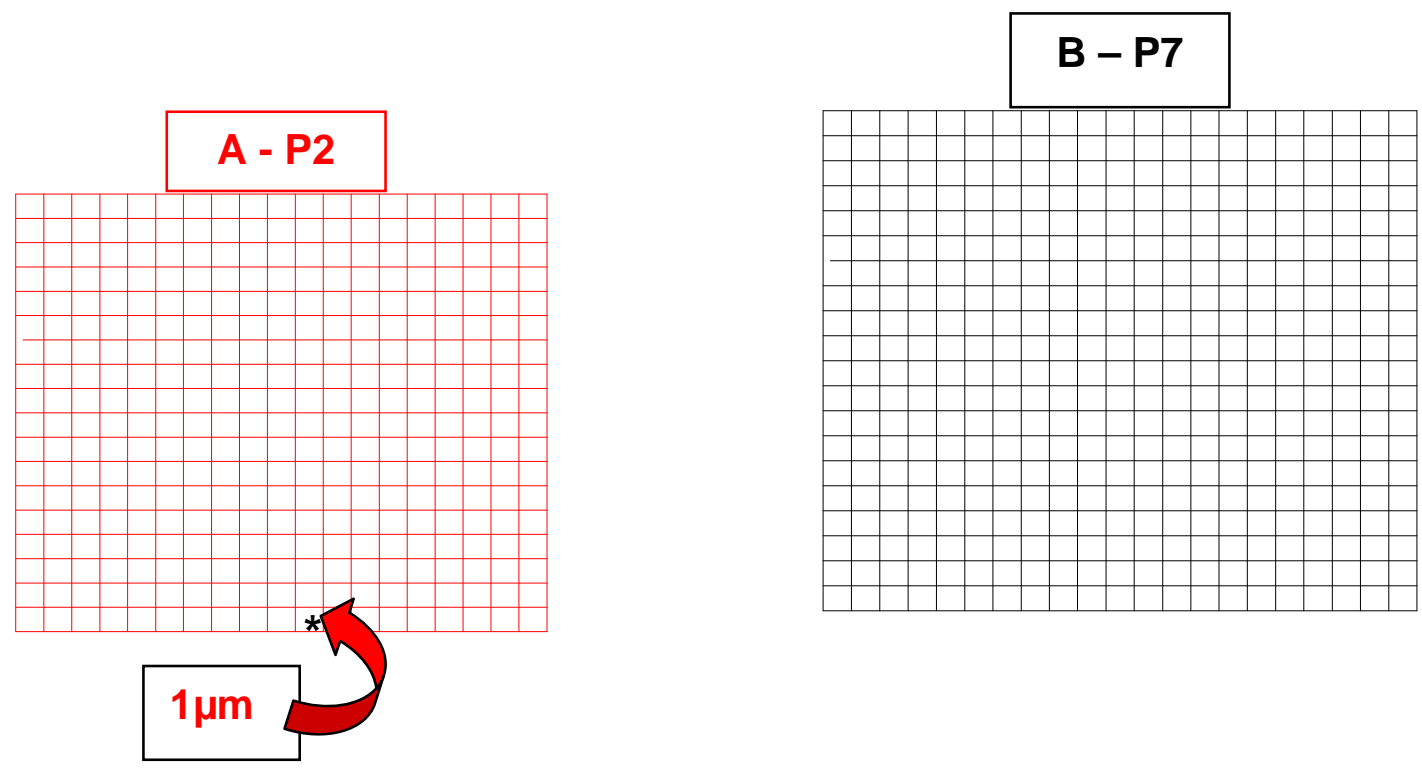

Ferramenta utilizada para quantificar células S100ß-IR. (A), representa área utilizada no rato $\mathrm{P}$ 2, retículo com $324 \mu \mathrm{m}^{2}$ ou $0,32 \mathrm{~mm}^{2}$. (B), representa área utilizada no rato $\mathrm{P} 7$, retículo com $400 \mu \mathrm{m}^{2}$ ou $0,40 \mathrm{~mm}^{2}$.

Fonte: Allemandi, (2011).

Figura 9- Fotomicrografia em Nissl com esquema das camadas quantificadas das regiões da Formação Hipocampal

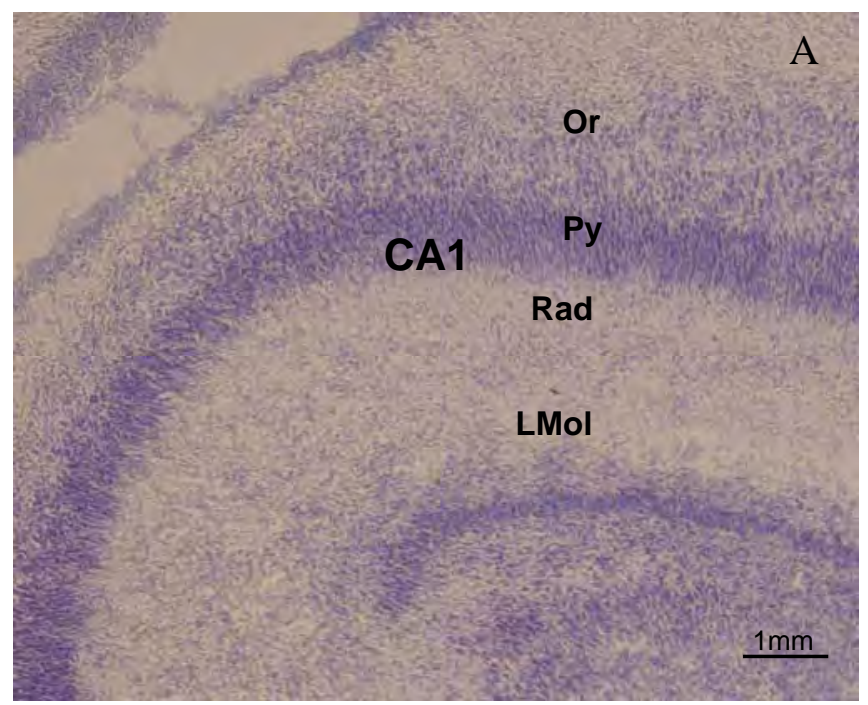

Amostra A. Região do Corno Ammon CA1 (Corno Ammonis1) incluídas e quantificadas as seguintes camadas: camada de orientação, Or (Stratum Oriens); camada piramidal, Py (Stratum Pyramidale); camada radiada, Rad (Stratum Radiatum); camada molecular-lacunosa, LMol (Stratum Moleculare-Lacunosum). Nível $-3,30 \mathrm{~mm}$ a partir do Bregma. Barra $1 \mathrm{~mm}$.

Fonte: Camadas modificado de Atlas PAXINOS, ASHWELL e TORK (1998).

Fonte: Allemandi, (2011). 


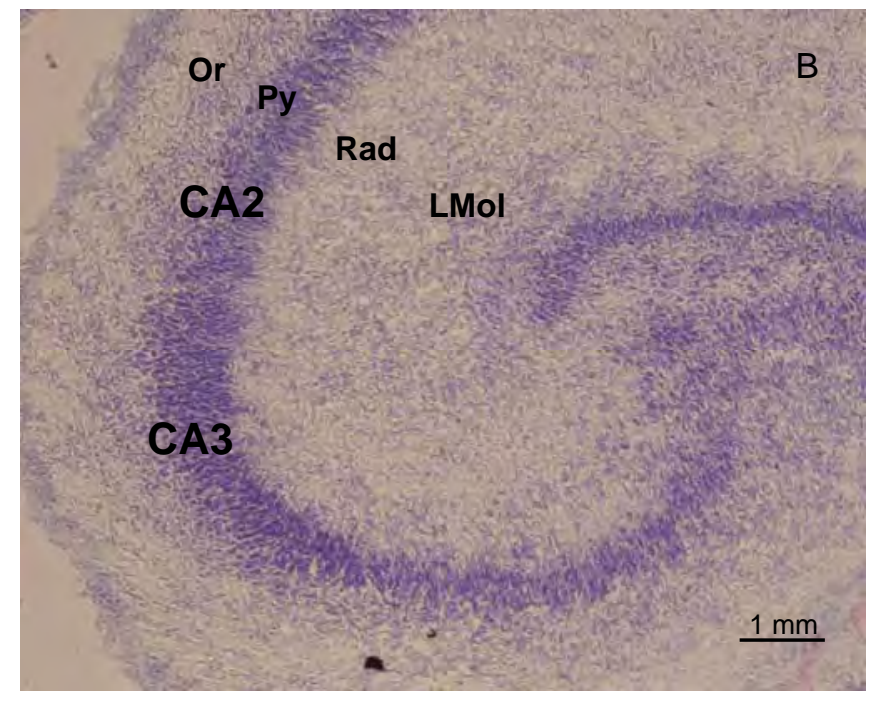

Amostra B. Região Corno de Ammon, CA3 (Corno Ammonis 3), e parte da Região Corno de Ammon, CA2 (Corno Ammonis 2), incluídas e quantificadas as seguintes camadas: camada Radiada (Ra), camada Molecular-Lacunosa (LMol). Não foram incluídas: camada Orientação (Or) e camada Piramidal (Py).Nível - 3,30 mm a partir do Bregma. Barra $1 \mathrm{~mm}$. Fonte: Camadas, modificado de Atlas PAXINOS, ASHWELL e TORK (1998).

Fonte: Allemandi, (2011).

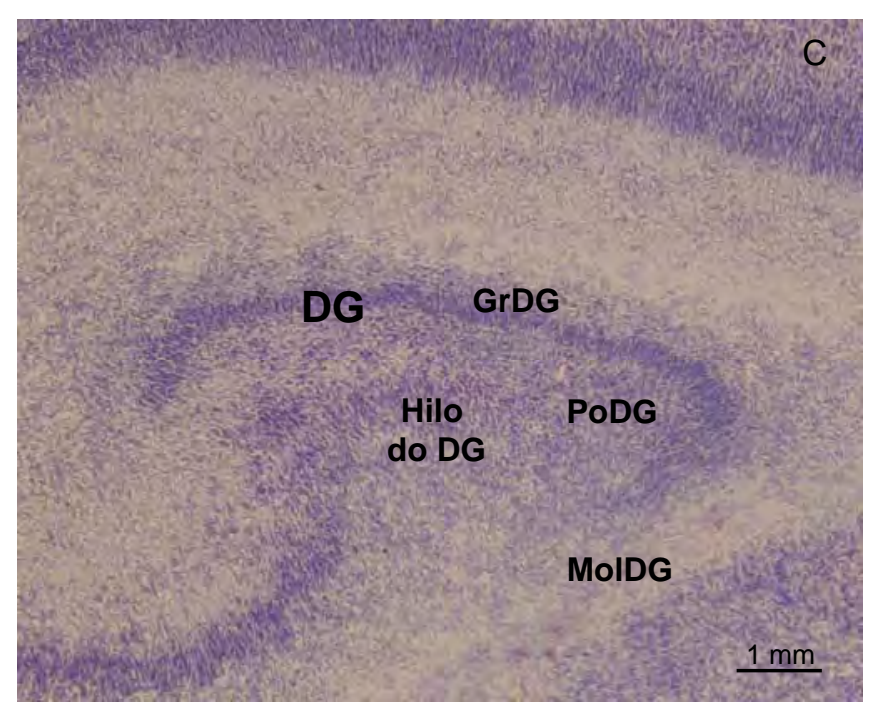

Amostra C. Região do Giro Denteado, DG (Gyrus Dentatus) incluídas e quantificadas as seguintes camadas: Hilo do Giro Denteado $(\mathrm{H})$ e Camada Polimórfica do Giro Denteado (PoDG). (não foram incluídas: a Camada Molecular do DG (MolDG) e Camada Granular do DG (GrDG). Nível - 3,30 mm a partir do Bregma. Barra $1 \mathrm{~mm}$

Fonte: Camadas, modificado de Atlas PAXINOS, ASHWELL e TORK (1998).

Fonte: Allemandi, (2011). 
3.10 Análises e Produções de Imagens

Os resultados foram analisados em microscopia de campo claro, com utilização do microscópio Nikon Eclipse E-1000. As imagens foram digitalizadas utilizando câmera digital CoolSNAP-Pro Color, acoplada a um microcomputador, com software Image Pro®Plus 6.0 (Média Cybernetics, Silver Spring, MA, EUA). Para quantificação do número de células S100ß-IR da Formação Hipocampal, os resultados foram analisados em microscopia óptica de campo claro (modelo Hund Wetzlar H-500), pelo retículo quadriculado (de $0,5 \mu \mathrm{m})$, adaptado à lente ocular.

As pranchas com fotos foram montadas utilizando os programas PhotoShop CS (Adobe). Apenas equilíbrio do brilho e contraste foi ajustado.

\subsection{Análise Estatística}

Nas análises de imunoistoquímica, os resultados foram expressos como média e desvio padrão do número de células imunorreativas. Empregamos análise de variância com dois fatores, ANOVA, e teste de Tukey, a fim de verificarmos o efeito da anóxia nas células S100ß-IR. O índice de significância adotado foi $p<0,05$.

Nas analises de Western blot, os dados foram representados como média \pm e.p.m. A análise estatística foi gerada utilizando o programa GraphPad Prism 5 (GraphPad Software Inc., CA, USA). A comparação estatística entre os grupos foi realizada usando a análise de variância de uma e de duas vias (ANOVA), seguido pelo teste de Tukey. O índice de significância considerado, $\mathrm{p} \leq 0,05$. 
4 RESULTADOS 


\subsection{Considerações Experimentais}

Os resultados utilizando imunorreatividade e Western blot, evidenciam que a anóxia neonatal promove alterações na imunorreatividade astrocitária a S100 $\beta$, tanto no NTS como nas regiões da formação hipocampal estudadas.

O dados obtidos serão apresentados nessa seção, inicialmente quanto à validação do modelo experimental utilizado e na titulação de anticorpos.. Em seguida apresentamos dados quanto à imunorreatividade de S100 $\beta$ no NTS, evidenciando que os astrócitos também estão relacionados a respostas homeostáticas reguladas por essa região. E, por fim, a quantificação da S100ßIR, por método de imunoistoquímica e Western blot, na formação hipocampal evidenciando participação significante da glia nas respostas ao estimulo empregado.

\subsection{Desenvolvimento e validação do Modelo Experimental: Anóxia neonatal}

O estudo dos efeitos da anóxia neonatal é desenvolvido em nosso laboratório por equipe multidisciplinar. Ele iniciou com a chegada de estudantes vindos da $A A C D$, onde atuavam como profissionais de fisioterapia e psicologia há considerável tempo. Estavam interessados em estudar experimentalmente o sistema nervoso nessas condições e eventuais relações com o que vivenciavam na pratica diária. Depois de concluído, que a questão deveria ser abordada com modelo animal, foi pesquisado o modelo mais adequado à nossa proposta. Foi adotado o modelo de anóxia neonatal em ratos. Para tornar curta e compreensível uma longa historia que culminou com tese de mestrado (TAKADA, 2008) e publicação na Journal of Neuroscience Methods (TAKADA et al., 2011) é anexado ao presente volume o artigo no qual colaboramos em diversas etapas.

Para validar o modelo de anóxia utilizado em nossos experimentos, quanto a privação de oxigênio e conseqüente anóxia, assim como avaliar a saturação de oxigênio periférico no sangue $\left(\mathrm{SpO}^{2}\right)$, foram utilizados e testados grupos adicionais (TAKADA et al., 2011).

Esse sistema foi avaliado: quanto ao tempo e condições de promoção de anóxia, foi definido o índice de letalidade nesse ambiente experimental (maior 
que 10\%), quanto ao tempo de permanência do animal na câmera. Foi observada, mudança comportamental motora e respiratória do animal quando exposto a ausência de oxigênio e mudança de coloração da pele, indicativos da eficiência do estimulo (STRATA et al., 2004; NAKAJIMA et al., 1999). Foi também avaliada a saturação arterial periférica de oxigênio (TREMPER e BARKER, 1989), foi utilizado oxímetro de pulso (DECKER et al., 1989).

Uma vez definidas as condições experimentais foi necessário verificar a ocorrência de alterações neurais que validassem o sistema aos propósitos do grupo e que permitissem explorações experimentais. Assim, foi efetuado o estudo da imunorreatividade de Fos em áreas respiratórias (TAKADA et al., 2011). Os resultados propiciaram o delineamento metodológico e instigaram a

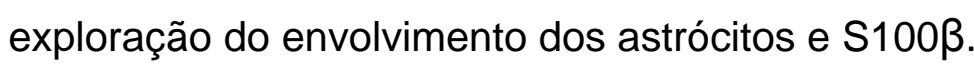

\section{3- Estudos dos Efeitos da Anóxia neonatal em Astrócitos pela S100ß-IR}

Acreditamos que a imunorreatividade da $S 100 \beta$ no NTS é um dado importante, por evidenciar ativação glial que parece ser paralela à ativação neuronal, conforme indicam dados de nosso laboratório com mapeamento no encéfalo de ratos neonatos e análise da expressão de Fos em regiões acometidas pelos efeitos tóxicos de anóxia neonatal. "Efeitos da anóxia neonatal no encéfalo de ratos: mapeamento anátomo-funcional de neurônios imunorreativos a Fos" (TAKADA, 2008).

Em ratos adultos em condição basal foi observada, em dados de nosso laboratório, distribuição de S100ß-IR no SNC "Estudo da distribuição da proteína S100ß no encéfalo de ratos" (CAMPOS, 2007), sendo as seguintes as áreas de concentração, formação hipocampal e fimbria, núcleos septais, núcleo periventricular do hipotálamo, núcleos das habênulas, núcleo paraventricular do tálamo, células ependimárias, substância cinzenta periaquedutal. Interessante marcação de $S 100 \beta$ foi observada em áreas do encéfalo relativamente próximas às cavidades por onde circula o líquor, nos ventrículos e aqueduto cerebral (CAMPOS, 2007).

O modelo modificado de anóxia neonatal (TAKADA et al., 2011), também permitiu o estudo dos efeitos da privação de oxigênio em comportamentos como memória espacial e aprendizagem, realizada em ratos 
adultos, em nosso laboratório "Avaliação comportamental de ratos submetidos à anóxia neonatal" (ITO, 2010). Dados obtidos em testes comportamentais específicos desse estudo foram observados, que ratos adultos (90/120 dias pós-natal) submetidos à anóxia neonatal apresentaram: prejuízo na capacidade de aprendizagem e navegação espacial no labirinto aquático; apresentaram menor ansiedade e atividade locomotora diminuída no teste do labirinto em cruz elevado; menor tempo em congelamento no teste de ansiedade (ITO, 2010).

O encéfalo é extremamente sensível a reduções de suprimento de oxigênio e pode lesar ou causar morte das células da formação hipocampal, uma das mais sensíveis ao estímulo anóxico e mais vulnerável do SNC, assim como o córtex cerebral e núcleos basais. Estas áreas estão envolvidas em funções cognitivas (aprendizado e memória) e funções motoras (CIRULLI, 2003; LOIDL et al., 2000; BUWALDA, 1995).

Esses dados evidenciaram alterações neurais e nos suscitou dúvidas quanto a eventuais e conseqüentes alterações na glia, o que nos induziu a propor o presente estudo. Analisar os astrócitos pelas alterações da S100ß-IR, e explorar esses dados em relação à ativação neural, isto é, a glia e os neurônios estão em ação conjunta nesse processo anóxico.

4.4 Titulação de anticorpos primários e determinação do tempo de espera pós estimulo.

A titulação foi efetuada para os anticorpos primários S100ß e GFAP em diferentes concentrações diluídas em tampão fosfato e triton- $X$, tendo sido escolhida a concentração que melhor propiciou marcação e que produziu menor background. Estas foram: S100ß 1:10000 e GFAP 1:1000, este ultimo anticorpo contudo não foi utilizado nos experimentos por ter sido decidido efetuar a avaliação quantitativa por Western blot.

Foram efetuadas análises de S100B-IR para determinar o melhor horário de perfusão do animal com solução fixadora em diferentes tempos após estimulo, quais sejam 30 minutos, 2 horas e 7 horas em P2.

Assim, S100B-IR perfundidos 30 minutos pós estimulo de anóxia apresentou alta variação individual, a 2 horas os resultados do grupo P2 na 
condição anóxia evidenciou diferença significante em relação ao animal basal, mas esta não ocorreu a 7 horas pós estímulo. Portanto, foi adotado o tempo de espera de 2 horas após estimulo nas condições sham e anóxia.

4.5 Resultados de S100ß-IR no NTS: 2 h e 7 h pós experimentos

O Núcleo do Trato Solitário (NTS) é estrutura determinante nos processos respiratórios e cardiovasculares, necessários à homeostasia e manutenção da pressão arterial, da freqüência cardíaca, bem como níveis adequados de oxigênio, $\mathrm{pH}$ e metabolitos. Essas características funcionais constituíram o motivo de escolha dessa região para avaliar a S100ß-IR e a eficácia do modelo.

A delimitação citoarquitetônica do NTS foi acompanhada por cortes histológicos corados em Nissl. As células imunorreativas a $\mathrm{S} 100 \beta$ foram facilmente identificadas pela marcação de seu citoplasma, com seu diâmetro menor que 10 micra, indicativo de astrócitos, tendo sido encontradas de forma difusa pelo núcleo em questão estudado, assim como foi notada sua presença dispersa por todo tecido adjacente. Imagens evidenciam células $S 100 \beta-I R$ no NTS, em ratos neonatos do grupo P2 nas condições mencionadas, em P2, $2 \mathrm{~h}$ há maior marcação na condição $A$ que $S$, porem esse dado não é observado em P2, 7 h (Figura 11).

Observou-se em P2 A 2 h um aumento de 20,83\% no número de células em relação ao P2 S $2 \mathrm{~h}$, sendo significante essa diferença, $p<0.05$.

P2 A $7 \mathrm{~h}$ apresentou 0,38\% células a menos que P2 S $7 \mathrm{~h}$, não sendo considerada significante essa diferença.

Não houve diferença significante entre os grupos experimentais e o Basal, $p=0.407$ e em relação às condições Sham, $p=0.06$. Tendo sido observada maior variação individual no grupo basal (desvio padrão) do que nos grupos S e A (Tabela 3, Figura 10). 
Tabela 3- Média e desvio padrão de S100ß-IR no NTS: número de células imunorreativas em ratos, grupo $\mathrm{P} 2,2 \mathrm{~h}$ e $7 \mathrm{~h}$ pós experimentos, nas condições Basal (B), Sham (S) e Anóxia (A).

\begin{tabular}{lcr}
\hline & 2 horas & 7 horas \\
\hline Basal & & \\
Sham & $21,1 \pm 1.4$ & $26,1 \pm 1.4$ \\
Anóxia & $25.5 \pm 0.8^{\star}$ & $26.0 \pm 1.7$ \\
\hline${ }^{*}$ P2 A 2 h vs P2 S 2 h, ANOVA, $p<0.05$. Para todos os grupos $n=4$.
\end{tabular}

Figura 10- Gráfico da média e desvio padrão de células S100ß-IR no NTS, do grupo P2, 2 h e P2 7 h

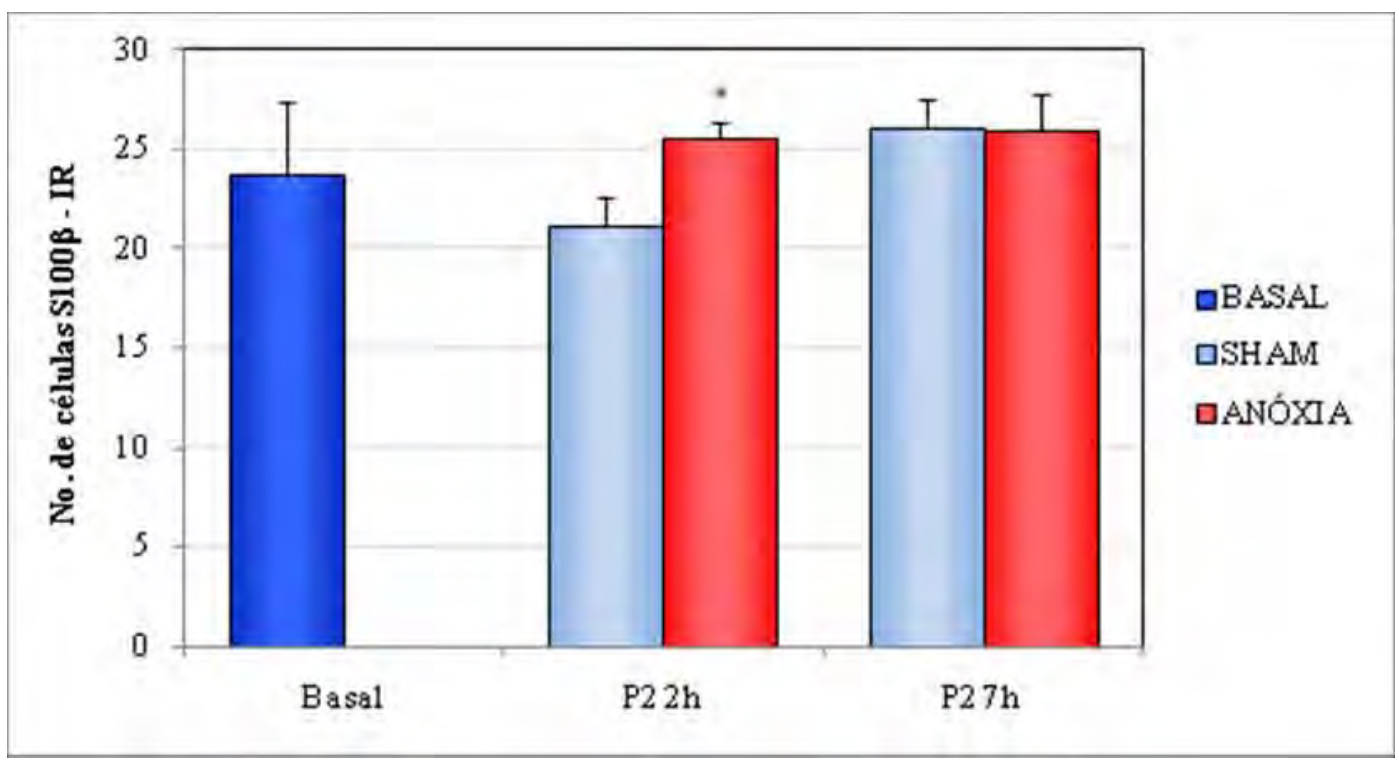

Numero de células imunorreativas, nas condições: Basal (B), Sham (S) e Anóxia (A). *P2 A 2 h vs P2 S 2 h, ANOVA, p<0.05. Para todos os grupos $n=4$.

Fonte: Allemandi, (2011). 
Figura 11- S100ß-IR no Núcleo Trato Solitário, grupo P2 2 h e P2 7 h
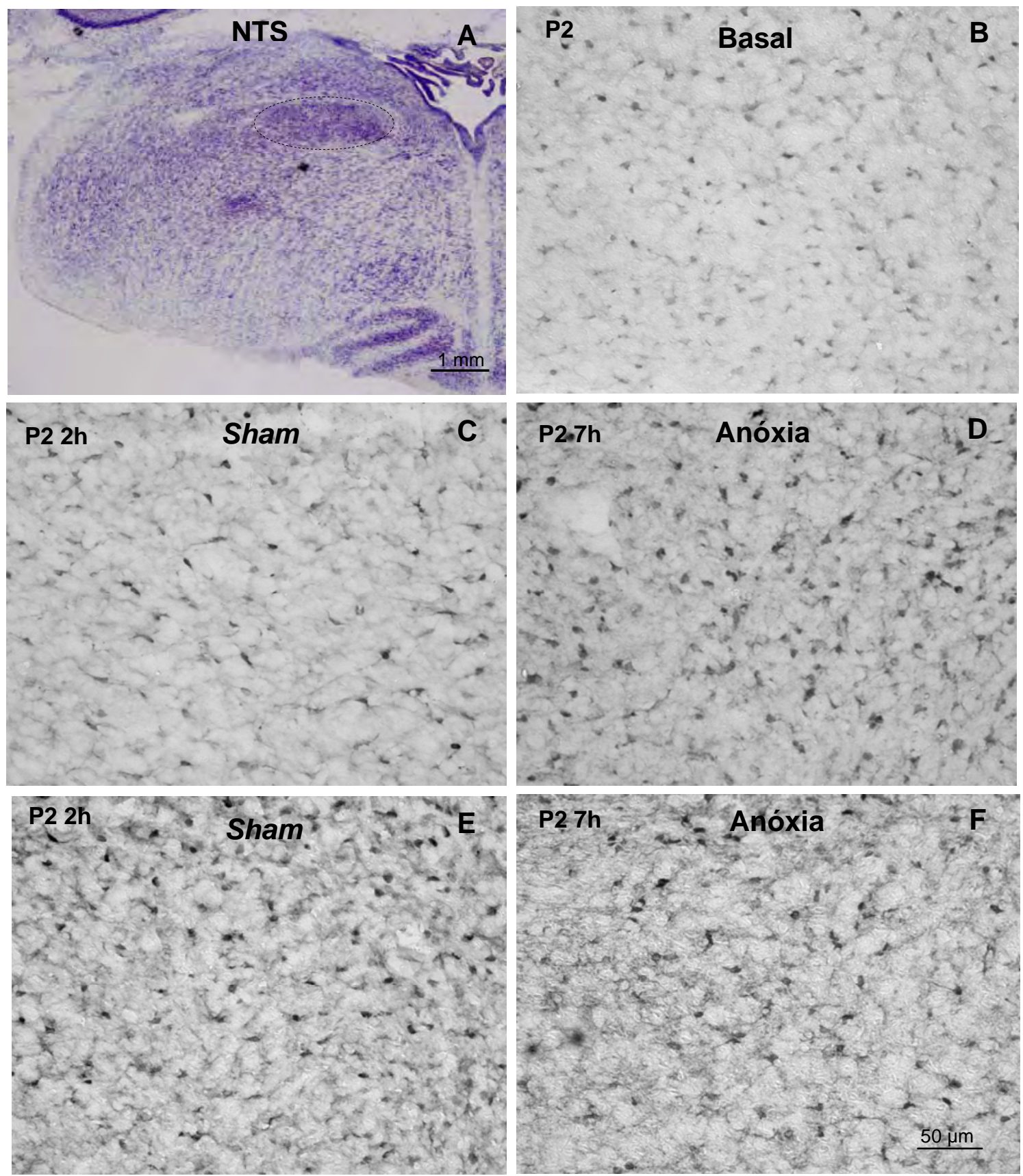

Cortes semi-seriados para detecção de células imunorreativas. Em A, coloração por Nissl, linha seccionada indica localização do núcleo estudado. Barra $1 \mathrm{~mm}$. Em B, condição Basal; em C e E, condição Sham; em D e F, condição Anóxia. Em C e D, P2 2h. Em E e F, P2 7h. Barra $50 \mu \mathrm{m}$ (B,C,D,E,F). Nível - 3,30 mm a partir do Bregma.

Fonte: Allemandi, (2011). 
4.6 Identificação do fenótipo da glia - dupla marcação de S100ß-IR e GFAP-IR

Além das características morfológicas, os astrócitos têm sido identificados mais recentemente pela expressão de uma proteína que Ihes é exclusiva, a chamada proteína ácida fibrilar glial (GFAP), sendo considerada proteína constituinte em filamentos intermediário e freqüentemente utilizado para sua identificação, tornou-se ferramenta útil para a identificação das células imunopositivas e sua regionalização pela colocalização com S100ß.

Uma correta e eficaz realização da técnica imunoistoquímica e imunofluorescência foram imprescindíveis, para determinação de marcação com intensidade suficiente, que não deixasse dúvidas relativas à presença ou ausência do antígeno no tecido. Assim sendo, após efetuarmos a titulação dos anticorpos, isto é, testarmos diferentes diluições dos anticorpos, realizamos análise em células imunorreativas de $\mathrm{S} 100 \beta$ e GFAP em ratos nos grupos, $\mathrm{P} 2$ e P7, nas condições: Basal, Sham e Anóxia ( $n=1)$.

Podemos observar imagens, de células imunorreativas reagidas em técnica de imunofluorescência na região CA3 da formação hipocampal, no grupo $P 2$ condição $A$, e no grupo $P 2$ condição $B$, o mesmo ocorre no grupo P7 A e no grupo P7 B (Figuras 13 e 14).

Células imunopositivas a $S 100 \beta$ são observadas com emissão em luz vermelha, pelo uso do anticorpo secundário marcado com CY3 (imagens: $A, D, G$ ); células imunopositivas a GFAP são observadas marcadas com emissão em luz verde, com o uso do anticorpo secundário marcado com FITC (imagens: B,E,H), e células marcadas com emissão de luz em amarelo indicam a colocalização de S100ß e GFAP pelo uso do filtro FITC/TRITC (imagens: C, $F, I)$.

Os animais da condição basal (imagens: $A, B, C$ ), encontram-se com baixa marcação para ambos os anticorpos; os cortes imunopositivos da condição sham (imagens: $D, E, F$ ), apresentam marcação aparentemente maior que a condição basal; e os cortes da condição anóxia (imagens: G,H,I), evidenciam acentuada marcação em relação às condições anteriores para cada um dos anticorpos e mesmo de colocalização. 
A colocalização encontrada de $S 100 \beta$ com GFAP confirmam a natureza da célula da glia assim como o estágio de desenvolvimento, já que durante o amadurecimento da célula, GFAP, se torna presente na vida extra-uterina.

Assim, explorar a imunopositividade em astrócitos reforça seu papel nessas regiões ora estudadas, tornando importante a verificação de sua ativação em paralelo com a ativação neural, como observamos no NTS com S100 $\beta$ e Fos (TAKADA, 2008). Nossos resultados demonstram, confirmam e complementam muitas observações ultra-estruturais anteriormente descritas e que poderiam estar demonstrando a ação nociva, no caso a anóxia, ainda não descrita, sobre a glia e a subseqüente reação dos astrócitos conforme demonstrado pela imunorreatividade da $\mathrm{S} 100 \beta$, em colocalização e possível reatividade com GFAP. 
Figura 13- Imunofluorescência de $S 100 \beta$ vs GFAP, no grupo P2, região CA3 da Formação Hipocampal
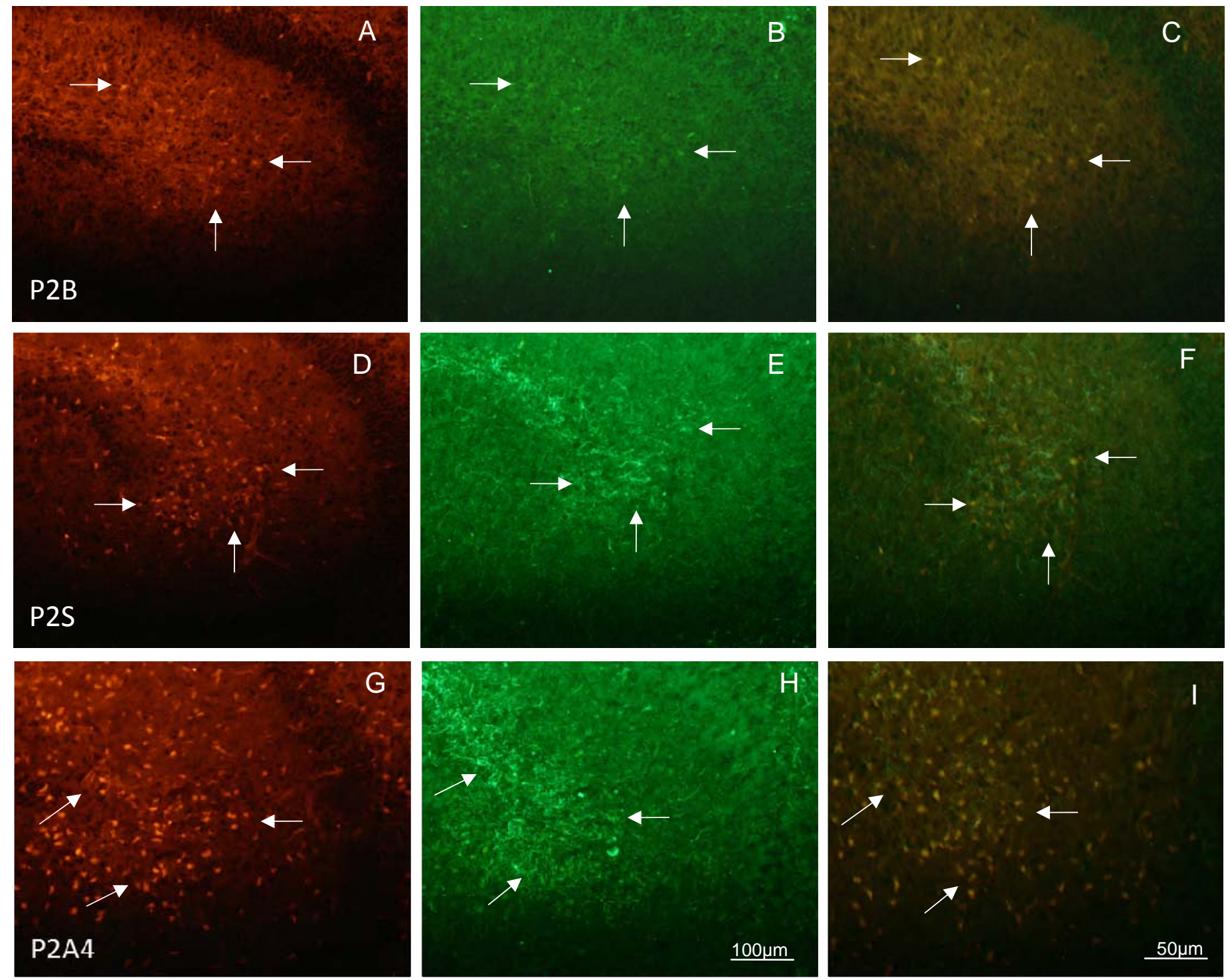

Colocalização de cortes semi-seriados, para detecção de células imunorreativas na região CA3+CA2: $(A, D, G), S 100 \beta$ (CY3, vermelho); (B,E,H), GFAP (FITC, verde); (C,F,I), dupla marcação S100ß vs GFAP. (A,B,C), P2B; (D,E,F), P2S;

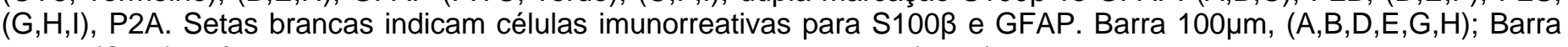
$50 \mu \mathrm{m},(\mathrm{C}, \mathrm{F}, \mathrm{I})$. Nível - 3,30mm a partir do Bregma. Fonte: Allemandi, (2011). 
Figura 14- Imunofluorescência de $S 100 \beta$ vs GFAP, grupo P7, região CA3 da Formação Hipocampal
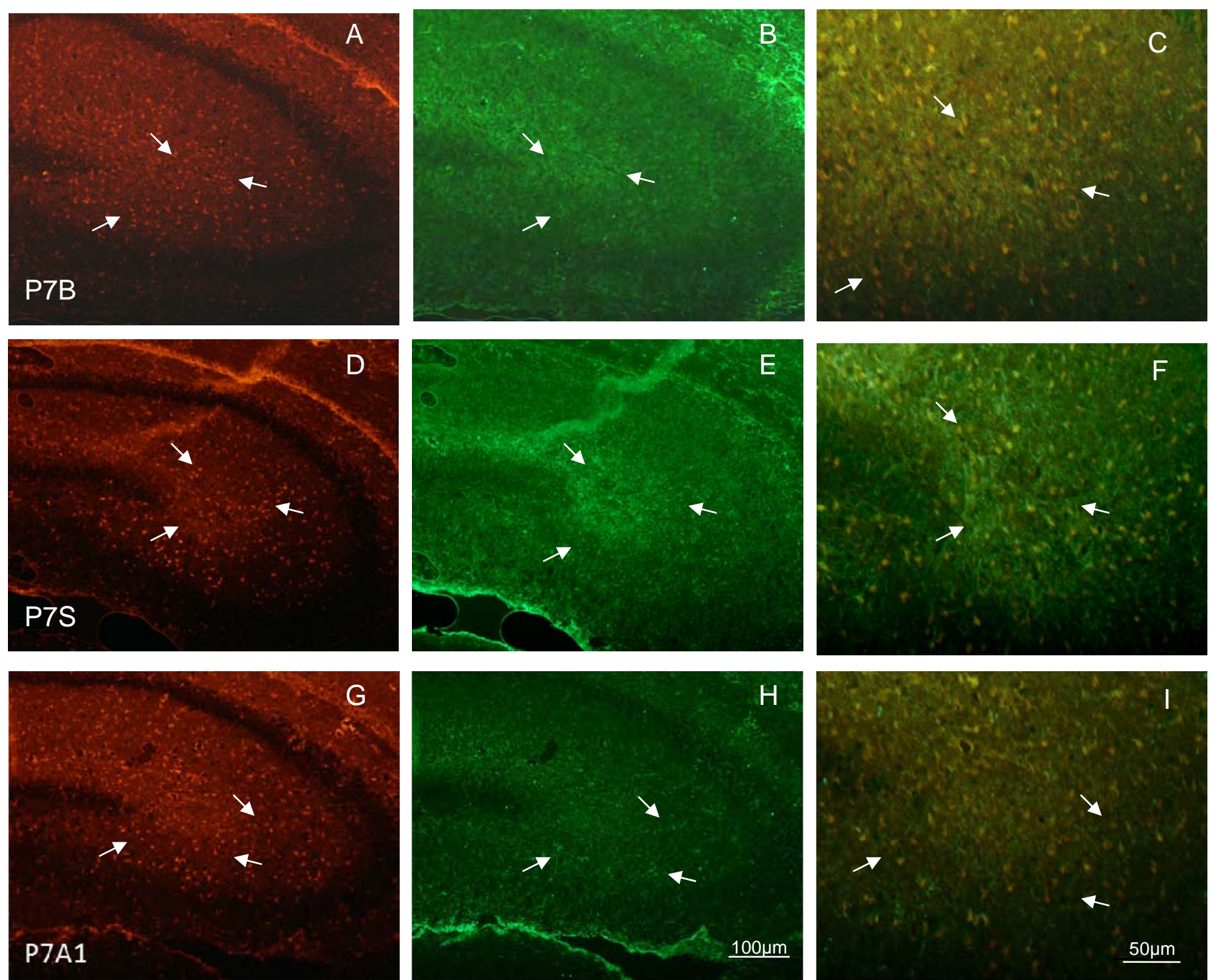

Colocalização de cortes semi-seriados, para detecção de células imunorreativas na região CA3+CA3: $(A, D, G), S 100 \beta$ (CY3, vermelho); (B,E,H), GFAP (FITC, verde); (C,F,I), dupla marcação S100ß vs GFAP. (A,B,C), P7B; (D,E,F), P7S; $(\mathrm{G}, \mathrm{H}, \mathrm{I}), \mathrm{P} 7 \mathrm{~A}$. Setas brancas indicam células imunorreativas para S100ß e GFAP. Barra $100 \mu \mathrm{m},(\mathrm{A}, \mathrm{B}, \mathrm{D}, \mathrm{E}, \mathrm{G}, \mathrm{H})$; Barra $50 \mu \mathrm{m},(\mathrm{C}, \mathrm{F}, \mathrm{I})$. Nível - 3,30 mm a partir do Bregma. Fonte: Allemandi, (2011). 
Acreditamos que este modelo é adequado à exploração de alguns aspectos neurais relacionados às seqüelas motoras, cognitivas $e$ comportamentais decorrentes da anóxia neonatal.

Após estes estudos qualitativos, através de observação microscópica, optamos analisar regiões da formação hipocampal, por ser uma das áreas mais susceptíveis à morte neuronal após privação de oxigênio.

\subsection{Resultados de S100ß-IR, na Formação Hipocampal}

A sensibilidade da formação hipocampal à falta de $\mathrm{O}^{2}$ ocasiona danos e podem desencadear subseqüentes respostas diferenciadas, temporal e topograficamente localizadas. Local com aguda resposta irá mediar reparo no tecido (GIULIAN, et al., 1993) a qual é seguido por eventos neurodegenerativos e neuroprotetivos após danos teciduais (CUNHA et al., 2007).

Encontramos diferença significativa na imunorreatividade de $\mathrm{S} 100 \beta$ do grupo P2 condição $A$, em relação às demais condições (P2B e P2S) do mesmo grupo, e, mesmo em relação ao grupo P7 na condição Basal, em relação às demais condições (P7S e P7A) do mesmo grupo, das regiões estudadas (CA1, CA3+CA2, DG) da formação hipocampal.

\subsubsection{Análise Quantitativa para S100ß-IR na Formação Hipocampal em CA1, grupos $P 2$ e $P 7$, condições: $B, S$ e $A$}

\section{= grupo P2 vs P7:}

Podemos observar em P7 B 156,3\% a mais no número de células S100ß-IR, em relação a P2 B, sendo significante essa diferença, $p<0.05$.

P7 A apresentou diminuição de 48,8\% no número de células S100ß-IR em relação a P2 A, sendo significante essa diferença, $p<0.05$.

P7 S apresentou 40,9\% a mais no número de células em relação a P2 S, mas não foi considerada significante essa diferença.

\section{= grupo P2:}

Observou-se em P2 A um aumento 40,5\% e 96,4\% no número de células S100ß-IR, em relação às condições P2 B e P2 S respectivamente, sendo significante essa diferença, $p<0.05$. 
P2 S apresentou $28,4 \%$ a menos no número de células S100ß-IR em relação a P2 B, mas não foi considerada significante essa diferença.

\section{= grupo P7:}

P7 A e P7 S apresentaram 71,9\% e 60,6\%, respectivamente, a menos no número de células $S 100 \beta-I R$, em relação a $P 7 B$, sendo significante essa diferença, $\mathrm{p}<0.05$.

P7 A apresentou $28,7 \%$ a menos no número de células S100ß-IR em relação a P7 S, mas não foi considerada significante essa diferença.

Os resultados assim representados: tabela (4), figuras (15, 17 e 18).

Tabela 4- Média e desvio padrão do número de células S100ß-IR em CA1 na Formação Hipocampal em ratos do grupo P2 e P7, nas condições: Basal (B), Sham (S) e Anóxia (A)

\begin{tabular}{lcc}
\hline & $\mathrm{P} 2$ & $\mathrm{P} 7$ \\
\hline Basal & $115,0 \pm 13,0$ & $294,7 \pm 43,2$ * \\
Sham & $82,3 \pm 7,5$ & $116,0 \pm 8,2{ }^{\#}$ \\
Anóxia & $161,6 \pm 19,0{ }^{\# \$}$ & $82,7 \pm 8,0$ *\# \\
\hline *P2 vs P7, ${ }^{\#}$ vs. Basal, ${ }^{\$}$ vs. Sham, ANOVA, $p<0.05$. Para todos os grupos $n=3$
\end{tabular}

Figura 15 - Gráfico da média e desvio padrão de células S100ß-IR em CA1, na Formação Hipocampal

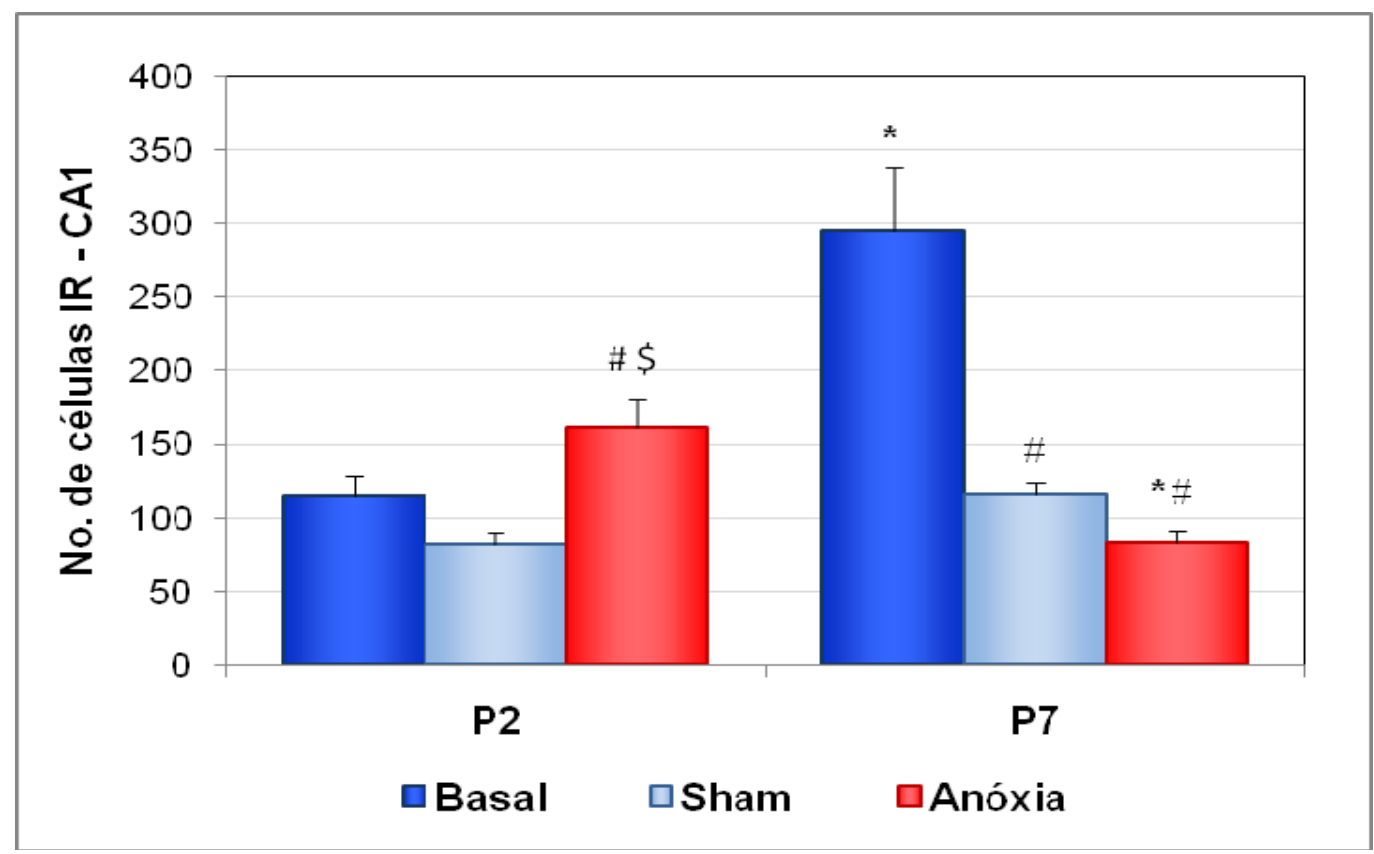

Em ratos P2 e P7, nas condições: Basal (B), Sham (S) e Anóxia (A). *P2 vs. P7, " vs. Basal, ${ }^{\$}$ vs. Sham, ANOVA, $p<0.05$. Para todos os grupos $n=3$.

Fonte: Allemandi (2011). 
Figura 16- Fotomicrografias em campo claro de S100ß-IR ilustram a organização das camadas na região CA1 da Formação Hipocampal
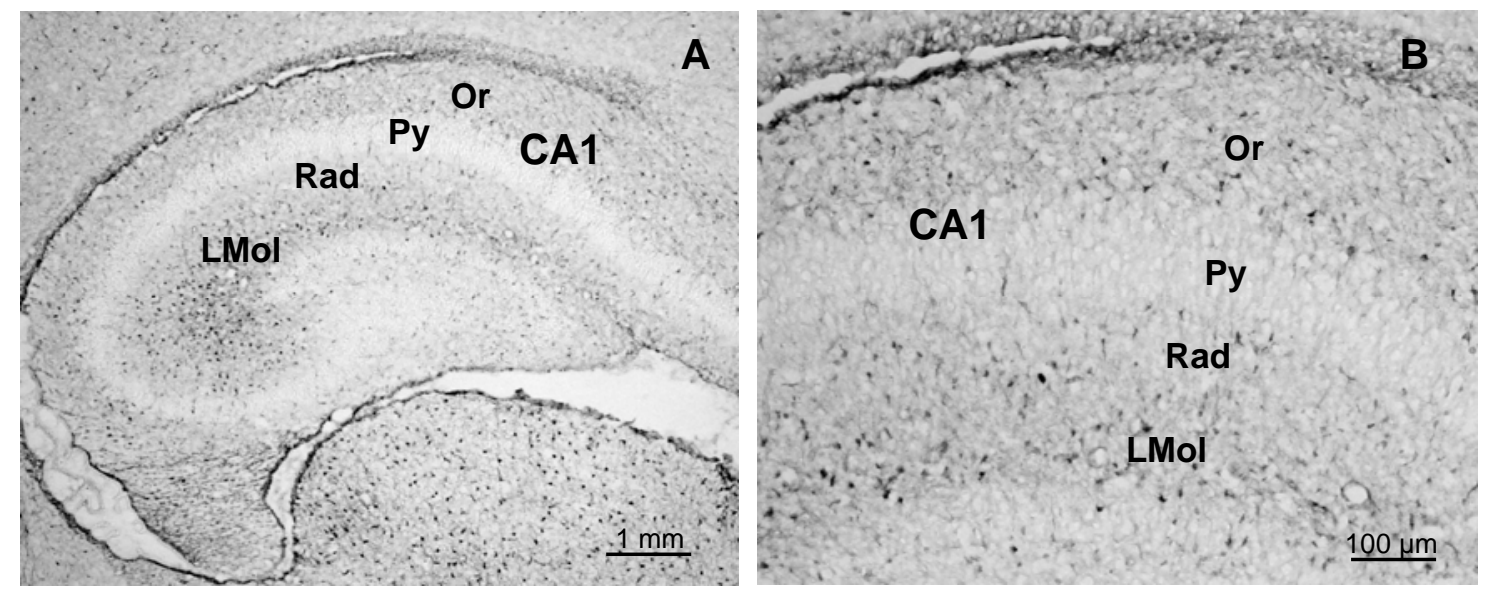

(A), camadas na região CA1; (B), só camada quantificada. Barras: $1 \mathrm{~mm}$ e $100 \mu \mathrm{m}$, respectivamente. Nível $-3,30 \mathrm{~mm}$ a partir do Bregma.

Fonte: Allemandi (2011). 
Figura 17- Fotomicrografias em campo claro de cortes imunorreativos para detecção de S100ß em CA1, na Formação Hipocampal, grupo P2

Basal

(B)

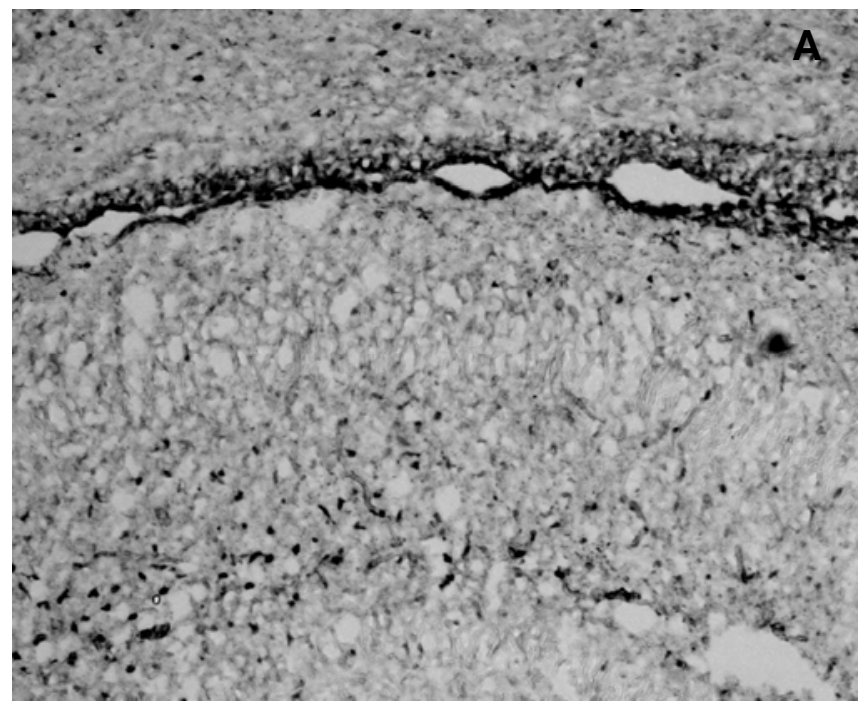

(S)

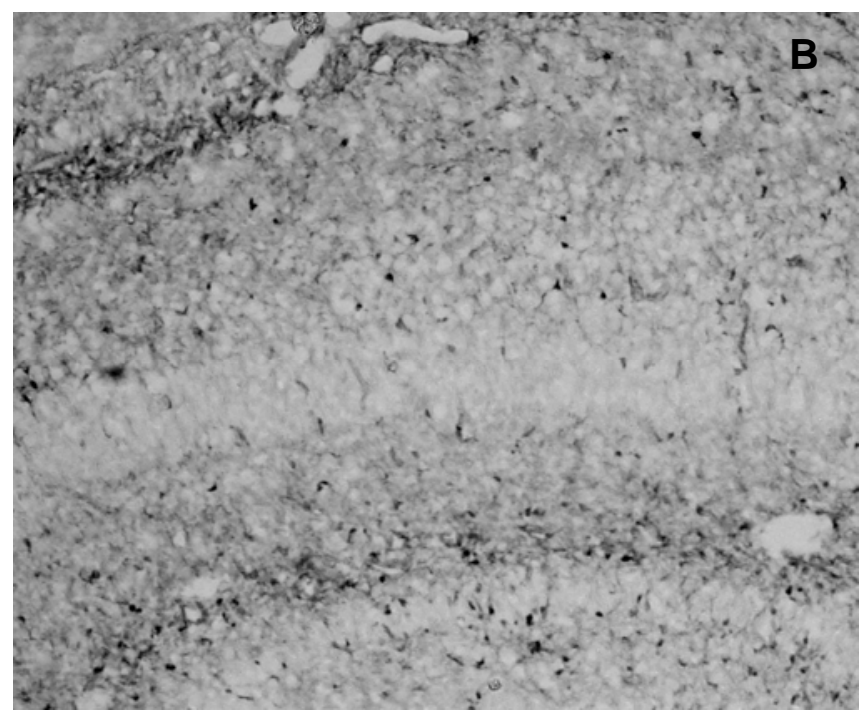

Anóxia

(A)

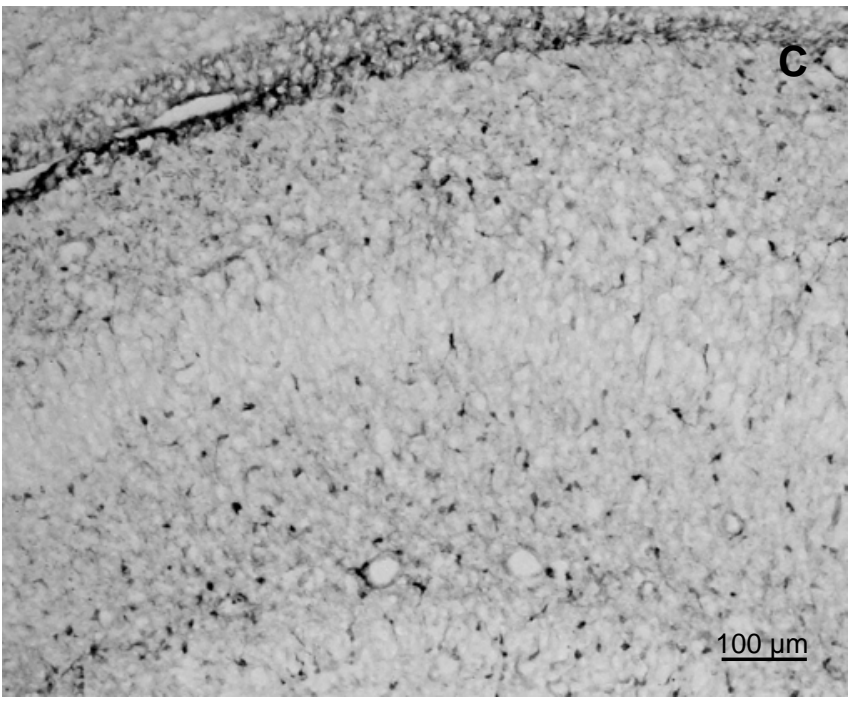

Em (A), Basal; (B), Sham; (C), Anóxia. Barra $100 \mu \mathrm{m}$, para todas as imagens. Nível - 3,30 mm a partir do Bregma.

Fonte: Allemandi, (2011). 
Figura 18- Fotomicrografias em campo claro de cortes imunorreativos para detecção de S100ß em CA1, na Formação Hipocampal, grupo P7

Basal

(B)

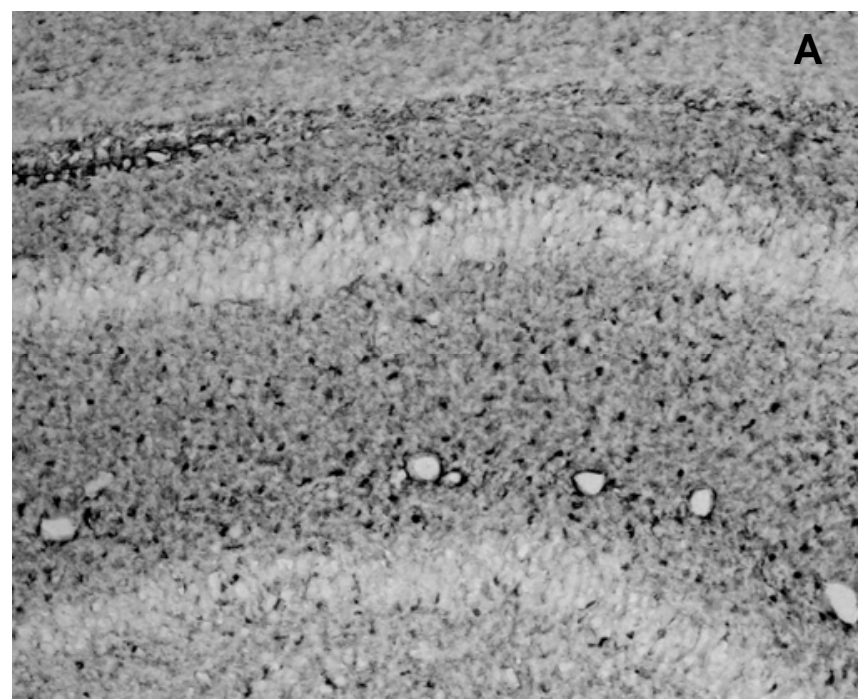

Sham

(S)

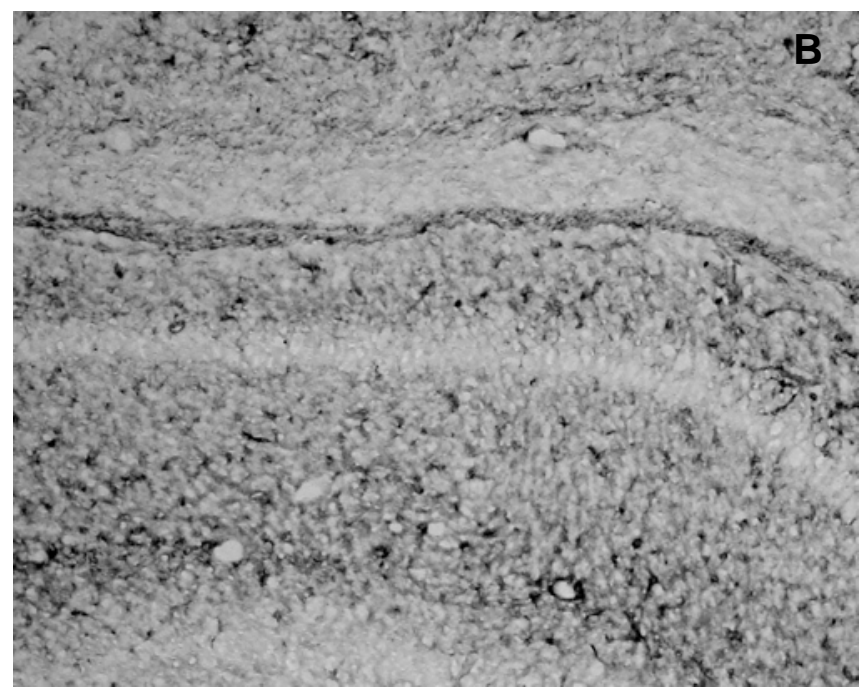

Anóxia

(A)

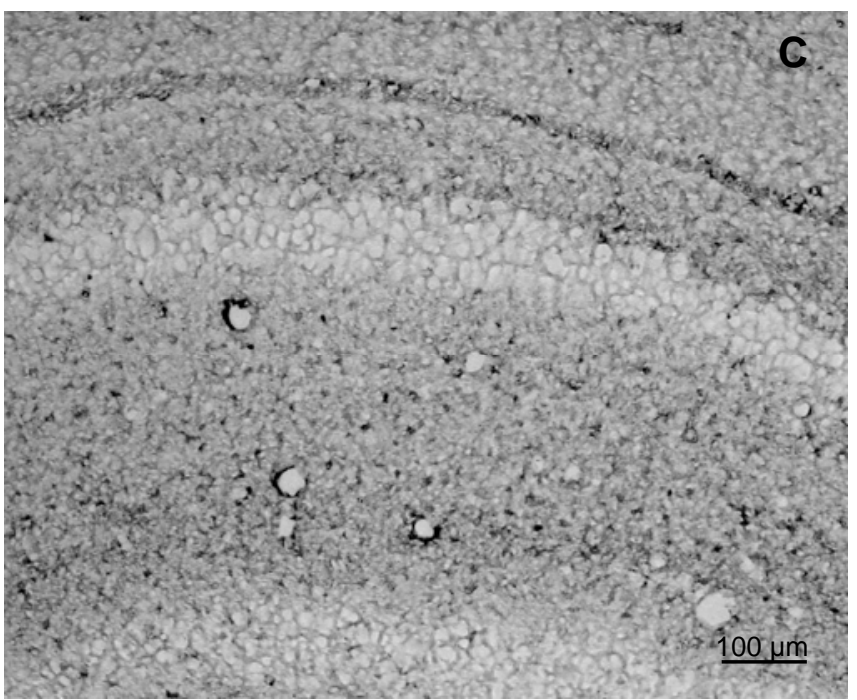

Em (A), Basal; (B), Sham; (C), Anóxia. Barra $100 \mu \mathrm{m}$, para todas as imagens. Nível - 3,30 mm a partir do Bregma.

Fonte: Allemandi, (2011). 
4.7.2 Análise Quantitativa para S100ß-IR na Formação Hipocampal em $C A 3+C A 2$, grupos $P 2$ e $P 7$, condições: $B, S$ e $A$

\section{= grupo P2 vs P7:}

Podemos observar em P7 B 31.4\% a mais no número de células S100ßIR, em relação a P2 B, mas não foi considerada significante essa diferença.

P7 A apresentou diminuição de 29.4\% no número de células S100ß-IR em relação a P2 A, sendo significante essa diferença, $p<0.05$.

P7 S apresentou $146.0 \%$ a mais no número de células em relação a P2 $\mathrm{S}$, sendo significante essa diferença, $\mathrm{p}<0.05$.

\section{= grupo P2:}

Observou-se em P2 A um aumento 178.9\% no número de células S100ß-IR, em relação a P2 S, sendo significante essa diferença, $p<0.05$.

P2 A apresentou $20.0 \%$ de aumento no número de células S100ß-IR em relação a P2 B, mas não foi considerada significante essa diferença.

P2 S apresentou 57.0\% a menos no número de células S100ß-IR em relação a P2 B, sendo significante essa diferença, $p<0.05$.

\section{= grupo $\mathbf{P 7}$ :}

P7 A apresentou 35.6\%, a menos no número de células S100ß-IR, em relação a $\mathrm{P} 7 \mathrm{~B}$, sendo significante essa diferença, $\mathrm{p}<0.05$.

P7 A apresentou 20.0\% a menos no número de células S100ß-IR em relação a P7 S, mas não foi considerada significante essa diferença.

P7 S apresentou 19.5\% a menos no número de células S100ß-IR em relação a P7 B, mas não foi considerada significante essa diferença.

Os resultados assim representados: tabela (5), figuras (19, 21 e 22). 
Tabela 5- Média e desvio padrão do número de células S100ß-IR em CA3+CA2 na Formação Hipocampal, em ratos do grupo P2 e P7, nas condições: Basal (B), Sham (S) e Anóxia (A)

\begin{tabular}{lcc}
\hline & \multicolumn{1}{c}{$\mathrm{P} 2$} & $\mathrm{P} 7$ \\
\hline Basal & $244,7 \pm 3,5$ & $321,7 \pm 30,5$ \\
Sham & $105,3 \pm 30,4^{\#}$ & $259,0 \pm 15,5 *$ \\
Anóxia & $293,7 \pm 33,0^{\$}$ & $207,3 \pm 12,1$ *\# \\
\hline${ }^{*}$ P2 vs P7, ${ }^{\star}$ vs. Basal, ${ }^{\$}$ vs. Sham, ANOVA, $p<0.05$. Para todos os grupos $n=3$
\end{tabular}

Figura 19 - Gráfico da média e desvio padrão de células S100ß-IR em CA3+CA2, na Formação Hipocampal em ratos P2 e P7

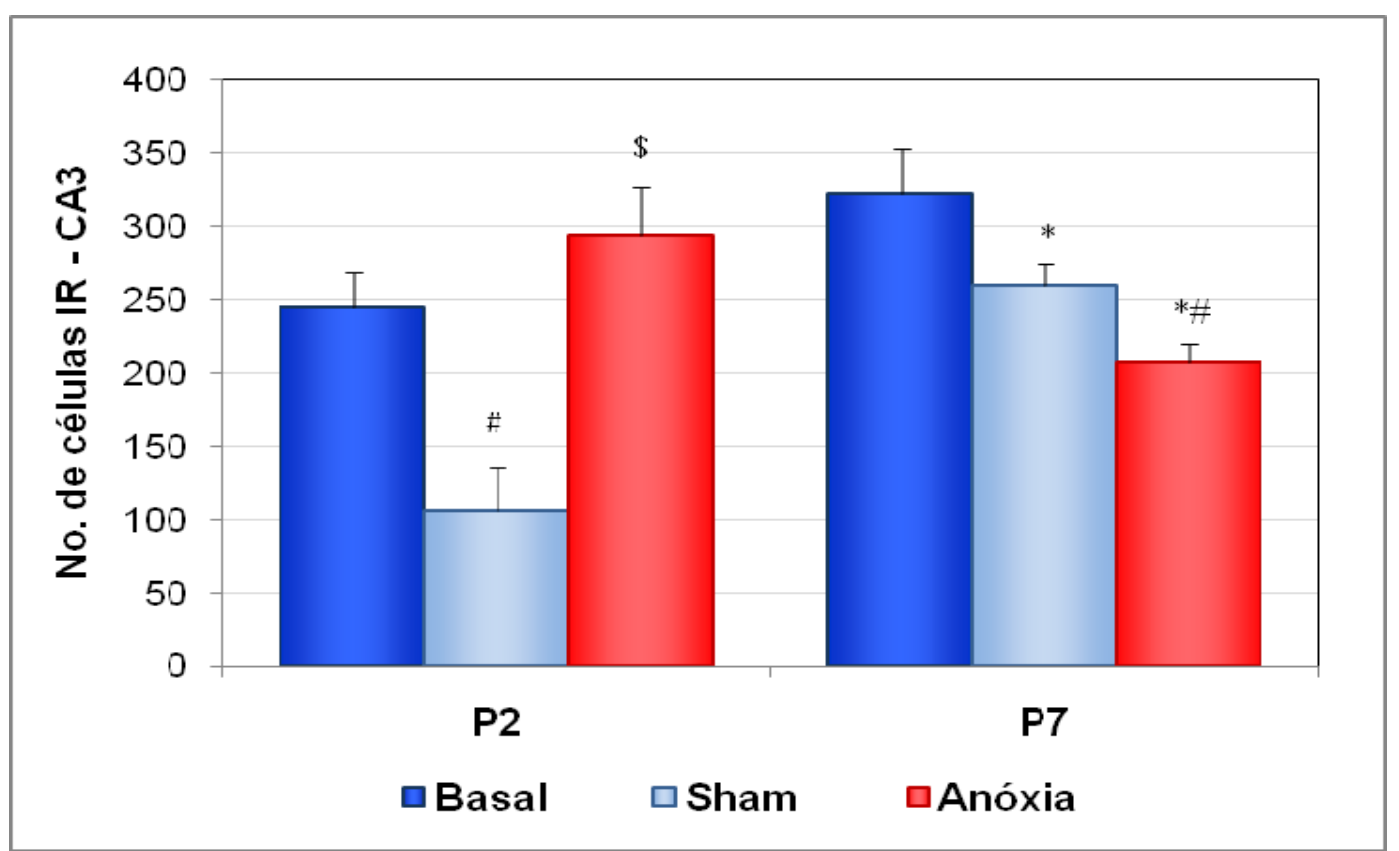

nas condições: Basal (B), Sham (S) e Anóxia (A). *P2 vs. P7, ${ }^{\#}$ vs. Basal, ${ }^{\$}$ vs. Sham, ANOVA, p $<0.05$. Para todos os grupos $n=3$.

Fonte: Allemandi (2011).

Figura 20 - Fotomicrografias em campo claro de S100ß-IR, ilustram a organização das camadas na região CA3+CA2, da Formação Hipocampal
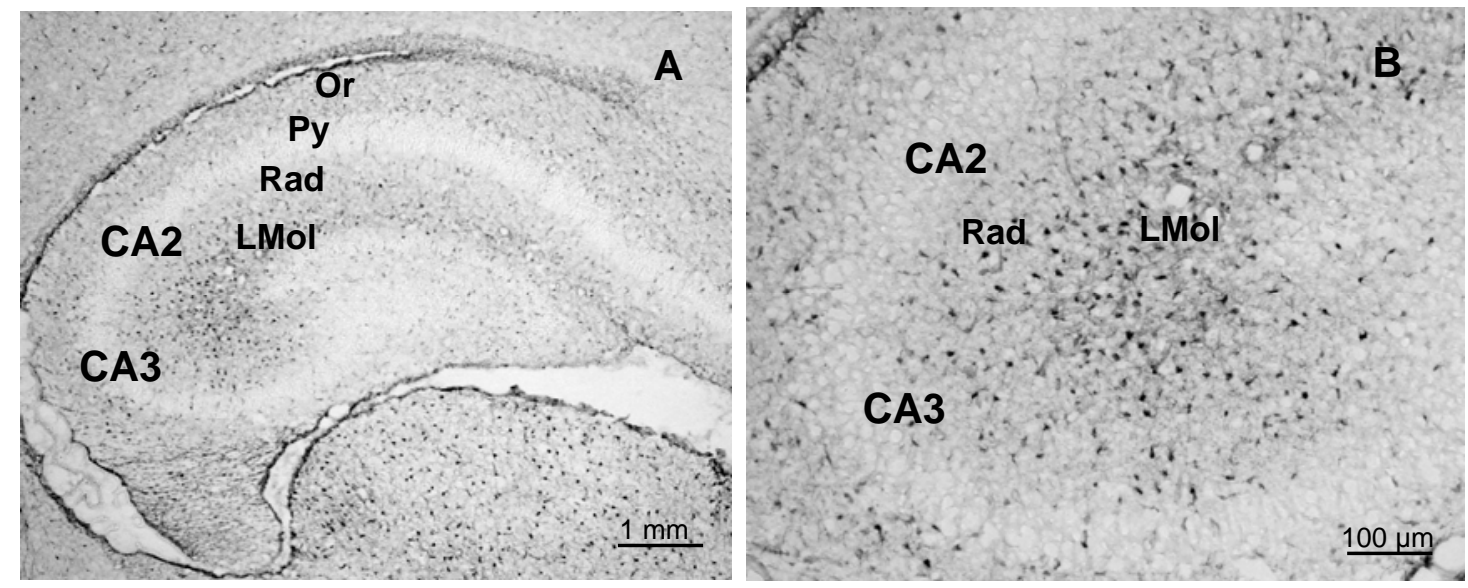

(A), camadas na região CA3+CA2; (B), somente camadas quantificadas. Barras: $1 \mathrm{~mm}$ e $100 \mu \mathrm{m}$, respectivamente. Nível $-3,30 \mathrm{~mm}$ a partir do Bregma.

Fonte: Allemandi, (2011). 
Figura 21- Fotomicrografias em campo claro de cortes imunorreativos para detecção de S100ß-IR em CA3+CA2, na Formação Hipocampal, grupo P2

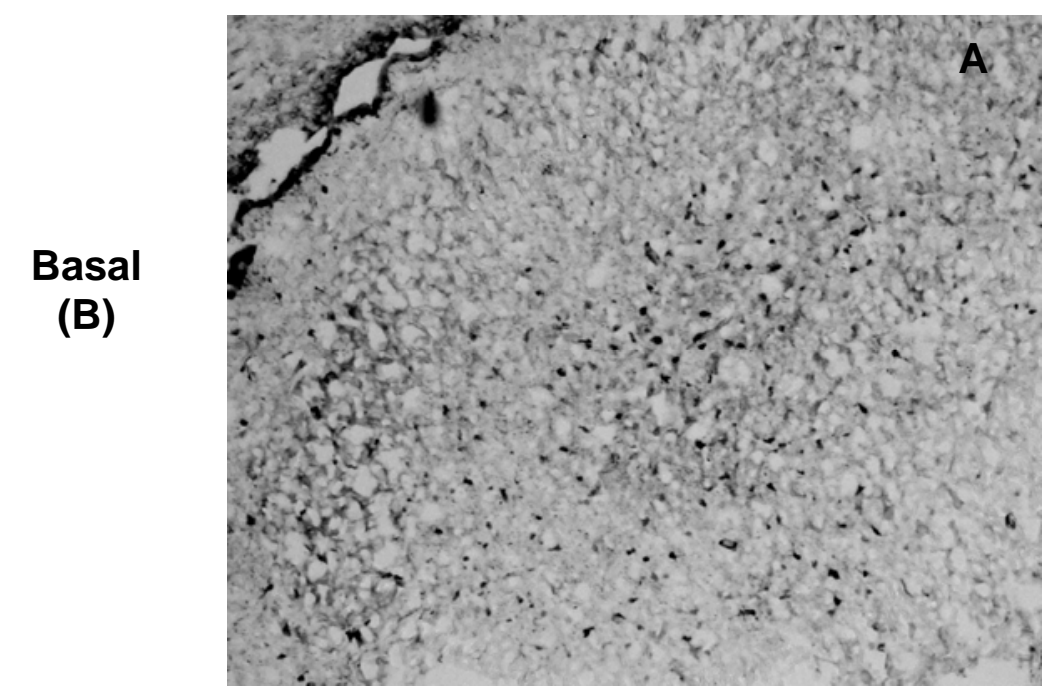

Sham

(S)

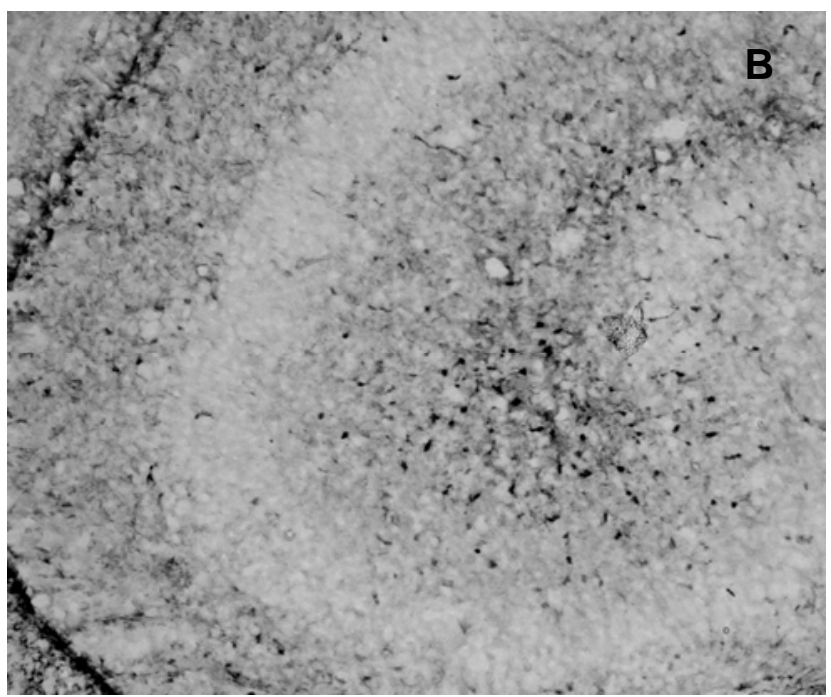

Anóxia

(A)

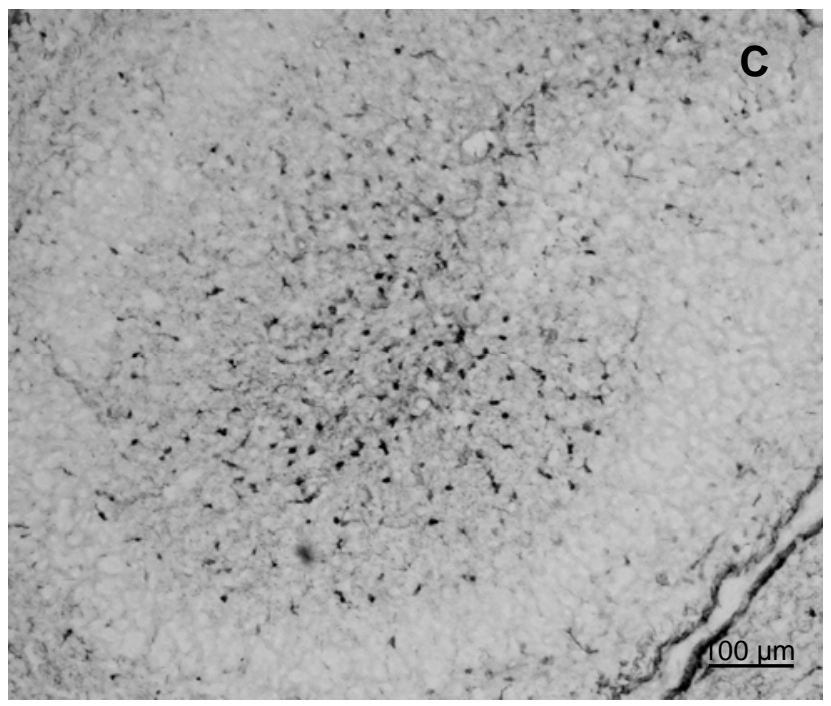

Em (A), Basal; (B), Sham; (C), Anóxia. Barra $100 \mu \mathrm{m}$, para todas as imagens. Nível - 3,30 mm a partir do Bregma.

Fonte: Allemandi, (2011). 
Figura 22- Fotomicrografias em campo claro de cortes imunorreativos para detecção de S100ß em CA3+CA2, na Formação Hipocampal, grupo P7

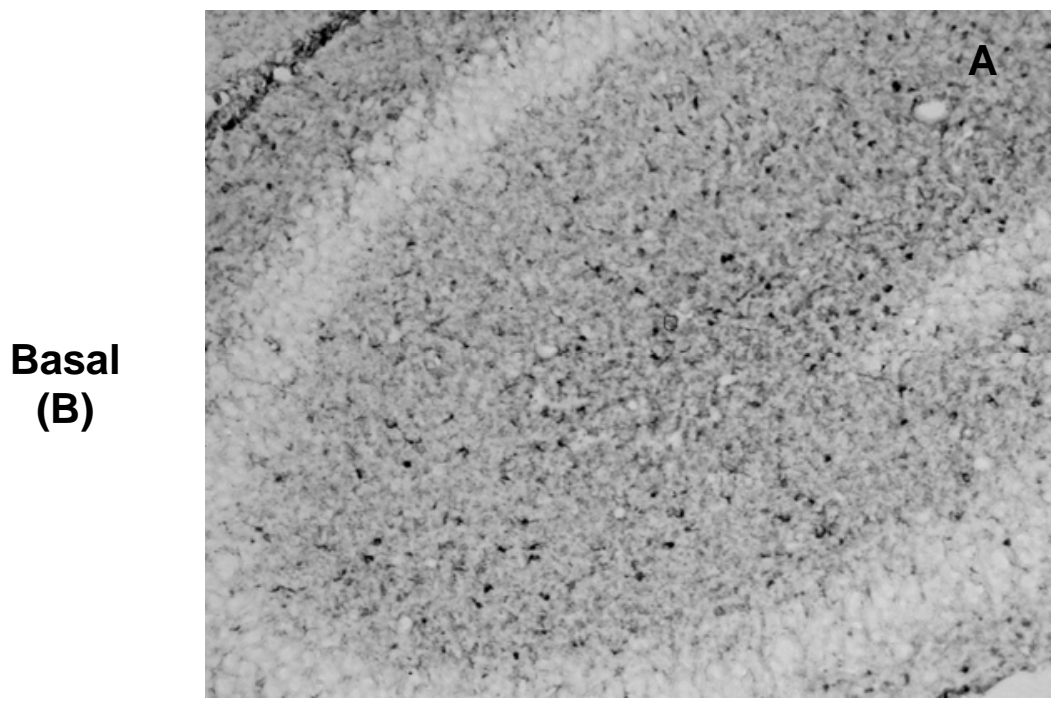

Sham

(S)

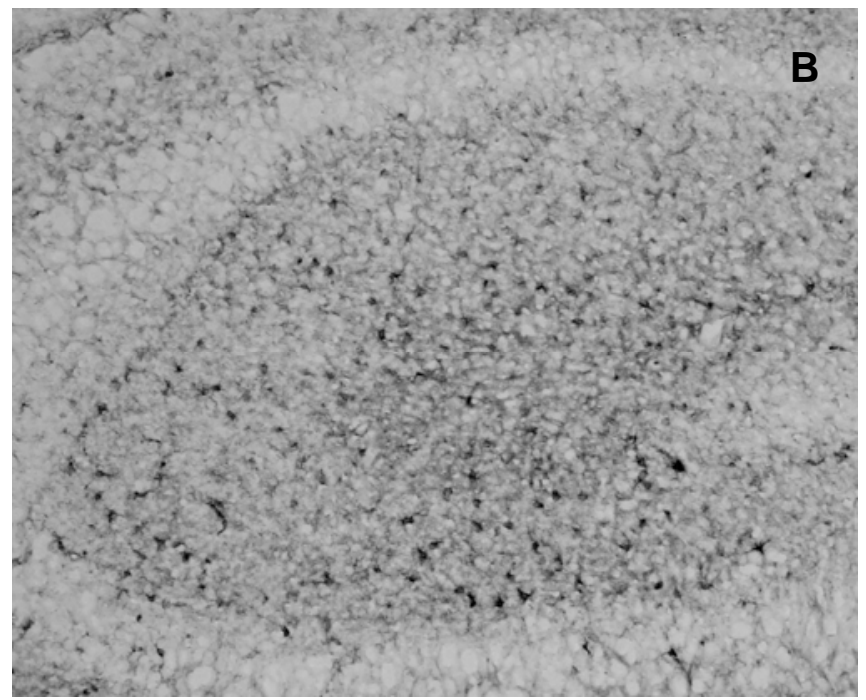

Anóxia

(A)

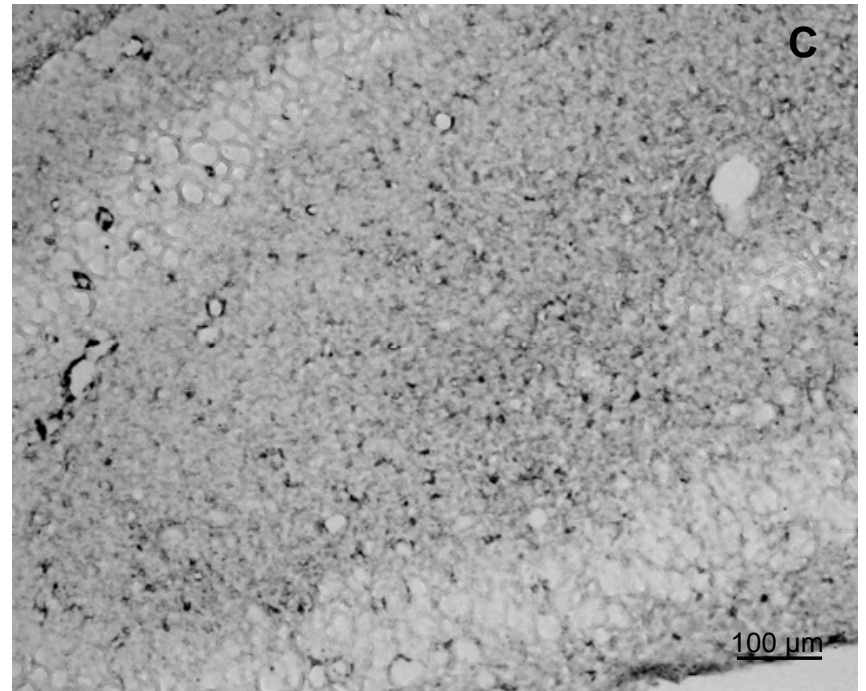

Em (A), Basal; (B), Sham; (C), Anóxia. Barra $100 \mu \mathrm{m}$, para todas as imagens. Nível - 3,30 mm a partir do Bregma.

Fonte: Allemandi, (2011). 
4.7.3 Análise Quantitativa para S100ß-IR na Formação Hipocampal em DG, grupos $P 2$ e $P 7$, condições: $B, S$ e $A$

\section{= grupo P2 vs P7:}

Podemos observar em P7 B 199.4\% a mais no número de células S100ß-IR, em relação a P2 B, sendo significante essa diferença, $p<0.05$.

P7 A apresentou diminuição de 54.6\% no número de células S100ß-IR em relação a P2 A, sendo significante essa diferença, $p<0.05$.

P7 S apresentou $192.6 \%$ a mais no número de células em relação a P2 $\mathrm{S}$, sendo significante essa diferença, $\mathrm{p}<0.05$.

\section{= grupo P2:}

Observou-se em P2 A um aumento $154.0 \%$ e $223.2 \%$ no número de células S100ß-IR, em relação às condições P2 B e P2 S respectivamente, sendo significante essa diferença, $p<0.05$.

P2 S apresentou 21.4\% a menos no número de células S100ß-IR em relação ao P2 B, mas não foi considerada significante essa diferença.

\section{= grupo P7:}

P7 A apresentou 61.5\% e 49.8\%, a menos no número de células S100ß$\mathrm{IR}$, em relação a $\mathrm{P} 7 \mathrm{~B}$ e $\mathrm{P} 7 \mathrm{~S}$ respectivamente, sendo significante essa diferença, $p<0.05$.

P7 S apresentou 23.2\% a menos no número de células S100ß-IR em relação a $\mathrm{P} 7 \mathrm{~B}$, foi significante essa diferença, $\mathrm{p}<0.05$.

Os resultados assim representados: tabela (6), figuras (23, 25 e 26).

Tabela 6- Média e desvio padrão do número de células S100ß-IR em DG na Formação Hipocampal, em ratos do grupo P2 e P7, nas condições: Basal (B), Sham (S) e Anóxia (A)

\begin{tabular}{lcc}
\hline & $\mathrm{P} 2$ & $\mathrm{P} 7$ \\
\hline Basal & $50,0 \pm 7,5$ & $149,6 \pm 7,8^{*}$ \\
Sham & $39,3 \pm 5,0$ & $115,0 \pm 11,5^{\star *}$ \\
Anóxia & $127,0 \pm 16,1{ }^{\# \$}$ & $57,7 \pm 5,5 * \$ \$$ \\
\hline$\bullet \quad$ P2 vs P7, ${ }^{\#}$ vs. Basal, ${ }^{\$}$ vs. Sham, ANOVA, $p<0.05$. Para todos os grupos $n=3$
\end{tabular}


Figura 23 - Gráfico da média e desvio padrão de células S100ß-IR em DG, na Formação Hipocampal em ratos P2 e P7

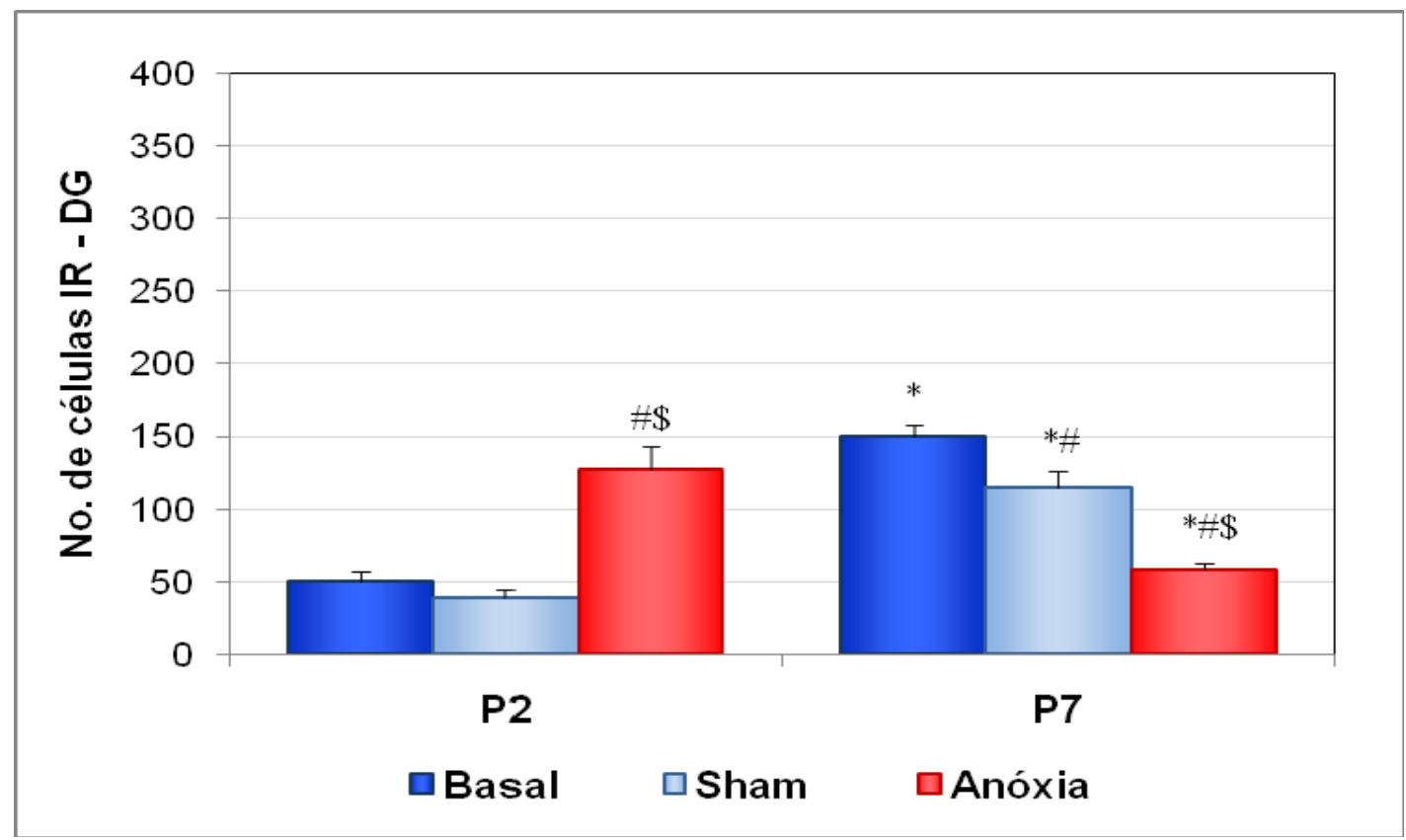

nas condições: Basal (B), Sham (S) e Anóxia (A). *P2 vs. P7, ${ }^{*}$ vs. Basal, ${ }^{\$}$ vs. Sham, ANOVA, $p<0.05$. Para todos os grupos $n=3$.

Fonte: Allemandi, (2011).

Figura 24 - Fotomicrografias em campo claro de S100ß-IR ilustram a organização das camadas na região DG, da Formação Hipocampal
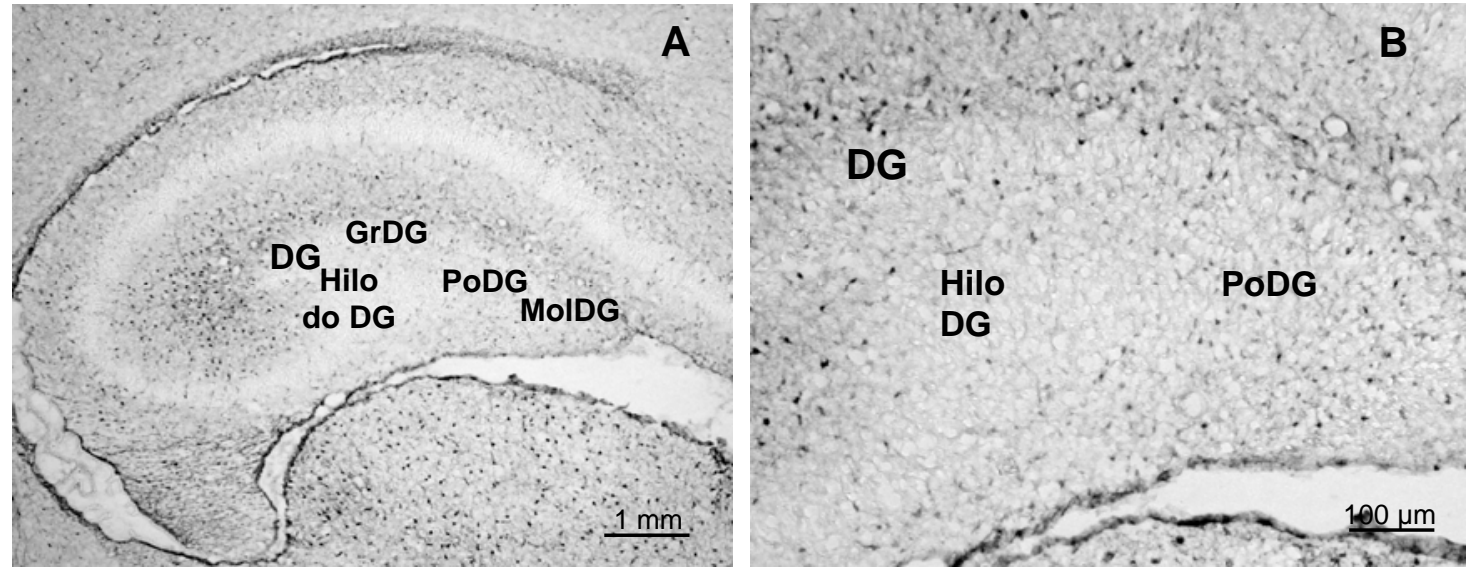

(A), camadas na região DG; (B), camadas quantificadas. Barras: $1 \mathrm{~mm}$ e $100 \mu \mathrm{m}$, respectivamente. Nível $-3,30 \mathrm{~mm}$ a partir do Bregma.

Fonte: Allemandi, (2011). 
Figura 25- Fotomicrografias em campo claro de cortes imunorreativos para detecção de S100ß em DG, na Formação Hipocampal, grupo P2

Basal

(B)

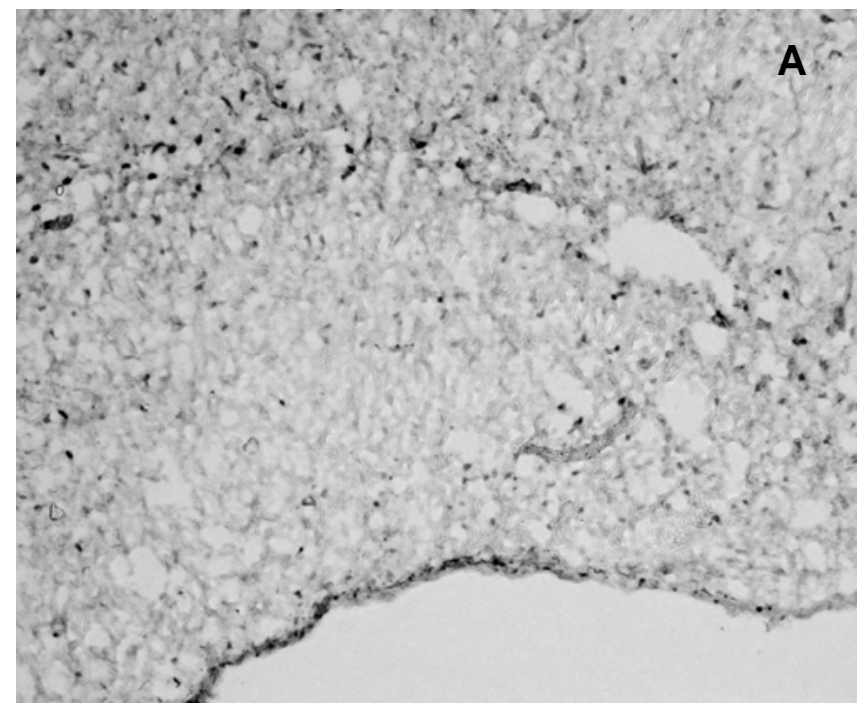

Sham

(S)

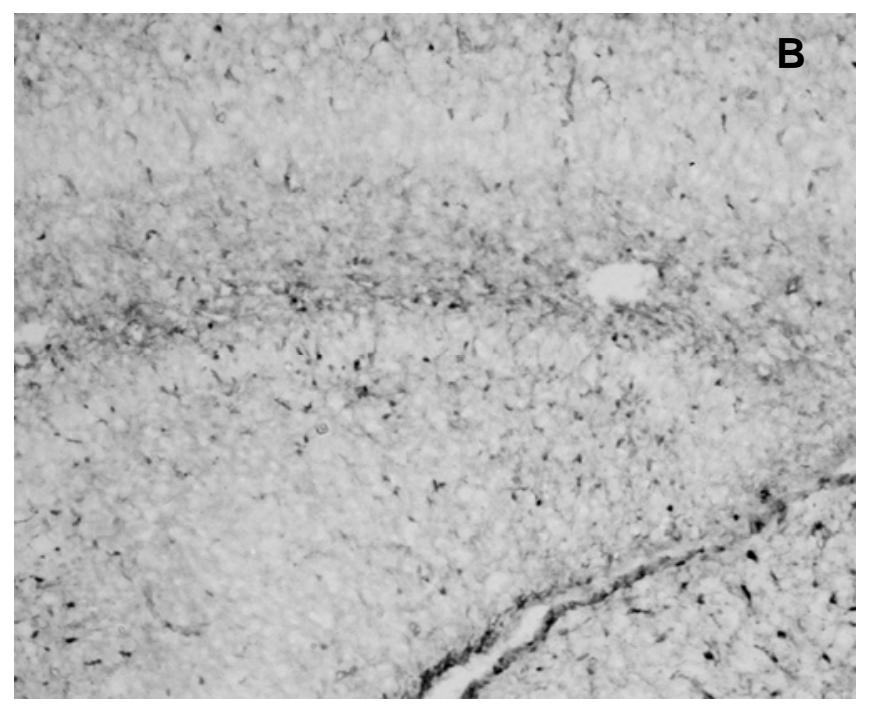

Anóxia

(A)

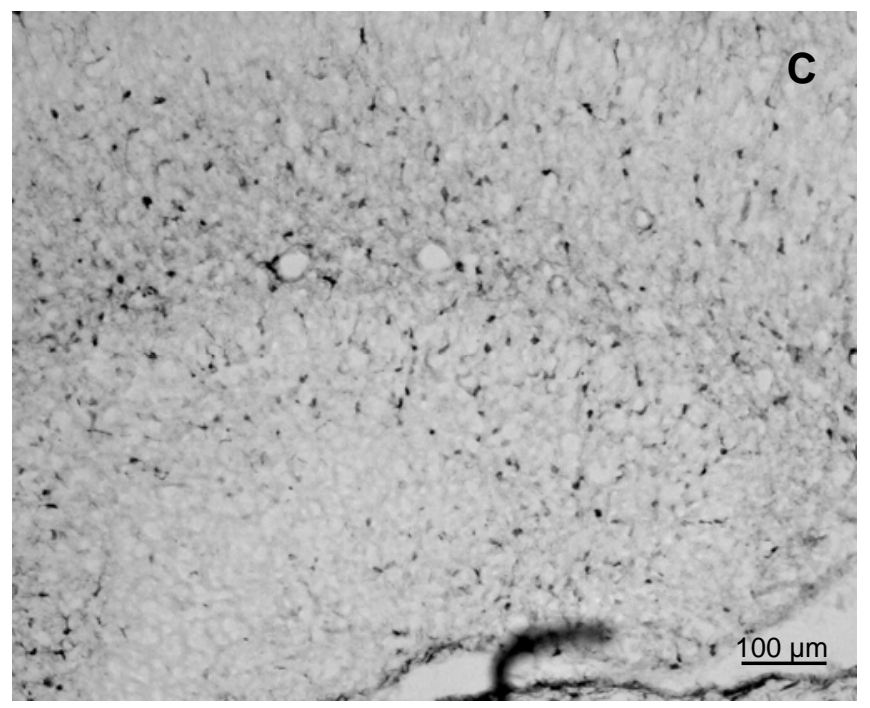

Em (A), Basal; (B), Sham; (C), Anóxia. Barra $100 \mu \mathrm{m}$, para todas as imagens. Nível - 3,30 mm a partir do Bregma.

Fonte: Allemandi, (2011). 
Figura 26 - Fotomicrografias em campo claro de cortes imunorreativos para detecção de S100ß em DG, na Formação Hipocampal, grupo P7

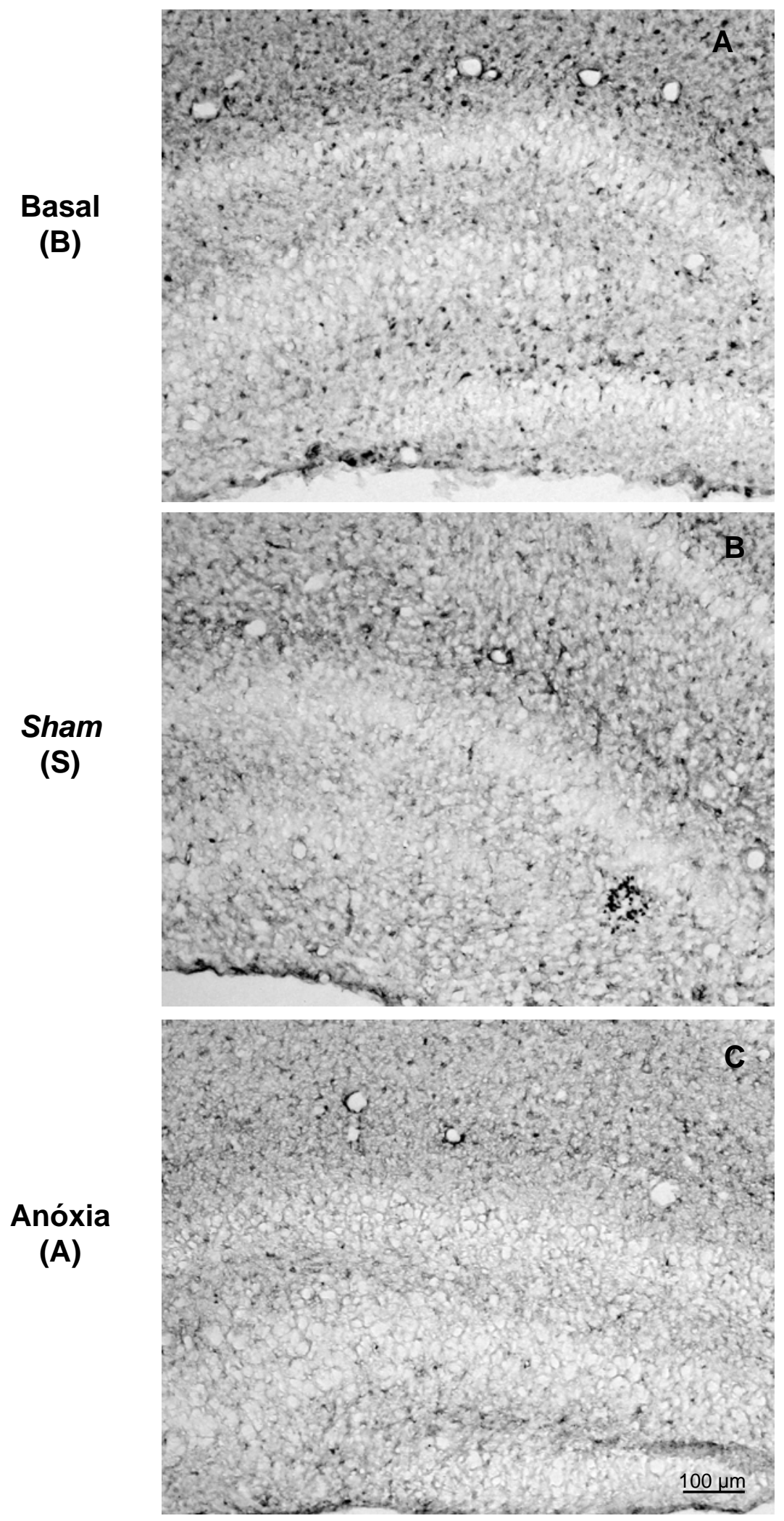

Em (A), Basal; (B), Sham; (C), Anóxia. Barra $100 \mu \mathrm{m}$, para todas as imagens. Nível - 3,30 mm a partir do Bregma.

Fonte: Allemandi, (2011). 
4.8 Análise Quantitativa de S100ß-IR, Formação Hipocampal por Western blot

Encontramos diferença significativa na densidade óptica de S100 $\beta$ na Formação Hipocampal, da condição $A$ em relação à condição $B$, independente do grupo P2 ou P7, p<0.05. A densidade média para a condição Basal foi sempre considerada 100\%, independente do grupo P2 ou P7. A $\beta$-actina foi utilizada como controle da reação e não foi observado alterações entre os grupos e condições analisadas. Os resultados estão representados em tabela e figuras nas diferentes condições, com suas respectivas bandas.

\subsubsection{Análise por Western blot para S100ß-IR na Formação Hipocampal, grupo P2, condições: $B, S$ e $A$}

Podemos observar a densidade óptica das bandas marcadas para S100ß, na Formação Hipocampal, que P2 A apresentou 40,3\% a mais em comparação às bandas de $P 2 B$, sendo significante essa diferença, $p<0.05$. $O$ grupo P2 S apresentou 26,2\% a mais em comparação às bandas de P2 B, mas não foi considerada significante essa diferença. O grupo P2 A apresentou $14,1 \%$ a mais em comparação às bandas de P2 S, mas não foi considerada significante essa diferença (Figura 27, Tabela 7). 
Figura 27- Efeito das variações na quantificação de S100ß-IR, por Western blot, na Formação Hipocampal do grupo P2

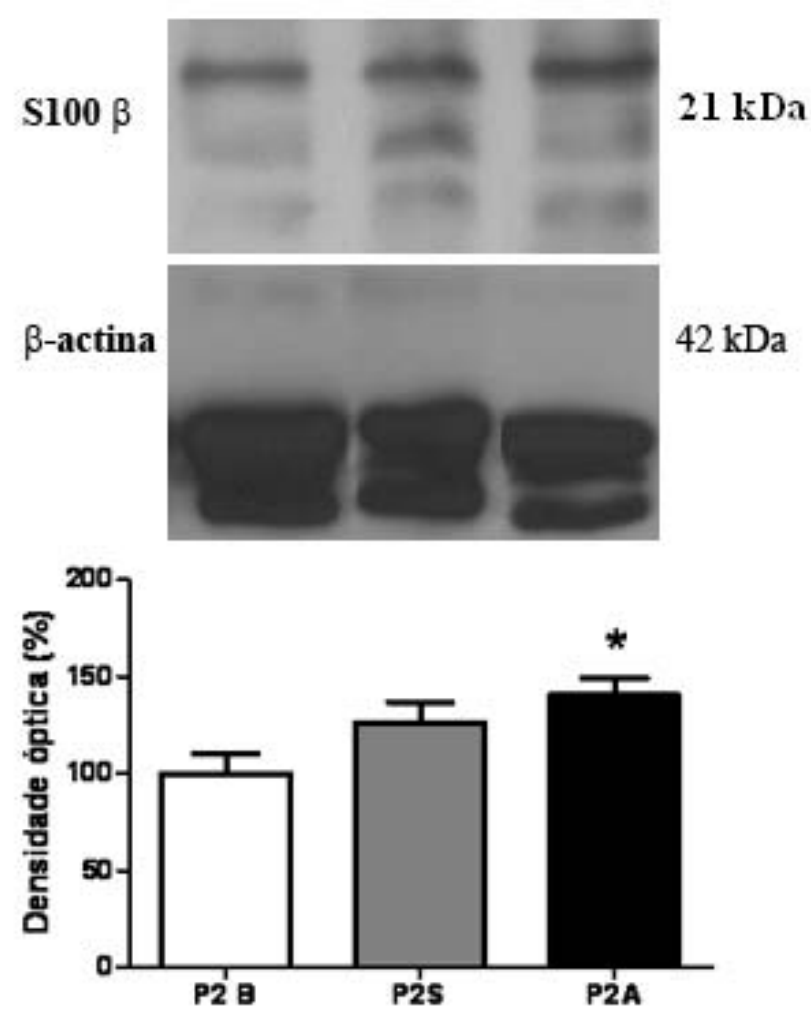

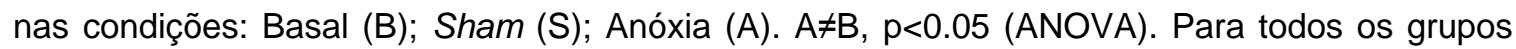
$n=8$.

Fonte: Allemandi, (2011).

4.8.2 Análise por Western blot para S100ß-IR na Formação Hipocampal, grupo P7, condições: $B, S$ e $A$

Podemos observar a densidade óptica das bandas marcadas para S100ß, na Formação Hipocampal, que P7 A apresentou 54.9\% a mais em comparação às bandas de $\mathrm{P} 7 \mathrm{~B}$, sendo significante essa diferença, $\mathrm{p}<0.05$. $\mathrm{O}$ grupo P7S apresentou 33.3\% a mais em comparação às bandas de $\mathrm{P} 7 \mathrm{~B}$, mas não foi considerada significante essa diferença. O grupo P7 A apresentou $21.6 \%$ a mais em comparação às bandas de P7S, mas não foi considerada significante essa diferença (Figura 28, Tabela 7). 
Figura 28 - Efeito das variações na quantificação de S100ß-IR por Western blot, na Formação Hipocampal do grupo P7
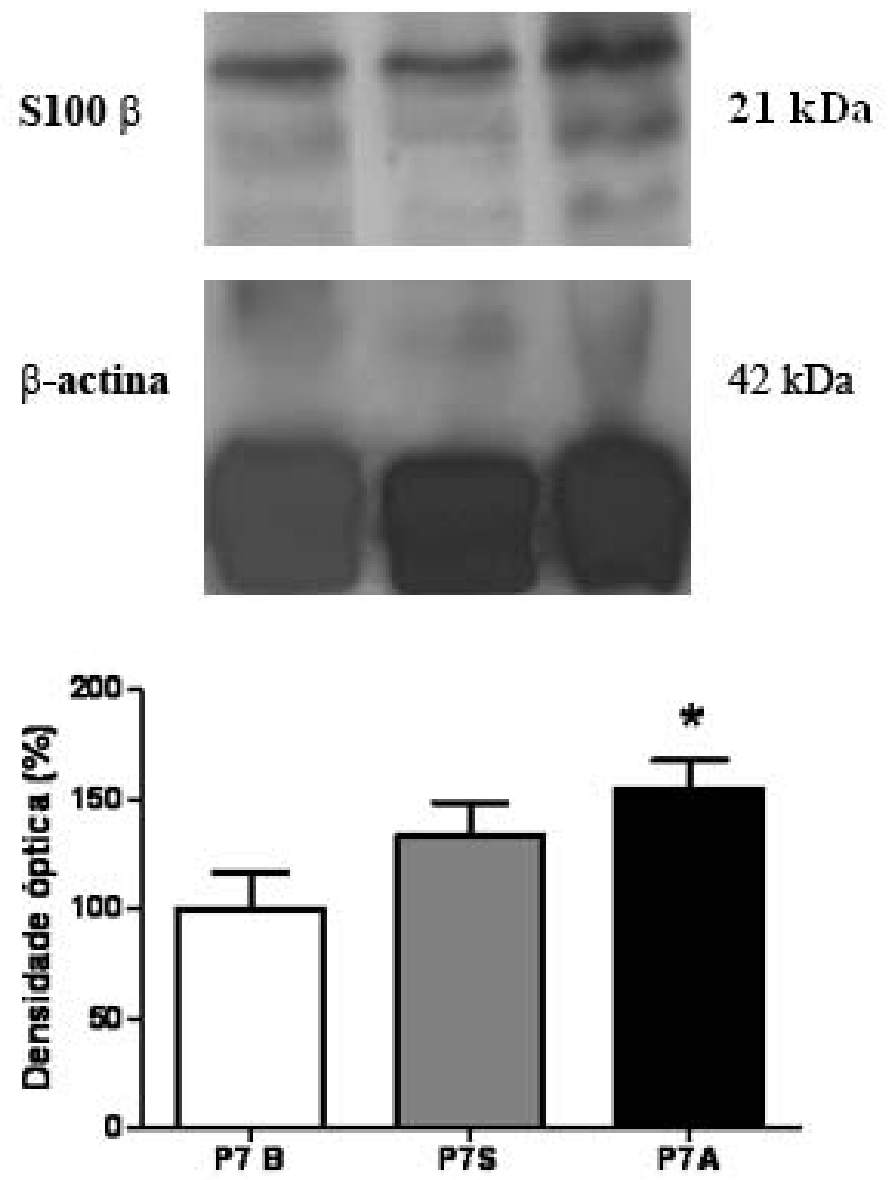

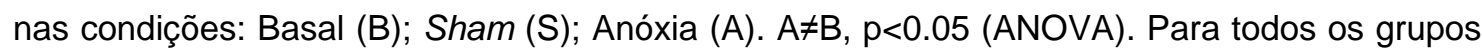
$n=8$.

Fonte: Allemandi, (2011).

\subsubsection{Análise por Western blot para S100ß-IR na Formação Hipocampal, grupos $P 2$ vs $P 7$, condições: $B, S$ e $A$}

Podemos observar a densidade óptica das bandas marcadas para S100ß, na Formação Hipocampal, que P7 S apresentou 7,1\% a mais em comparação às bandas de P2 S, mas não foi considerada significante essa diferença. O grupo P7 A apresentou 14,6\% a mais em comparação às bandas de P2 A, mas não foi considerada significante essa diferença (Tabela 7, Figura 29). 
Tabela 7- Média e desvio padrão da densidade óptica (\%) obtida na quantificação de células S100ß-IR por Western Blot, em ratos do grupo P2 e P7, nas condições: Basal (B), Sham (S) e Anóxia (A)

\begin{tabular}{lll}
\hline & \multicolumn{1}{c}{ P2 } & P7 \\
\hline Basal & $100,0 \% \pm 29,7 \%$ & $100,0 \% \pm 47,4 \%$ \\
Sham & $126,2 \% \pm 30,2 \%$ & $133,3 \% \pm 43,3 \%$ \\
Anóxia & $140,3 \% \pm 24,7 \%{ }^{\#}$ & $154,9 \% \pm 37,0 \%{ }^{\#}$ \\
\hline - $\quad$ P2 vs P7, ${ }^{\#}$ vs. Basal, ${ }^{\$}$ vs. Sham, ANOVA, p<0.05. Para todos os grupos $n=8$
\end{tabular}

Figura 29- Gráfico da média e desvio padrão da DO (\%) obtida na quantificação de células S100ß-IR por Western Blot, na Formação Hipocampal em ratos $\mathrm{P} 2$ e $\mathrm{P} 7$

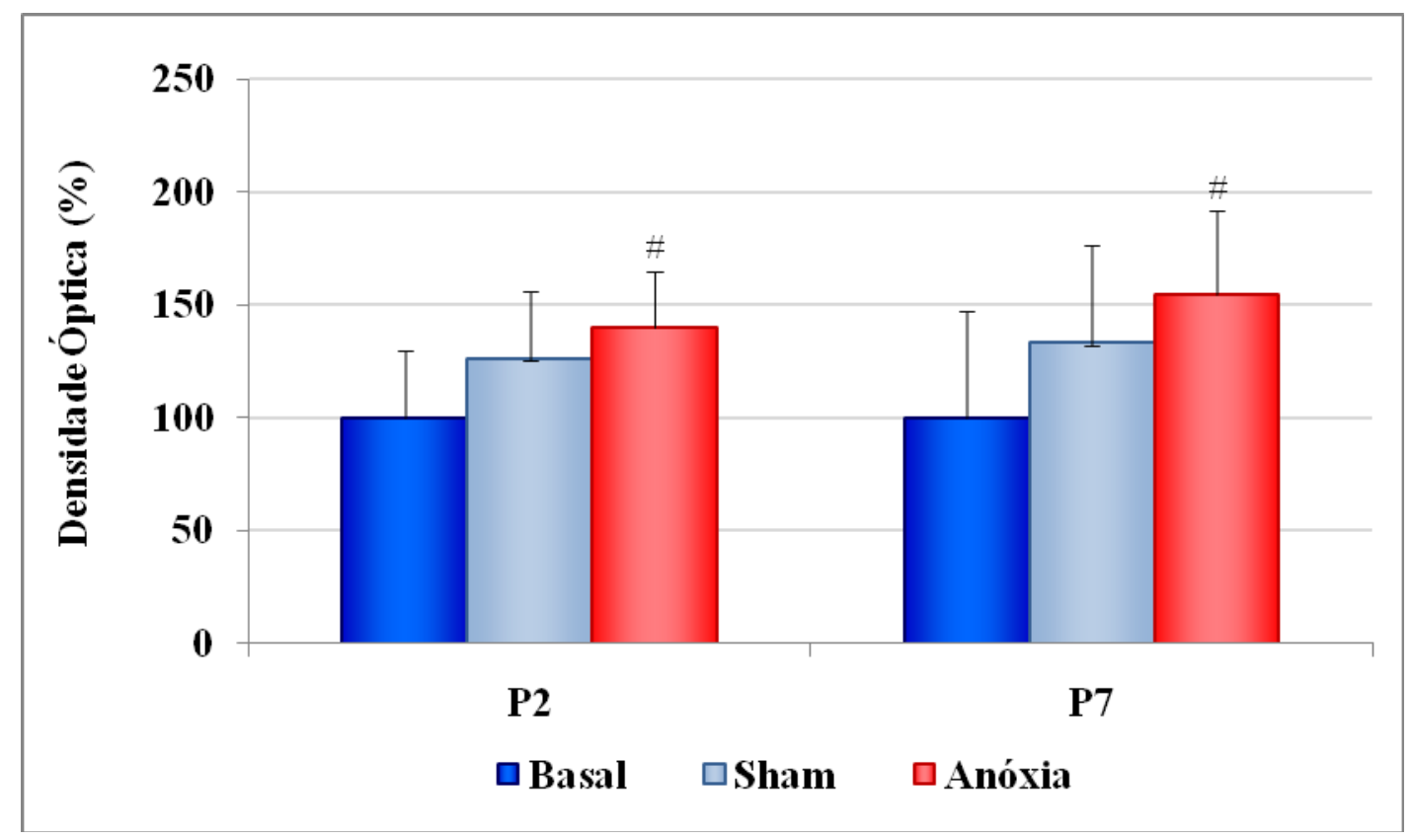

nas condições: Basal (B), Sham (S) e Anóxia (A). *P2 vs. P7, ${ }^{*}$ vs. Basal, ${ }^{\$}$ vs. Sham, ANOVA, $p<0.05$. Para todos os grupos $n=8$.

Fonte: Allemandi, (2011). 
5 DISCUSSÃO 


\subsection{S100ß-IR, na Formação Hipocampal}

A escolha de rato $\mathrm{P} 2 \mathrm{2h}$ para os estudos na Formação Hipocampal foi definida conforme estudos e resultados obtidos no NTS com S100ß-IR e FosIR.

A literatura reporta que alguns segundos de anóxia podem provocar inconsciência e poucos minutos levam à morte neuronal, causando lesões irreversíveis no tecido nervoso (POWELL et al., 1998; VIZEK et al., 1987, 2001). Nessa condição, são relatados ainda distúrbios neuro-comportamentais, tais como prejuízo no aprendizado e na memória espacial (DELL'ANNA et al., 1997; IUVONE et al., 1996), que persistem por toda vida (CAPUTA et al., 2005; BUWALDA et al., 1995). Nosso modelo validado indicou que essa situação é verdadeira para o NTS, quando o neonato é exposto a 25 minutos de privação de oxigênio (TAKADA et al., 2011).

Ao relacionarmos a privação de oxigênio no cérebro do ser humano, as seqüelas podem ser motoras, cognitivas e comportamentais, podendo variar conforme a gravidade da lesão (OLIVEIRA-ALONSON e SILVEIRA, 2007). Crianças podem apresentar: retardo mental, paralisia cerebral, epilepsia, deficiências auditivas e visuais (JOHNSON et al., 2002). A existência de marcador de danos cerebrais pode atuar positiva e preventivamente nessas situações. S100ß atua nesse sentido, pois exerce papel como potencial proteína biomarcadora de danos ou disfunções cerebrais, conforme demonstrado por alterações nos valores séricos e no liquido cérebro-espinhal (MRAK E GRIFFIN, 2001).

Os mecanismos de sua ação podem estar associados a sua propriedade de proteína ligante de cálcio. Assim $\mathrm{S} 100 \beta$ em células do SNC podem tamponar excesso de $\mathrm{Ca}^{2}{ }^{2}$ e potencialmente socorrer e prevenir morte neuronal (BARGER, 1995). S100 $\beta$ também participa no desenvolvimento do encéfalo (STAGAARD JANOS, 1991) e estimula a proliferação e maturação astroglial (SELINFREUND, et al., 1991), promove sobrevivência neuronal (BARGER, 1995), influencia a organização do citoesqueleto, ou seja, seus filamentos atuam na extensão neurítica e por isso tem sido reportada como fator trófico e neuro-trófico (ROTHERMUNDT et al., 2003; DONATO, 2003; 1988; 1985; SORCl et al., 1998; WINNINGHAM-MAJOR et al., 1989). Esses 
eventos relacionados à plasticidade do tecido nervoso podem ser alterados se modificações nos níveis de S100ß ocorrer com os ratos neonatos (CUNHA et al., 2007).

Inicialmente avaliamos alterações na glia após anóxia no NTS. Essa avaliação foi temporal, por 30 minutos, $2 \mathrm{~h}$ e $7 \mathrm{~h}$ pós estimulo, para conferir alterações nos teores de $\mathrm{S} 100 \beta$. Os resultados foram positivos para ratos $\mathrm{P} 2$ $2 \mathrm{~h}$, justificando assim nossa escolha. Observamos em P2 30 minutos houve muita variabilidade entre o mesmo grupo. O grupo P2 A $2 \mathrm{~h}$ apresentou aumento no número de células imunorreativas em relação ao P2 S $2 \mathrm{~h}$, o estímulo parece ter diminuído a tendência de variabilidade entre eles, enquanto o grupo P2 7 h não apresentou diferença significativa entre as condições A e S. Em estudos futuros é importante explorar outros intervalos como, uma hora, a fim de verificar se esse valor máximo do grupo anóxia é alcançado antes de 2 horas, e períodos superiores há 7 horas para verificar quando inicia 0 decréscimo da imunorreatividade.

Definidas as condições para explorar anóxia passamos às avaliações de desenvolvimento, agora com ratos P2 2 horas e P7 dias de vida, com técnicas imunoistoquímica em algumas regiões da Formação Hipocampal.

Diferenças na quantidade de células de S100ß-IR em diferentes fases de desenvolvimento encontradas entre os ratos P2 quando comparados aos ratos $\mathrm{P} 7$, indicam dinâmica diferenciada com o desenvolvimento. Poderíamos levar em consideração que excesso de $S 100 \beta$ pode desencadear disfunção neuronal e neuroinflamação e algumas vezes seus níveis são correlacionados com severidade de danos (VAN ELDIK et al., 2003). Como S100 $\beta$ também promove gliogênese e angiogênese, poderia estar sendo secretado para a matrix extracelular. Estes fenômenos podem indicar sua participação em regeneração de tecido nervoso.

Pesquisadores indicam que, de fato o numero aumentado de S100ß-IR reflete reação das células da glia ao estimulo nocivo, entretanto, não são conhecidos os mecanismos que regulam a expressão de $\mathrm{S} 100 \beta$ em astrócitos reativos, após lesão no SNC (CUNHA et al., 2007; ROTHERMUNDT et al., 2003; DUNN et al., 1995; REEVES et al., 1994). 
A formação hipocampal, por estar implicada no controle de várias funções cerebrais como memória e aprendizagem (ROGALSKA et al., 2006; DELL'ANNA et al., 1995b) é estrutura neural com altos graus de complexidade celular e funcional (KIMOTO et al., 2009). Ela é relatada como sendo uma das áreas mais susceptíveis à morte neuronal após privação de oxigênio, é a mais citada na literatura, (DELL'ANNA et al., 1995b). Estudos de nosso laboratório corroboram essas afirmações (ITO, 2010; ROGALSKA et al., 2006; CASOLINI et al., 2005; WAINWRIGHT et al., 2004; DELL'ANNA et al., 1995b).

Analisamos regiões da Formação Hipocampal, relembrando que estas possuem características anatômo-funcionais próprias e, portanto seja nos resultados, quanto na dimensão da grade a qual utilizamos para a contagem das células imunorreativas, permitiram visualizar os resultados obtidos.

Interessante diferença entre $\mathrm{CA} 3+\mathrm{CA} 2$ e $\mathrm{CA} 1$, com $\mathrm{P} 7 \mathrm{~S}<\mathrm{P} 7 \mathrm{~B}$ e $\mathrm{P} 2 \mathrm{~S}<\mathrm{P} 2 \mathrm{~B}$. Observamos comportamentos que indicaram alterações fisiológicas: como aumento freqüência cardíaca (tremores) e formação de urina (ocorrências que antecedem a perfusão: separação materna e fraterna; temperatura ambiente diferenciada do aconchego da gaiola). A barreira hemato-encefálica ainda não formada poderia estar refletindo, que o estímulo não foi suficiente para produzir S100 ou algum fator da cascata de produção, resultando $\mathrm{S}<\mathrm{B}$. Poderíamos concluir que a manipulação também foi suficiente para acarretar estresse no animal.

Ocorrência foi observada, em diferentes regiões da formação hipocampal (CA1, CA3+CA2 e DG), apresentando P2 A > que P2 B e P2 S. Observamos que analisar ratos neonatos 2 horas após estimulo anóxico classifica este mesmo estímulo como agudo e o potencializa dando-lhe condições de causar danos ao tecido novo, com reação clara e evidente de S100ß-IR atuando na proliferação agindo como neuroprotetor. Em P7 A < em relação ao P7 B e P7 S diante do estimulo anóxico crônico, causam danos ao tecido, com reação clara e evidente de perda celular.

Os astrócitos apresentam capacidade proliferativa quando ocorrem lesões no tecido nervoso, situação em que se multiplicam e se deslocam para as proximidades da lesão. Antes, porém devido a sua capacidade de produzir fatores tróficos, que liberados na região da lesão, contribuem para a sobrevida 
dos neurônios e propiciam que antígenos exteriorizados na membrana ativem células do sistema imunitário (CERUTTI e CHADI, 2000; KIMOTO et al., 2009). Sendo assim, os resultados poderiam estar sendo discutidos numa possível visão de ações parácrinas tróficas de astrócitos reativos, mediados por S100ß desencadeando eventos de reparos no local, no caso regiões da formação hipocampal mais sensíveis à anóxia, bem como dirigindo trofismo e plasticidade nessas regiões.

Observamos na região CA3+CA2, P2 B não houve diferença significante em relação a P7 B e CA1, enquanto que na região DG apresentou o grupo P2 B $1 / 3<$ em relação a P7 B. É do conhecimento que a gliogênese antecede a neurogênese e por ausência de informações sobre alterações de desenvolvimento sobre glia no hipocampo de ratos (KIMOTO, 2009), faremos analogias, informando que as células piramidais de CA3+CA2 são geradas durante a ultima semana de gestação (BAYER, 1980a, b; SCHLESSINGER, 1978); células granulares DG, se originam principalmente nas primeiras três semanas após o nascimento (mas continuam produzindo, porem lentamente, durante a vida) (KAPLAN e BELL, 1984, 1983; BAYER, 1980a, b); em CA1, por ser região mais sensível à hipóxia (anóxia) que as demais regiões, além de ser a região cerebral que inicialmente manifesta patologia e perda neuronal (KIMOTO, 2009; WEST, 2004).

O presente estudo demonstrou substancial ativação de S100 $\beta$-IR no encéfalo de ratos neonatos, P2 e P7, em camadas, nas regiões do Corno de Amomm e Giro Denteado da Formação Hipocampal.

Particularmente vulnerável, a região do hilus do hipocampo tem sido implicada em estudos examinando influencias ambientais, incluindo isquemia (MATSUYAMA et al., 1993; JOHANSEN et al., 1987, 1986); estudos epiléticos (SLOVITER, 1987); trauma craniano (LOWENSTEIN et al., 1992) e má nutrição em estruturas do cérebro (MIKI et al., 2000; ANDRADE et al., 1995).

$\mathrm{Na}$ verdade, a natureza da lesão é um fator determinante e os procedimentos subseqüentes devem ser considerados em relação a ela. $O$ corno de Amonn, CA1, região mais sensível à hipóxia (anóxia) que as demais, é uma região cerebral que inicialmente manifesta patologia e perda neuronal como na doença de Alzheimer (KIMOTO et al., 2009; WEST et al., 2004). Em análises de nosso laboratório observamos nas camadas de CA1 a presença de 
fibras S100ß-IR, que poderiam estar evidenciando correlação entre a alta imunorreatividade destas camadas e funções da $S 100 \beta$ na neuroplasticidade da formação hipocampal (NOGUEIRA et al., 2009).

O exato mecanismo envolvido em determinar se as células vão para apoptose ou não, e o grau de vulnerabilidade que proporcionam às células para suportar morte celular, ainda é pobremente compreendido até o presente. (MIKI et al., 2000).

Além das características morfológicas, os astrócitos têm sido identificados mais recentemente pela expressão da proteína que Ihes é exclusiva, a chamada proteína ácida fibrilar glial (GFAP). A análise dos cortes histológicos da S100ß-IR e GFAP na formação hipocampal ao indicar colocalização desses dois anticorpos por epifluorescência, confirma o fenótipo astrocitário das células imunorreativas.

Células identificadas como astrócitos por marcação imunoistoquímica (ABC-DAB) para GFAP são facilmente identificadas pela coloração marrom de seu citoplasma e tem sido encontrada ao redor de vasos sanguíneos, ao longo da superfície do SNC constituindo a membrana limitante da glia, abaixo das células ependimárias, bem como em proximidade a corpos celulares neuronais ou dispersas pelo parênquima (BONDAN et al., 2003). Encontramos diferença significativa no grupo $P 2$ condição $A$, em relação ao grupo $P 2$ condição $B$, o mesmo ocorre no grupo P7 A em relação ao grupo P7 B. Dessa forma, características como especificidades, condições de manuseamento, revelam-se essenciais para a interpretação de resultados, bem como para a avaliação da qualidade da técnica.

Independentemente da causa da agressão no SNC, o reparo do tecido ocorre com a participação astrocitária em maior ou menor grau, essa reação pode incluir o aumento do número de astrócitos e/ou de suas dimensões, além de outras alterações estruturais e funcionais, como espessamento dos feixes de filamentos gliais e conseqüente aumento da intensidade de marcação para a GFAP (EDDLESTON e MUCKEM 1993). Estes fenômenos têm sido referidos como astrocitose fibrilar reacional (BIGNAMI e DAHL, 1994; EDDLESTON e MUCKEM 1993). O aumento da imunorreatividade para a GFAP acompanha vários tipos de agressão nervosa, tais como isquemia, trauma e desmielinização (PETITO et al., 1990). Mudanças nos filamentos intermediários 
dos astrócitos pode ser indicação de alterações reativas destas células a agressão do tecido nervoso.

Para reforçar nossos estudos e resultados, utilizamos a técnica de Western blot, dissecando bilateralmente toda a formação hipocampal. Nossos resultados, por imunoistoquímica após análises imunorreativas em algumas regiões da formação hipocampal e por Western blot em área total, apresentaram diferenças regionais na primeira quando comparada a análise da formação hipocampal como um todo.

$\mathrm{Na}$ imunoistoquímica obtivemos resultados em P7 A com diminuição significante em todas as regiões estudadas. Fica a questão: houve morte celular? Enquanto isso no Western blot obtivemos resultados em P7 A com aumento significante. Acreditamos que este resultado de Western blot, por ser leitura de área total da formação hipocampal, poderia estar mascarando diferenças regionais, resultados estes, obtidos em imunoistoquímica.

Existem diferenças biológicas de desenvolvimento entre rato P2 e P7 e observamos diferenças morfológicas no tecido nervoso da formação hipocampal, entre os animais estudados, evidenciando grupo P2 menor que o grupo P7, em todas as condições estudadas. Devido este fatores, na técnica de Western blot os volumes de amostra, carregados em cada poço, foram ajustados (a partir da quantificação, ABS por Espectrofotometria) para que a mesma quantidade de proteína $(75 \mu \mathrm{g})$ fosse alcançada em todos os grupos e condições estudadas, portanto foi necessário obter duas amostra de cada grupo nas diferentes condições. Na verdade, devemos ressaltar que diferentes períodos de desenvolvimento, em diferentes regiões (como nosso estudo com imunoistoquímica), podem ter diferentes graus de vulnerabilidade, conforme fase em que se encontra e capacidade de adaptação à exposição ao estimulo anóxico que utilizamos, portanto a natureza da lesão é um fator importante e procedimentos, devem ser considerados em análise no Sistema Nervoso.

\subsection{S100ß-IR e sua relação Neurônio vs Glia na Formação Hipocampal}

Atividade neuronal pode desencadear comunicação da glia, de célula para célula, tais como modulações de sinais de cálcio (DANI et al., 1992), essa interação neurônio-glia representa importância chave no desenvolvimento e 
atividade funcional hipocampal (KIMOTO et al., 2009; RICKMANN et al., 1987). No cérebro existem mais células da glia que neurônios e entre a glia, astrócitos são os mais numerosos (LENT, 2009; KIMELBERG e NORENBERG, 1989).

Os astrócitos desempenham papel crucial na manutenção da fisiologia normal cerebral durante o desenvolvimento e na idade adulta. Anteriormente eram creditados para garantir manutenção alimentando funções nas sinapses, hoje está claro que células da glia contribuem ativamente no desenvolvimento de sinapse (OLIET e MOTHET, 2009; CHRISTOPHERSON et al., 2005; SLEZAK e PFREIGER, 2003), na transmissão sináptica (JOURDAIN et al., 2007; SERRANO et al., 2006; PANATIER et al., 2006; PASCUAL et al., 2005; GORDON et al., 2005) e excitabilidade neuronal (TIAN et al., 2005; ÂNGULO, 2004; FELLIN et al., 2004).

Estímulos nocivos podem causar proliferação celular possivelmente para resistir à apoptose ou à catástrofe mitótica, sabemos que células tronco e progenitoras têm uma proeminente capacidade proliferativa, sendo por isso altamente vulneráveis a qualquer estimulo que cause dano ao cérebro (HELLSTRÖM et al., 2009). No entanto, a sobrevida ou morte neuronal depende de vários mecanismos de sinalização, não muito bem conhecidos, e que o astrócito também está envolvido no processo (STRÖMBERG et al., 1986). Atualmente está claro que células da glia, por intermédio de astrócitos, sintetizam D-amino endógeno, é a D-Serina, auxiliando no processo de sinalização (HENNEBERGER et al., 2010; OLIET e MOTHET, 2009; JOURDAIN et al., 2007; SERRANO et al., 2006; PANATIER et al., 2006; PASCUAL et al., 2005; GORDON et al., 2005).

Na maior parte do cérebro, a geração de neurônio está completa até o nascimento, de qualquer maneira em poucas regiões, como DG da formação hipocampal e parede ventricular lateral, a maioria dos neurônios é gerada após o nascimento (KIMOTO et al., 2009), entretanto neurogênese contínua é observada ao longo da vida (HELLSTRÖM et al., 2009). Pesquisadores se ressentem quanto a ausência de informações sobre as alterações de desenvolvimento dos astrócitos, bem como microglias e oligodendrócitos no hipocampo de ratos (KIMOTO et al., 2009).

Poderíamos citar que, neurogênese pósnatal no DG representa uma função critica no desenvolvimento normal cognitivo, especificamente nas 
funções duplas de aprendizagem e memória. Vários estudos têm mostrado lesões cerebrais, durante períodos pósnatal ou adulto, abalando a neurogênese quase completamente e apontando especificamente para células tronco e progenitoras e desse modo, contribuindo para disfunção da memória (HELLSTRÖM et al., 2009). Postula-se que astrócitos (e microglia) ativados exerçam influência nos eventos tróficos nesses locais mais sensíveis à agressão, assim como nas vias neuronais lesadas (GIULIAN et al., 1996; LEME e CHADI, 2001).

O exato mecanismo envolvido em determinar se células vai para apoptose ou não, e o grau de vulnerabilidade que proporcionam às células para suportar morte celular, ainda é pobremente compreendido até o presente. (MIKI et al., 2000). 
6 CONCLUSÕES 
Este estudo evidenciou pelo uso da imunorreatividade de $\mathrm{S} 100 \beta$, que a anóxia neonatal afeta astrócitos do encéfalo de ratos neonatos. Tendo sido observada resposta que varia, conforme as condições avaliadas, o período após o estimulo e conforme o estágio de maturação da região considerada. Importante observar que as células S100ß-IR eram também GFAP-IR.

Interessante é observar que os astrócitos apresentaram aumento de S100ß-IR do NTS a 2 horas após anóxia neonatal, similar a ativação neuronal observada com a Fos-IR neste mesmo núcleo, evidenciando ativação paralela glia e neurônio.

A S100ß-IR aumentada em P2 A indica resposta astrocitária aguda ao estimulo como ação neuroprotetora, sendo que em P7 A S00ß-IR diminuída, parece refletir mecanismos alterados na IR ou menor numero de astrócitos, imunorreativos à $S 100 \beta$.

A aparente contradição entre os resultados da IR na avaliação imunoistoquímica (anóxia aumentada S100ß-IR em P2 e diminuida em P7) e por Western blot (a S100 $\beta$ aumentada no grupo anoxia em P2 e P7), pode advir de que a imunoistoquímica conta células e o Western blot avalia teor protéico. Entretanto nos dados de Western blot deve se considerar que o tecido foi utilizado como um todo e eventualmente mascara os dados das diferentes regiões avaliadas por imunoistoquímica. 
REFERÊNCIAS 
ALBERTS, B.; BRAY, D.; LEWIS, J.; RAFF, M.; ROBERTS, K.; WATSON, J. D. Cell junctions, cell adhesion and the extracellular-matrix. In:

Molecular

biology of the cell. 3.ed. New York: Garlard Publishing; 1994. p. 949-1009..

AMARAL, D. G. e WITTER, M. P. Hippocampal Formation. In: George, P. The rat nervous system. 2. ed. Sydney: Academic Press; 1995. Cap. 21, p. 443493.

ANDERSON, R. E.; HANSSON, L. O.; NILSSON, O.; DIJLAI-MERZOUG, R.; SETTERGREN, G. High Serum S100 $\beta$ levels for trauma patients without head injuries. Neurosurgery, v. 48, p. 1255-1260, 2001b.

ANDRADE, J.; MADEIRA, M.; PAULA-BARBOSA, M. Effects of long-term malnutrition and rehabilitation on the hippocampal formation of the adult rat. $A$ morphometric study. J. Anat., v. 187, p. 379-393, 1995

ANGULO, M. C.; KOZLOV, A. S.; CHARPAK, S.; AUDINAT, E. Glutamate released from glial cells synchronizes neuronal activity in the hippocampus. $\mathbf{J}$. Neurosci., v. 24 (31), p. 6920-6927, 2004.

ANTHONY, T. E.; KLEIN, C.; FISHELL, G.; HEINTZ, N. Radial glia serve as neuronal progenitors in all regions of the central nervous system. Neuron, v. 41, p. 881-890, 2004.

ARAQUE, A.; MARTIN, E. D.; PEREA, G.; ARELLANO, J. L.; BUNO, W. Synaptically released acetylcholine evokes Ca2+ elevations in astrocytes in hippocampal slices. J. Neurosci., v. 22(7), p. 2443-2450, 2002.

BALLANYI, K.; KUWANA, K.; VOELKER, S.; MORWIETZ, A.; RITCHER, D. W. Developmental changes in the hypoxia tolerance of the in vitro respiratory network of rats. Neurosci. Let., v. 148, p.141-144. 1993.

BAUDIER, J. e COLE, R. D. Interactions vetween the microtubule-associated proteins and $\mathrm{S} 100 \mathrm{~b}$ regulate 7 protein phosphorylation by the Ca-calmodulindependent protein kinase II. J. Biol. Chem., v. 263, p. 5876-5883, 1988.

BAYER, S. A. Development of the hippocampal region in the rat. I. Neurogenesis examined with ${ }^{3} \mathrm{H}$-thymidine autoradiography. J. Comp. Neurol., v. 190 , p. $87-114,1980$ a.

De acordo com:

ASSOCIAÇÃO BRASILEIRA DE NORMAS

TÉCNICAS. NBR 6023: informação e

documentação: referências: elaboração.

Rio de Janeiro, 2002. 
BAYER, S. A. Development of the hippocampal region in the rat. II. Morphogenesis during embryonic and early postnatal life. J. Comp. Neurol., v. 190, p.115-134, 1980b.

BERTSCH, T.; CASSARIN, W.; KRETSCHMAR, M.; ZIMMER, W.; WALTER, S.; SOMMER, C.; MUEHLHAUSER, F.; RAGOSCHKE, A.; KUEHL, S.; SCHMIDT, R.; POHLMANN-EDEN, B.; NASSABI, C.; NICHTERLEIN, T.; FA_BENDER, K. Protein S-100 $\beta$ : a serum marker for ischemic and infectious injury of cerebral tissue. Clin. Chemi. Lab. Med., v. 39, p. 319-323, 2001.

BHATTACHARYYA, A.; OPPENHEIM, R. W.; PREVETTE, D.; MOORE, B. W.; BRACKENBURY, R.; RATNER, N. S100 is present in developing chicken neurons and schwann cells and promotes motor neuron survival in vivo. $\mathbf{J}$. Neurobiol., v. 23, p. 451-66, 1992.

BIANCHI, R.; GARBUGLIA, M.; VERZINI, M.; GIAMBANCO, I.; DONATO, R. Mechanism of S100 Protein-Dependent Inhibition o GFAP Polymerization. B. B. A, v.1223, p. 354-360,1994.

BICKLER, P. E.; GALLEGO, S. M.; HANSEN, B. M. Developmental changes in intracellular calcium regulation in rat cerebral cortex during hypoxia. J. Cerebr. Blood Flow Metabol., v. 13, p. 811-819, 1996.

BIGNAMI, A. e DAHL, D. Glial cells in the central nervous system and their reaction to injury. Austin: Landes, 1994.

BITTENCOURT, J. C; ELIAS, C. F. Métodos em Neurociências. $1^{\text {a }}$ Ed. Roca. São Paulo: 2008. Cap. 11: Métodos Quantitativos Estruturais e de Dosagens em Neurociências.

BLOOM, SL.; SWINDLE, R. G.; MCINTIRE, D. D.; LEVENO, K. J. Fetal pulse oximetry: duration of desaturation and intrapartum outcome. Obst. \& Ginecol., v. 93, n. 6, p. 1036-1040, 1999.

BOMONT, L.; BILGER, A.; BOYET, S.; VERT, P.; NEHLIG, A. Acute hypoxia induces pecific changes in local cerebral glucose utilization at different postnatal ages in the rat. Devel. Brain Res., v. 66, p. 33-45, 1992.

BONDAN, E. F.; LALLO, M. A.; DAGLI, M. L. Z.; SANCHEZ, M.; GRAÇA, D. L. Investigation into the astrocytic immunoreactivity to GFAP e vimentin in the 
brainstem of Wistar rats submitted to the ethidium bromide gliotoxic model. Arq. Neuropsiqui., v.61(3), p.01-10, 2003.

BUWALDA, B.; NYAKAS, C.; VOSSELMAN, H. J.; LUITEN, P. G. M. Effects of early postnatal anoxia on adult learning and emotion in rats. Behav. Brain Res., v. 67, p. 85-90, 1995.

CAMPOS, L. M. G. "Estudo da distribuição da proteína S100b no encéfalo de ratos". 2007. 112 f. Dissertação (Mestrado em Ciências Morfofuncionais) Instituto de Ciências Biomédicas, Universidade de São Paulo, São Paulo.

CAPUTA, M.; ROGALSKA, J.; WENTOWSKA, K.; NOWAKOWSKA, A. Perinatal asphyxia, hyperthermia and hyperferremia as factors inducing behavioural disturbances in adulthood: A rat model. Behav. Brain Res., v.163, p. 246-256, 2005.

CASOlinI, P.; ZUENA, A. R.; CINQUE, C.; MATTEUCCI, P.; ALEMÀ, G. S.; ADRIANI, W.; CARPINELLI, G.; SANTORO, F.; ALLEVA, E.; BOSCO, P.; NICOLETTI, F.; LAVIOLA, G.; CATALANI, A. Sub-neurotoxic neonatal anoxia induces subtle behavioural changes and specific abnormalities in brain group-I metabotropic glutamate receptors in rats. J. Neurochemi., v. 95, n. 1, p. 137145, 2005.

CERUTTI, S. M. e CHADI, G. S100 immunoreactivity is increased in reactive astrocytes of the visual pathways followinag a mechanical lesion of the rat occipital cortes. Cell Biol. Int., v. 24, p. 35-49, 2000.

CHADI, G.; TINNER, B.; AGNATI, L. F.; FUXE, K. Fasic fibroblast growth factor (bFGF. FGF-2) immunoreactivity exists in the noradrenaline, adrenaline and 5ht nerve cells of the rat brain. Neurosci. Lett., v. 160, p. 171-176, 1993c.

CHERICI, G.; ALESIANI, M.; PELLEGRINI-GIAMPIETRO, E.; MORONI, F. Ischemia does not induce the release of excitotoxic amino acids from the hippocampus of newborn rats. Devel. Brain Res., v. 60, p. 235-240, 1991.

CHRISTOPHERSON, K. S.; ULLIAN, E. M.; STOKES, C. C.; MULLOWNEY, C. E.; HELL, J. W.; AGAH, A.; LAWLER, J.; MOSHER, D. F.; BORNSTEIN, P.; BARRES, B. A. Thrombospondins are astrocyte-secreted proteins that promote CNS synaptogenesis. Cell, v. 120(3), p. 421-433, 2005. 
CIRULLI, F.; BONSIGNORE, L. T.; VENEROSI, A.; VALANZANO, A.; CHIAROTTI, F.; ALLEVA, E. Long-term effects of acute perinatal asphyxia on rat maternal behavior. Neurobiol. Teratol., v. 25, p. 571-578, 2003.

CONNER, J. M.; LAUTERBORN, J. C.; YAN, Q.; GALL, C. M.; VARON, S. Distribution of brain-derived neurotrophic factor (BDNF) protein and mRNA in the normal adult rat CNS: evidence for anterograde axonal transport. J. Neurosci. , v. 17 p. 2295-2313, 1997.

CUNHA, J. C.; LEVY, B. F. A.; LUCA, B. A.; ANDRADE, M. S. R.; GOMIDE, V. C.; CHADI, G. Response of reactive astrocytes containing $S 100 \beta$ protein and fibroblast growth factor-2 in the border and in the adjacent preserved tissue after a contusion injury of th spinal cord in rats: implications for wound repair and neuroregeneration. Wound Rep. Reg., v. 15, p.134-146, 2007.

DAHLQUIST, G. e PERSSON, B. The rate of cerebral utilization of glucose, ketone bodies, and oxygens: a comparative in vivo study of infant and adult rats. Pediatric Res., v. 10, p. 910-917, 1976.

DANI, J. W.; CHERNJAVSKY, A.; SMITH, S. J. () Neuronal activity triggers calcium waves in hippocampal astrocyte networks. Neuron v. 8, p. 429-440, 1992. (doi:10.1016/0896-6273(92)90271-E).

DECKER, M. J.; CONRAD, K. P.; STROHL, K. P. Noninvasive oximetry in the rat. Biomed. Instrum. Technol., v. 23, n. 3, p. 222-228, 1989.

DEITMER, J. W.; VERKHRATSKY, A. J.; LOHR, C. Calcium signalling in glial cells. Cell Calcium, v. 24(5-6), p. 405-416, 1998.

DELL'ANNA, E.; IUVONE, L.; CALZOLARI, S.; GELOSO, M. C. Effect of acetylL-carnitine on hyperactivity and spatial memory deficits of rats exposed to neonatal anoxia. Neurosci. Lett., v. 223, p. 201-205, 1997.

DELL'ANNA, E.; CHEN, Y.; LOIDL, F.; ANDERSSO, N. K.; LUTHMAN, J.; GOINY, M.; RAWAL, R.; LINDGREN, T.; HERRERA-MARSCHITZ, M. ShortTerm Effects of Perinatal Asphyxia Studied with Fos-Immunocytochemistry and in Vivo Microdialysis in the Rat. Exp. Neurol., v. 131, p. 279-287, 1995.

DELL'ANNA, M. E.; GELOSO, M. C.; DRAISCI, G.; LUTHMAN, J. Transient Changes in Fos and GFAP Innumoreactivity Precede Neuronal Loss in the Rat 
Hippocampus Following Neonatal Anoxia. Exp. Neurol., v. 131, p. 144-156, $1995 b$.

DELL'ANNA, M. E.; CALZOLARI, S.; MOLINARI, M.; IUVONE, L.; CALIMICI, R. Neonatal anoxia induces transitory hyperactivity, permanent spatial memory deficits and CA1 cell density reduction in developing rats. Behav. Brain Res., v. 45, n. 2, p. 125-134, 1991.

DELEUZE, C.; DUVOID, A.; HUSSY, NProperties and glial origin of osmoticdependent release of taurine from the rat supraoptic nucleus. J. Physiol., v. 507 (Pt 2), p. 463-471, 1998.

DIB, K.; EL JAMALI, A.; JACQUEMIN, C.; CORREZE, C. Cyclic AMP Regulation of Messenger RNA Level of Stimulatory GTP Binding Protein Gs alpha. Isoproterenol, Forskolin and 8-Bromoadenosine 3': 5'- Cyclic Monophosphate Increase the Level of Gs Alpha mRNA in Cultered Astroglial Cells. Eur. J. Biochem., v. 219, p. 529-537, 1994.

DOETSCH, F. The glial identity of neural stem cells. Nat. Neurosci., v. 6, p. 1127-1134, 2003.

DONATO, R. Intracellular and extracellular roles of S-100 proteins. Micros. Res. Tech., v. 60, p. 540-551, 2003. Review

DONATO, R. S-100: a multigenic family of calcium-modulated proteins of the EF-hand type with intracellular and extracellular functional roles. Int. J. Bioch. Cell Biol., v. 33, p. 637-668, 2001.

DONATO, R. Funcional roles of S100 proteins, calcium-binding protens o EFhand type. Biochin. Biophys. Acta, v. 1450, p. 191-231, 1999.

DONATO, R. Calcium-independent, pH-regulated effects of S-100 proteins on assembly-disassembly of brain microtubule protein in vitro. J. Biol. Chem., v. 263, p. 106-110, 1988.

DONATO, R. Calcium-sensitivity of brain microtubule proteins in the presence of S-100 proteins. Cell Calcium, v. 6, p. 343-361, 1985.

DUNN, R.; LANDRY, C.; O'HANLON, D.; DUNN, J.; ALLORE, R.; BROWN, I.; MARKS, A. Reduction in S100 protein beta subunit mRND in C6 rat glioma cells 
following treatment with anti-microtubular drugs. J. Biol. Chem., v. 262, p. 3562-3566, 1995.

EDDLESTON, M. e MUCKEM, L. Molecular profile of reactive astrocytes implications for their role in neurologic disease. Neuroscience, v. 54, p.15-36, 1993.

ENG, L. F. An acidic protein isolated from fibrous astrocytes. Brain Res., v. 28, p. 351-354, 1971.

FEDOROFF, S. Prenatal ontogenesis of astrocytes. In: FEDOROFF, S. \& VERNADAKIS, A. (Eds). Astrocytes. New York: Academic Press, 1986. p. 3574.

FELLIN, T.; PASCUAL, O.; GOBBO, S.; POZZAN, T.; HAYDON, P. G.; CARMIGNOTO, G. Neuronal synchrony mediated by astrocytic glutamate through activation of extrasynaptic NMDA receptors. Neuron v. 43(5), p.729743, 2004.

FINLEY, J. C.; KATZ, D. M. The central organization of carotid body afferent projections to the brainstem of the rat. Brain Res. , v. 572, p. 108-116, 1992.

GIULIAN, D.; HAVERKAMP, L. J.; YU, J. H.; KARSHIN, W.; TOM, D.; LI, J.; KIRKPATRICK, J.; KUO, L. M.; ROHER, A. E. Specific domains of beta-amyloid from Alzheimer plaque elicit neuron killing in human microglia. J. Neurosci., v.16, p. 6021-6037, 1996

GIULIAN, D.; VACA, K.; CORPUZ, M. Brain glia release factors with opposing actions upon neuronal survival. J. Neurosci., v. 13, p. 29-37, 1993.

GIULIAN, D. e VACA, K. Inflammatory glia mediate delayed neuronal damage after ischemia in the central nervous system. Stroke, v. 24, p. 184-190, 1993.

GHANDOUR, M. S.; LANGLEY, O. K.; LABOURDETTE, G.; VINCENDON, G.; GOMBOS, G. Specific and artefactual cellular localizations o S100 protein: an astrocyte maker in rat cerebellum. Dev. Neurosci., v. 4 (1), p. 66-78, 1981.

GEGELASHVILI, G. e SCHOUSBOE, A. High affinity glutamate transporters: regulation of expression and activity. Mol. Pharmacol., v. 62, p. 6-15, 1997. 
GERLACH, R.; DEMAL, G.; KONIG, H. G.; GROSS, U.; PREHN, J. H.; RAABE, A.; SEIFERT, V.; KOGEL, D. Active secretion of S100b from astrocytes during metabolic stress. Neuroscience, v. 141 (4), p. 1697-1701, 2006.

GLOWINSKI, J.; MARIN, P.; TENCE, M.; STELLA, N.; GIAUME, C.; PREMONT, J. Glial Receptors and their Inervention in Astrocytocytic and Astrocyto-neuronal Interations. Glia, v. 11, p. 201-208, 1994.

GOLDMAN, S. Glia as neural progenitor cells. Trends Neurosc., v. 26, p. 590596, 2003.

GOMIDE, V. C. e CHADI, G. The trophic factors S100beta and basic fibroblast grown factor are increased in the forebrain reactive astrocytes of adult callosotomized rat. Brain Res., v. 835, p.162-174, 1999.

GORDON, G. R.; BAIMOUKHAMETOVA, D. V.; HEWITT, S. A.; RAJAPAKSHA, W. R.; FISHER, T. E.; BAINS, J. S. Norepinephrine triggers release of glial ATP to increase postsynaptic efficacy. Nat. Neurosc., v.8(8), p. 1078-1086, 2005.

GORENBERG, D. M.; PATTILLO, C.; HENDI, P.; RUMNEY, P. J.; GARITE, T. $J$. Fetal pulse oximetry: correlation between oxygen desaturation, duration, and frequency and neonatal outcomes. Am. J. Obst. Gynecol., v. 189, n. 1, p. 136138, 2003.

GOURINE, A. et al., "Astrocytes Control Breathing Through pH-Dependent Release of ATP” Science, 2010 (doi: 10.1126/science.1190721, 16/07/2010).

GRIFFIN, W. S. T.; SHENG, J. G.; ROYSTON, M. C.; GENTLEMAN, S. M.; MCKENZIE, J. E.; GRAHAM, D. I.; ROBERTS, G. W.; MRAK, R. E. Glialneuronal interactions in Alzheimer's disease: the potential role of a "cytokine cycle" in disease progression. Brain Pathol., v. 8, p. 65-72, 1998.

GRIFFIN, W. S.; YERALAN, O.; SHENG, J. G.; BOOP, F. A.; MRAK, R. E.; ROVNAGHI, C. R.; BURNETT, B. A.; FEOKTISTOVA, A.; VAN ELDIK, L. J. Overexpression of the neurotrophic cytokine S100beta in human temporal lobe epilepsy. J. Neurochem., v. 65, p. 228-233, 1995.

GRIFFIN, W. S. T.; STANLEY, L. C.; LING, C.; WHITE, L.; MACLEOD, V.; PERROT, L. J.; WHITE, III L.; ARAOZ, C. Brain interleukin 1 and S-100 
immunoreactivity are elevated in Down syndrome and Alzheimer disease. Proc. Natl. Acad. Sci. USA, v. 86, p. 7611-7615, 1989.

HADDAD, G. G. e DONELLY, D. F. $\mathrm{O}^{2}$ deprivation induces a major depolarization in brainstem neurons in the adult bua not in the neonate. J. Physiol. London, v. 429a, p. 411-428, 1990.

HARDER, T. e GERKE, V. The subcellular distribution of early endosomes is affected by the annexin II2p11 (2) complex. J. Cell Biol., v. 123, p. 1119-1132, 1993.

HARING, J. H.; HAGAN, A.; OLSON, J.; RODGERS, B. Hipocampal serotonin levels influence the expression of $S 100 \mathrm{~b}$ detected by immunocytochemistry. Brain Res., v. 631, p. 119-123, 1993.

HASHIMOTO, A.; OKA, T.; NISHIKAWA, T. Anatomical distribution and postnatal changes in endogenous free $\mathrm{D}$-aspartate and $\mathrm{D}$-serine in rat brain and periphery. Eur. J. Neurosci., v. 7(8), p. 1657-1663, 1995a.

HASHIMOTO, A.; OKA, T.; NISHIKAWA, T. Extracellular concentration of endogenous free $\mathrm{D}$-serine in the rat brain as revealed by in vivo microdialysis. Neuroscience, v. 66(3), p. 635-643, 1995b.

HAY, J. R. W. W.; RODDEN, D. J.; COLLINS, S. M.; MELARA, D. L.; HALE, K. A.; FASHAW, L. M. Reliability of conventional and new pulse oximetry in neonatal patients. J. Perinatol., v. 22, (5), p. 360-366, 2002.

HEIZMANN, C. W. Calcium binding $S 100$ proteins in the central nervous system. Neurochem. Res., v. 24, p. 1097-1100, 1999.

HELLSTRÖM, N. A. K.; ERIKSSON-BJÖRK, T.; BLOMGREN, K.; KUHN, H. G. Differential recovery of neural stem cells in the subventricular zone and dentate gyrus after ionizing radiation. Stem Cells, v. 27, p. 634-641, 2009.

HENNEBERGER, G.; PAPOULIN, T.; OLIET, S. H.; RUSAKOV, D. A. Longterm potentiation depends on release of $D$-serine from astrocytes. Nature, v. 463 (7278), p. 232-236, 2010. 
HIMEDA, T.; WATANABE, Y.; TOUNAI, H.; HAYAKAWA, N.; KATO, H.; ARAKI, $T$. Time dependent alterations of co-localization of $S 100 \beta$ and GFAP in the MPTP-treated mice. J. Neural Transm., v. 113, p. 1887-1894, 2006.

HU, J.; CASTELS, F.; GUEVARA, J. L.; VAN ELDIK, L. J. S100 stimulates inducible nitric oxide synthase activity and $m$ RNA levels in rat cortical astrocytes. J. Biol. Chem., v. 271, p. 2543-2547, 1996.

HU, J.; FERREIRA, A.; VAN ELDIK, L. J. S100 beta induces neuronal cell death throught nitric oxide release from astrocytes. J. Neurochem., v. 69, p. 2294-2299, 1997.

ITO, PH. "Avaliação comportamental de ratos submetidos à anoxia neonatal". 2010. 98 f. Dissertação (Mestrado em Neurociência) - Instituto de Psicologia, Universidade de São Paulo, São Paulo.

IUVONE, E. L.; GELOSO, M. C.; DELL'ANNA, E. Changes in Open Field Behavior, Spatial Memory, and Hippocampal Parvalbumin Immunoreactivity Following Enrichment in Rats Exposed to Neonatal Anoxia. Exp. Neurol., v. 139, p. 25-33, 1996.

JOHANSEN, F. F.; ZIMMER, J.; DIEMER, N. H. Early loss of somatostatin neurons in dentate hilus after cerebral ischemia in the rat precedes CA-1 pyramidal cell loss. Acta Neuropathol., (Berl) v. 73, p. 110-114. 1987.

JOHANSEN, F. F.; JORGENSEN, M. B.; DIEMER, N. H. Ischemic CA-I pyramidal cell loss is prevented by preischemic colchicine destruction of dentate gyrus granule cells. Brain Res., v. 377, p. 344-347, 1986.

JOHNSON, M. V.; NAKAJIMA, W.; HAGBERG, H. Mechanisms of Hypoxic Neuro-degeneration in the Developing Brain. Neuroscientist, v. 8, p. 212-220, 2002.

JOURDAIN, P.; BERGERSEN, L. H.; BHAUKAURALLY, K.; BEZZI, P.; SANTELLO, M.; DOMERCQ, M.; MATUTE, C.; TONELLO, F.; GUNDERSEN, V.; VOLTERRA, A. Glutamate exocytosis from astrocytes controls synaptic strength. Nat. Neurosc., v. 10, p. 331-339, 2007.

KAPLAN, M. S. e BELL, D. H.. Neuronal proliferation in the 9-month-old-rodentradioautographic study of granule cells in the hippocampus. Exp. Brain Res., v. 52, p. 1-5, 1983. 
KAPLAN, M. S. e BELL, D. H. Mitotic neuroblast in the 9-day-old and 11month-old rodent hippocampus. J. Neurosci., v. 4, p. 1429-1441, 1984.

KIM, J. S.; YOON, S. S.; KIM, Y. H.; RYU, J. S. Serial measurement of Interleukin-6, transforming growth factor, and S-100 protein in patients with acute stroke. Stroke, v. 27, p. 1553-1557, 1996.

KIMOTO, H.; ETO, R.; ABE, M.; KATO, H.; ARAKI, T. alterations of glial cells in the mouse hippocampus during postnatal development. Cell Mol. Neurobiol., v. 29, p. 1181-1189, 2009.

KIMELBERG, H. K. e NORENBERG, M. D. Astrocytes. Sci. Am., v. 260, p. 66$72,1989$.

KRJANC, D.; WEMLINGER, T. A.; NEFF, N. H.; HADJI CONSTANTINOU, M. Neonatal hypoxia: early neurotransmitter responses ans the consequences of treatment with GM1 ganglioside. J. Pharmacol. Esp. Ther., v. 271, p. 12991305, 1994.

LAMERS, K. J. B.; VAN ENGELEN, B. G. M.; GABREELS, F. J. M.; HOMMES, O. R.; BORM, G. F.; WEVERS, R. A. Cerebrospinal neuron-specific enolase, S100 and Myelin Basic Protein in neurological disorders. Acta Neurol. Scand., v. 92, p. 247-251, 1995.

LANTOS, P. L. Nervous system, muscle and eyes. Systemic pathology In: WEDER, R. O. Cytology of the normal central nervous system. Edinburg: Academic Press, 1990. p. 3-35.

LAVIOLA, G.; ADRIANI, W.; REA, M.; ALOE, L.; ALLEVA, E. Social withdrawal, neophobia, and stereotyped behavior in developing rats exposed to neonatal asphyxia. Psychopharmacology, v. 175, p. 196-205, 2004.

LEE, C. J.; MANNAIONI, G.; YUAN, H.; WOO, D. H.; GINGRICH, M, B.; TRAYNELIS, S. F. Astrocytic control of synaptic NMOA receptors. J. Physiol., v. 581, p. 1057, 2007.

LEME, RJ.; CHADI, G. Distant microglial and astroglial activation secondary to experimental spinal cord lesion. Arq. Neuropsiquiatr., v.59, p. 483-492, 2001. 
LEVITZKY, M. G. Fluxo sanguíneo aos pulmões. In: Fisiologia pulmonar. São Paulo: Manole, 2004. Cap. 4. p. 86-112.

LEVITSKY, D. A. e BARNES, R. H. Nutritional and environmental interactions in the behavioral development of the rat. Long-term effects. Science, v.176, p. 6872, 1976.

LIESI, P. e SILVER, J. Is astrocyte laminin involved in axon guidance in the mammalian CNS? Dev. Biol., v. 130, p. 774-785, 1988.

LOFTON, S. A. Differential diagnosis of genitourinari tumors using monoclonal antibodies to intermediate filament protein. Urology, v. 33, p. 433-439, 1989.

LOIDL, C.F.; GAVILANES, A. W. D.; VAN DIJK, E. H. J.; VREULS, W.; BLOKLAND, A.; VLES, J. S. H.; STEINBUSCH, H. W. M.; BLANCO, C. E. Effects of hypothermia and gender on survival and behavior after perinatal asphyxia in rats. Physiol. Behavior, v. 68, p. 263-269, 2000.

LOWENSTEIN, D. H.; THOMAS, M. J.; SMITH, D. H.; MCINTOSH, T. K. Selective vulnerability of dentate hilar neurons following traumatic brain injury: a potential mechanistic link between head trauma and disorders of the hippocampus. J. Neurosci., v. 12, p. 4846-4853, 1992.

LUCIANA PINATO; WILMA ALLEMANDI; LAURA K. ABE; RENATA FRAZÃO; ROELF J. CRUZ-RIZZOLO; JEFFERSON S. CAVALCANTE, MIRIAM S.M.O. COSTA; MARIA I. NOGUEIRA. A comparative study of cytoarchitecture and serotonergic afferents in the suprachiasmatic nucleus of primates (Cebus apella and Callitthrix jacchus) and rats (Wistar and Long Evans strains). Brain Res., v.1149, p.101-110, 2007.

MACHADO, G. F. e FIGUEIREDO, F. Filamentos intermediários. Med. Ribeirão Preto, v.29, p.104-113, 1996.

MARTIN, D. L. Synthesis and release of neuroactive substances by glial cells. Glia, v. 5, p. 81-94, 1992.

MARTINEAU, M.; BAUX, G.; MOTHET, J. P. D-serine signalling in the brain: friend or foe. Trends Neurosc., v. 29, p. 481-491, 2006. 
MATSUYAMA, T.; TSUCHIYAMA, M.; NAKAMURA, H.; MATSUMOTO, M.; SUGITA, M. Hilar somatostatin neurons are more vulnerable to an ischemic insult than CA1 pyramidal neurons. J. Cereb. Blood Flow Metab., v. 13, p. 229-234, 1993.

MERKLE, F. T. e ALVAREZ-BUYLLA, A. Neuronal stem cells in mammalian development. J. Cell Biology, 2006. (doi.10.1016/j.ceb.2006.09.008).

MICHETTI, F.; MASSARO, A.; MURAZIO, M. The nervous system-specific S100 antigen in cerebrospinal fluid of multiple sclerosis patients. Neurosci. Lett., v. 11, p. 171-175, 1979.

MIGHETI, A.; CORDERA, S.; BENDOTTI, C.; ATZORI, C.; PIVA, R.; SCHIFFER, D. S-100 protein is upregulated in astrocytes and motor neurons in the spinal cord of patients with amyotrophic lateral sclerosis. Neurosci. Lett., v. 261, p. 25-28, 1999.

MIKI, T.; HARRIS, S. J.; WILCE, P.; TAKEUCHI, Y.; BEDI, K. S. Neurons in the hilus region of the rat hippocampus are depleted in number by exposure to alcohol during early postnatal life. Hippocampus, v. 10, p. 284-295, 2000.

MILLER, R. F. D-Serine as a glial modulator of nerve cells. Glia, v. 47(3), p. 275-283, 2004.

MOORE, B. A soluble protein characteristic of the nervous system. B\&hem. Byophys. Res. Comm., v. 19, p. 739-744, 1965.

MORGANE, P. J.; AUSTIN-LAFRANCE, R.; BRONZINO, J.; TONKISS, J.; DIAZ-CINTRA, S.; CINTRA, L.; KEMPER, T.; GALLER, J. R. Prenatal malnutrition and development of the brain. Neuroscience Biology Behavior Revision, v. 17, p. 91-128, 1993.

MRAK, R. E.; GRIFFIN, W. S. T. The role of activated astrocytes and of the neurotrophic cytokine $\mathrm{S} 100 \mathrm{~b}$ in the pathogenesis of Alzheimer's disease. Neurobiol. Aging, v. 22, p. 915-922, 2001.

NAKAJIMA, W.; ISHIDA, A.; TAKADA, G. Anoxic and hypoxic immature rat model for measurement of monoamine using in vivo microdialysis. Brain Research Protocols, v. 3, p. 252-256, 1999. 
NEHLIG, A. e PEREIRA DE VASCONCELOS, A. Glucose and ketone body utilization by the brain of neonatal rats. Progr. Neurobiol., v. 40, p. 163-221, 1993.

NEWMAN, E. A. Glial cell inhibition of neurons by release of ATP. J. Neurosci., v. 23(5), p. 1659-1666, 2003.

NOGUEIRA MI, BARBIERI C, VIEIRA R, MARQUES ER, MORENO JE. A pratical device for histological fixative produces the limits formaldehyde deleterious effects in laboratory enviroments. J. Neurosci. Met., v. 72, p. 65-70, 1997.

NOGUEIRA, M. I.; ABBAS, S. Y.; CAMPOS, L. G.M.; ALLEMANDI, W.; LAWSON, P.; TAKADA, S.H. S100 $\beta$ protein expression: gender- and agerelated daily changes. Neurochem. Res., v. 34, p.1355-1362, 2009.

NORTON J.; JACKSON, P. G.; TAYLOR, P. M. Measurement of arterial oxygen-haemoglobin saturation in newborn lambs by pulse oximetry. Vet. Rec., v. 142 , n. 5, p. 107-109, 1998.

NYAKAS C, BUWALDA B, LUITEN PGM. Hypoxia and Brain Development. Prog. Neurobiol., v. 49, p. 1-51, 1996.

OLIET, S. H. R. E. e MOTHET, J. P. Regulation of N-Methyl-d-Aspartate receptors by astrocytic D-serine. Neuroscience, v.158, p. 275-283, 2009.

O'CALLAGHAN, J.P. Assessment of neurotoxicity: use of glial fibrillary acidic protein as a biomarker. Biomed. Environ. Sci., v. 4, p. 197-206, 1991.

OLIVEIRA-ALONSO, G. S.; SILVEIRA, V. C. Lesões encefálicas infantis adquiridas. In: FERNANDES, A. C.; RAMOS, A. C. R.; CASALIS, M. E. P.; HEBERT, S. K. (Ed). AACD Medicina e reabilitação: princípios e prática. São Paulo: Artes Médicas, 2007. p. 161-172.

PANATIER, A.; THEODOSIS, D. T.; MOTHET, J. P.; TOUQUET, B.; POLLEGIONI, L.; POULAIN, D. A.; OLIET, S. H. R. Glia-derived D-serine controls NMDA receptor activity and synaptic memory. Cell, v. 125, p. 775-784, 2006.

PASCUAL, O.; CASPER, K. B.; KUBERA, C.; ZHANG, J.; Revilla-Sanchez, R.; Sul, J. Y.; Takano, H.; Moss, S. J.; McCarthy, K.; Haydon, P. G. Astrocytic 
purinergic signaling coordinates synaptic networks. Science, v. 310(5745), p. 113-116, 2005.

PASTI, L.; VOLTERRA, A.; POZZAN, T.; CARMIGNOTO, G. Intracellular calcium oscillations in astrocytes: a highly plastic, bidirectional form of communication between neurons and astrocytes in situ. J. Neurosc., v. 17(20), p. 7817-7830, 1997.

PAXINOS, G.; ASHWELL, K. W. S.; TORK, I. Atlas of the developing rat nervous system. 2. ed. Sydney: Academic Press, 1998. 1136 p.

PEREA, G.; ARAQUE, A. () Properties of synaptically evoked astrocyte calcium signal reveal synaptic information processing by astrocytes. J. Neurosc., v. 25 (9), p. 2192-2203, 2005.

PERSSON, L.; HARDEMARK, H.; EDNER, G.; RONNE, E.; MENDELHARTVIG, I.; PAHLMANN, S. S100 protein in cerebrospinal fluid of patients with subarachnoidal haemorrhage: a potential marker auf brain damage. Acta Neurochim., v. 93, p. 116-122, 1988.

PERSSON, L.; HARDEMARK, H. G.; GUSTAFSSON, J.; RUNDSTROM, G.; MENDEL-HARTVIG, I.; ESCHER, T.; PAHLMANN, S. S100 protein and neuronspecific enolase in cerebrospinal fluid and serum: markers of cell damage in human central nervous system. Stroke, v. 18, p. 911-918, 1987.

PETITO, C. K.; MORGELLO, S.; FELIX, J. C.; LESSE, M. L. The two patterns of reactive astrocytosis in postischemic rat brain. J. Cer. Blood Flow Metab., v. 10, p.850-859, 1990.

PETROVA, A.; MEHTA, R. Near-infrared spectroscopy in the detection of regional tissue oxygenation during hypoxic events in preterm infants undergoing critical care. Pediatri. Crit. Care Med., v. 7, n. 5, p. 449-454, 2006.

PIXLEY, S. K. e DE VELLIS, J. Transition between radial glia and mature astrocytes studied with a monoclonal antibody to vimentin. Dev. Brain Res., v.15, p. 201-209, 1984.

POWELL, FL.; MILSOM, WK.; MITCHELL, GS. Time domains of the hypoxic ventilatory response. Respir. Physiol., v. 112, p. 123-134, 1998. 
RAKIC, P. Neuron-glia relationship furing granule cell migration in developing cerebellar cortex. A golgi and electron microscopic study in Macacus rhesus. J. Comp. Neurol., v. 141, p. 283-312, 1972.

RAMÓN Y CAJAL S. L'Histologie du système nerveux de l'homme et de vertébrés. Madrid: Instituto Ramón y Cajal, 1972. v.1.

REEVES, R. H.; YAO, J.; CROWLEY, M. R.; BUCK, S,; ZHANG, X.; YAROWSKY, P.; GEARHART, J. D.; HILT, D. C. Astrocytosis and axonal proliferation in the hippocampus of $\mathrm{S} 100 \beta$ transgenic mice. Proc. Natl. Acad. Sci. USA, v. 91, p. 5359-5363, 1994.

RICKMANN, M.; AMARAL, D. G.; COWAN, W. M. Organization of radial glial cells during the development of the rat dentate gyrus. J. Comp. Neurol., v. 264, p. 449-479, 1987.

ROGALSKA, J.; CAPUTA, M.; WENTOWSKA, K.; NOWAKOWSKA, A. Stressinduced behavior in adult and old rats: effects of neonatal asphyxia, body temperature and chelation of Iron. J. Physiol. Pharmacol., v. 57, n. 8, p. 17-34, 2006.

ROGALSKA, J.; CAPUTA, M.; WENTOWSKA, K.; NOWAKOWSKA, A. Stressinduced behaviour in juvenile rats: effect of neonatal asphyxia, body temperature and chelation of iron. Behav. Brain Res., v. 154, p. 321-329, 2004.

ROSEN, H.; ROSENGREN, L.; HERLITZ, J.; BLOMSTRAND, C. Increased serum levels of the $\mathrm{S} 100$ protein are associated with hypoxic brain damage after cardiac arrest. Stroke, v. 29, p. 473-477, 1998.

ROTHERMUNDT, M.; PETERS, M.; PREHN, J. H. M.; AROLT, V. S100 $\beta$ in brain damage and neurodegeneration. Microsc. Res. Tech., v. 60, p. 614-632, 2003.

ROTHERMUNDT, M. Intracellular and extracellular roles of $\mathrm{S} 100$ proteins. Microsc. Res. Tech., v. 15, 60(6), p. 540-51, 2003. Review.

SCHARFMAN, $\mathrm{H}$. The CA3 "blackprojection" to the dentate gyrus. Progr. Brain Res., v. 163, p. 627-637, 2007. 
SCHAFER, B. W.; HEIZMANN, C. W. The S100 family of EF-hand calciumbinding proteins: functions and pathology. Trends Biochem. Sci., v. 21, p. 134-140, 1996.

SCHIFFER, D.; GIORDANA, M. T.; MIGHELI, A.; GIACONE, G.; PEZZOTTA, S.; MAURO, A. Glial fibrillary acidic protein and vimentin in the experimental glial reaction of the rat brain. Brain Res., v. 374, p.110-118, 1986.

SCHLESSINGER, A. R.; COWAN, W. M.; SWANSON, L. W. The time of origin of neurons in Ammon's horn and the associated retrohippocampal fields. Anat. Embryol., (Berl) v. 154, p. 153-173, 1978

SELINFREUND, R. H.; BARGER, S. W.; PLEDGER, W. J.; VAN ELDIK, L. J. Neurotrophic protein $S 100 \beta$ stimulates glial cellproliferation. Proc. Natl. Acad. Sci. USA, v. 88, p. 3554-3558, 1991.

SERRANO, A.; HADDJERI, N.; LACAILLE, J. C.; ROBITAILLE, R. GABAergic network activation of glial cells underlies hippocampal heterosynaptic depression. J. Neurosc., v. 26, p. 5370-5382, 2006.

SHEIN, N. A.; GRIGORIADIS, N.; HOROWITZ, M.; UMSCHWIEF, G.; ALEXANDROVICH, A. G.; SIMEONIDOU, C.; GRIGORIADIS, S.; TOULOUMI, O.; SHOHAMI, E. Microglial involvement in neuroprotection following experimental traumatic brain injury in heat-acclimated mice. Brain Res., v. 1244 , p. 132-141, 2008.

SILVERTHORN, D. U. Fisiologia Respiratória. In: SILVERTHORN, D. U. Fisiologia humana: uma abordagem integrada. 2. ed. São Paulo: Manole, 2003, p. 497-535.

SLEZAK, M. e PFRIEGER, F. W. New roles for astrocytes: regulation of CNS synaptogenesis. Trends Neurosc., v. 26(10), p. 531-535, 2003.

SLOTKIN, T. A.; COWDERY, T. S.; ORBAND, L.; PACHMAN, S.; WHITMORE, W. L. Effects of neonatal hypoxia on brain development in the rat: Immediate and long-term biochemical alterations in discrete regions. Brain Res., v. 374, p. 63-74, 1986.

SLOVITER, R. S. Decreased hippocampal inhibition and a selective loss of interneurons in experimental epilepsy. Science, v. 235, p. 73-76, 1987. 
SORCI, G.; AGNELETTI, A. L.; BIANCHI, R.; DONATO, R. Association of $S 100 \beta$ with intermediate filaments and microtubules in glial cells. Biochimique Biophys. Acta, v. 1448, p. 277-289, 1998.

STANIMIROVIC, D. B.; BALL, R.; SMALL, D. L.; MURUGANANDAM, A. Developmental regulation of glutamate transporters and glutamine synthetase activity in astrocytes cultures differentiated in vitro. Int. J. Devl. Neurosc., v. 17 , p. $173-184,1999$.

STRATA, F.; COQ, J. O.; BYL, N.; MERZENICH, M. M. Effects of sensorimotor restriction and anoxia on gait and motor cortex organization: implications for a rodent model of cerebral palsy. Neuroscience, v. 129, n. 1, p. 141-156, 2004.

STROMBERG, I.; BJÖRKLUND, H.; DAHL, D.; JOMSSON, G.; SUNDSTRÖM, E.; OLSON, L. .Astrocytes responses to dopaminergic denervations by 6hydroxydopamine and 1-methyl-4-phenyl-1,2,3,6-tetrahydropyridine as evidence by glial fibrillary acidic protein immunohistochemistry. Brain Res. Bull, v. 17, p. 225-236, 1986.

SWEDLOW, D. B. Review of evidence for a fetal SpO2 critical threshold of 30\%. Nellcor Puritan Bennett Perinatal Note, v. 2, p. 1-9, 1997.

TAKADA, S. H. "Efeitos da anoxia neonatal no encéfalo de ratos: estudo da distribuição de neurônios imunorreativos a Fos". 2009. 114 f. Dissertação (Mestrado em Ciências Morfofuncionais) - Instituto de Ciências Biomédicas, Universidade de São Paulo, São Paulo.

TAKADA, S. H.; SAMPAIO, C. A. G.; ALLEMANDI, W.; ITO, P. H.; TAKASE, L. F.; NOGUEIRA, M. I. Animal Model of neonatal anoxia: Development and Efficiency Evaluation by pulse oximetry, arterial gasometry and Fos immunoreactivity. J. Neurosci. Meth., 2011.

TAKANO, T.; KANG, J.; JAISWAL, J. K.; SIMON, S. M.; LIN, J. H.; YU, Y.; LI, Y.; YANG, J.; DIENEL, G.; ZIELKE, H. R. et al. Receptor-mediated glutamate release from volume sensitive channels in astrocytes. Proc. Nat. Acad. Science USA, v. 102(45), p. 16466-16471, 2005.

TAKAMIYA, Y.; KOHSAKA, S.; TOYA, S.; OTANI, M.; TSUKUDA, Y. Immunohistochemical studies on the proliferation of reactive astrocytes and the expression of cytoskeletal proteins following brain injury. Dev. Brain Res., v.38, p.201-210, 1988. 
TANG, A. C. e NAKAZAWA, M. Neonatal novelty exposure ameliorates anoxiainduced hyperactivity in the open field. Behav. Brain Res., v. 163, p. 1-9, 2005.

TIAN, G. F.; AZMI, H.; TAKANO, T.; XU, Q.; PENG, W.; LIN, J.; OBERHEIM, N.; LOU, N.; WANG, X.; ZIELKE, H. R. et al. An astrocytic basis of epilepsy. Nat. Med., v. 11(9), p. 973-981, 2005.

TRAMONTINA, F.; LEITE, M. C.; GONÇALVES, D.; TRAMONTINA, A. C.; SOUZA, D. F.; FRIZZO, J. K.; NARDIN, P.; GOTTFRIED, C.; WOFCHUK, S. T.; GONÇALVES, C. A. High glutamate decreases $\mathrm{S100b}$ secretion by a mechanism dependent on the glutamate transporter. Neurochem. Res., v. 31, p. 815-820, 2006.

TREMPER, K. K.; BARKER, S. J. Pulse oximetry. Anesthesiology, v. 70 (1), p. $98-108,1989$.

UEDA, S.; KOKOTOS, LEONARDI e BELL, J. III.; AZMITIA, E. C. Serotonergic sprouting into transplanted $C-6$ gliomas is blocked by $S-100 \beta$ antisense gene. Mol. Brain Res., v. 29, p. 365-368, 1995.

VAN ELDIK, L. J.; CHRISTIE-POPE, B.; BOLIN, L. M.; SHOOTER, E. M.; WHETSEEL JR, W. O. Neurotrophic activity of S-100 $\beta$ in cultures of dorsal root ganglia from embryonic chick and fetal rat. Brain Res., v. 542, p. 280-285, 1991.

VIZEK, M.; PICKET, C. K.; WEIL, J. V. Biphasic ventilatory response of adult cats to sustained hypoxia has central origin. J. Appl. Physiol., v. 63, p. 16581664, 1987.

VOLPE, J. J. Perinatal hypoxic-ischemic brain injury: overview. In Y. Fukuyama, Y.; Suzuki, S.; Kamoshita and P. Casaer (Eds.), Fetal Perinatal Neurol., p. 232-252, 1992.

VOLTERRA, A. e MELDOLESI, J. Astrocytes, from brain glue to communication elements: the revolution continues. Nat. Rev. Neurosci., v. 6(8), p. 626-640, 2005.

WAINWRIGHT, M. S.; CRAFT, J. M.; GRIFFIN, S. T.; MARKS, A.; PINEDA, J.; PADGETT, K. R.; ELDIK, V. Increased Susceptibility of S100B Transgenic Mice to Perinatal Hypoxia-Ischemia. Ann. Neurol., v. 56, p. 61-67, 2004. 
WEST, M. J.; KAWAS, C. H.; STEWART, W. F.; RUDOW, G. L.; TRONCOSO, J. C. Hippocampal neurons in pre-clinical Alzheimer's disease. Neurobiol. Aging v. 25, p. 1205-1212, 2004.

WHITAKER-AZMITIA, P. M.; MURPHY, R.; AZMITIA, E. C. S100 protein is released from astroglial cells by stilmulation of $5-\mathrm{HT} 1$ a receptors. Brain Res., v. 528 , p. 155-158, 1990.

WHITAKER-AZMITIA, P. M. e AZMITIA, E. C. Stimulation of astroglial serotonin receptors produces culture media which regulates growth of serotonergic neurons. Brain Res., v. 11, 497(1), p. 80-5, 1989.

WIESMANN, M.; WANDINGER, K. P.; MISLER, S. R.; ECKHOFF, D.; ROTHERMUNDT, M.; AROLT, V.; KIRCHNER, H. Elevates plasma levels of S100b protein in schizophrenic patients. Biol. Psych., v. 45, p. 1511-1521, 1999.

WINNINGHAM-MAJOR, F.; STAECKER, J. L.; BARGER, S.W.; COATS, S.; VAN ELDIK, L. J. Neurite expension and neuronal survival activities of recombinant $S 100 \beta$ proteins that differ in the content and position of cysteine residues. J. Cell Biol., v. 109, p. 3063-3071, 1989.

ZIMMER, D. B.; CORNWALL, E.H.; LANDAR, A.; SONG, W. The S-100 protein family: history, function, and expression. Brain Res. Bull., v. 37, p. 417-429, 1995. 